\title{
The development of carbon capture and storage (CCS) in India: A critical review
}

Rohit Shaw, Soumyajit Mukherjee*

Department of Earth Sciences, Indian Institute of Technology Bombay, Powai, Mumbai, Maharashtra, INDIA

*Author for correspondence: soumyajitm@gmail.com, smukherjee@ iitb.ac.in

\section{Statement:}

This article is a non-peer reviewed preprint, submitted to EarthArXi. The article has been submitted to the journal Carbon Capture Science \& Technology for peer review. 


\begin{abstract}
Carbon capture and sequestration (CCS) is a three-tier process- carbon capture, transport and storage. The capture consists of pre-combustion, oxy-combustion and post-combustion capture. Transport of $\mathrm{CO}_{2}$ is most viable through pipelines. The biotic $\mathrm{CO}_{2}$ storage occurs through terrestrial or oceanic pathways and can be simulated naturally or artificially. The abiotic/geologic storage is achieved through sequestering $\mathrm{CO}_{2}$ in depleting/depleted hydrocarbon reserves, in deep saline aquifers or through mineral carbonation. At the district level, 64 out of 641 districts (2013 government reports) accounted for $\sim 60 \%$ of the total $\mathrm{CO}_{2}$ emissions. Controlling $\mathrm{CO}_{2}$ emissions comes with the challenge of sustainable socio-economic growth of the country- a demanding task for the economy. Indian organizations have made international collaborations. India holds a substantial geological sequestration potential in its basaltic rocks, coal seams, depleted oil reserves, soils, deep saline aquifers and sedimentary basins. At this point, no carbon capture and storage / clean development mechanism projects are operational in the country. The next 10-15 years would be very crucial for India to attain technological advancement to deploy large-scale CCS projects.
\end{abstract}

\title{
Words: 173
}

Keywords: Environment management; pollution; technological measures; air quality; geology 


\section{Highlights:}

I. CCS process and terminologies summarised

II. Indian scenario in CCS elucidated, supported with case studies of promising technologies

III. Next decade will be crucial for India's CCS operation to initiate and succeed

\section{Introduction}

The increasing energy consumptions of the world are largely met by burning fossil fuels. According to British Petroleum (2020), 84\% of these consumptions consist of fossil fuel-based energy. The world consensus is in support of renewable energy. By the end of 2019, 28 countries issued climate change mitigation declarations, the majority of which included plans for transition to renewable energy (REN21 2020).

In spite of these, various barriers remain in the adoption of renewable energy. Several social, economic, technological and regulatory barriers hinder the adoption of renewable energy (Seetharaman et al. 2019). This is a pressing concern from ecologic and environmental perspectives as coal combustion is a chief source of $\mathrm{CO}_{2}$. Burning of fossil fuels releases $\mathrm{CO}_{2}$. Outgassing of $\mathrm{CO}_{2}$ during the snowball Earth event 800-600 My ago (Crowley et al. 2001) warmed the climate after the snowball phase by trapping solar energy that presumably favoured the first multi-cellular life on the Earth (Hyde et al. 2000). An appropriate concentration of $\mathrm{CO}_{2}$ 
in the atmosphere is extremely essential for life on Earth. $\mathrm{CO}_{2}$ concentration plays an important part in photosynthesis, which in turn drives the food chain on the Earth. But excess of anything turns hostile- and that has been happening with the atmospheric $\mathrm{CO}_{2}$ whose concentration has well exceeded the maximum limit of $~ 350$ ppm (Hansen et al. 2008).

Till the industrial revolution, anthropogenic carbon production mainly from wood-burning and other sources were at equilibrium with natural carbon uptake processes e.g., photosynthesis and ocean-atmosphere carbon flux. However, the situation changed after the 1780s with the industrial revolution. It is estimated that since then $\sim 15-40 \%$ of additional anthropogenic carbon emissions happened. These excess emissions would continue to be in the atmosphere for at least a millennium and would take thousands of years to be removed by natural processes alone (Harde 2017).

The present-day concentration of $\mathrm{CO}_{2}$ in the atmosphere is responsible for $26 \%$ of the global warming (Bhui 2021). On the other hand, the global energy demand is predicted to double by 2030 with the majority of it being met with fossil fuel sources, because of their low-cost and the existing infrastructures. This would cause the global mean temperature to rise by $2{ }^{\circ} \mathrm{C}$ by 2065 (Lau et al. 2021) against the Intergovernmental Panel on Climate Change (IPCC) target of limiting global temperature rise to $2^{\circ} \mathrm{C}$ by 2100 (Paris Agreement, 2015; Bui et al. 2018). To achieve the Paris agreement goal, by 2050 the emissions would need to be cut by $50-80 \%$ from the 1990 levels. The Agreement was a successor to other such assents, viz., Geneva Convention (1979), Montreal Protocol (1987), Kyoto Protocol (1997) and the Doha amendment (2012) (Yoro 
and Daramola 2020; Table S1). The international energy bodies have targeted to make half the $\mathrm{CO}_{2}$ emission due to energy production by 2050 (Haszeldine 2009; Lu et al. 2020).

\subsubsection{General points}

Increasing temperatures have made the Earth vulnerable to several issues such as the sea-level rise and associated issues of coastal erosion, flooding, saline water intrusion and infrastructural damages (Nazarnia et al. 2020). Extreme weather conditions such as increased frequency of cyclones (Knutson et al. 2010), flood, drought (Prospero et al. 2003; Gleick 2014) and forest fire (Flannigan et al. 2006) have also been noted in the recent years.

\subsubsection{Atmospheric $\mathrm{CO}_{2}$ levels}

Atmospheric $\mathrm{CO}_{2}$ level over the last 300 years has changed rapidly. The timeframe ranging from 1780s till the present has seen the most incredible and life-changing developments. The levels of $\mathrm{CO}_{2}$ changed drastically to over $100 \mathrm{ppm}$ within $\sim 250$ years. Whereas the pre-1750 level lingered at $280 \mathrm{ppm}$ (Wigley1983), the current level exceeded $400 \mathrm{ppm}$, much above the accepted limit of 350 ppm (Azar and Rodhe1997). In the last decade, the atmospheric $\mathrm{CO}_{2}$ concentration has increased by $>2 \mathrm{ppm} \mathrm{y}^{-1}$ (Yoro and Daramola 2020). The current $\mathrm{CO}_{2}$ level stands at 413.08 ppm (14-Sept-2021, Mauna Loa Observatory, Hawaii).

In the geologic past, however, $\mathrm{CO}_{2}$ levels much exceeded this threshold and reached $4400 \mathrm{ppm}$ by natural means during the Triassic-Jurassic mass extinction (Schaller et al. 2011) characterized 
by extreme volcanism forming the Central Atlantic Magmatic Province (Blackburn et al. 2013).

Such values were mainly attributed to volcanic activity.

Currently, China accounts for maximum emission, $\sim 26 \%$ of the global emissions . For the USA, India and Russia, the emission percentages with respect to global values are 13.7, 7.0 and 4.8, respectively (Yoro and Daramola 2020).

\subsubsection{Consequences of the increasing atmospheric $\mathrm{CO}_{2}$ level}

Climate change has become a reality. The steady increase in sea-level and average global temperature is the outcome. Since 1880, the average temperature of the Earth has increased by $0.8^{\circ} \mathrm{C}$, which in turn rose the global mean sea at $\sim 1.7 \mathrm{~mm} \mathrm{y}^{-1}$, being $3.0 \mathrm{~mm} \mathrm{y}^{-1}$ since 1993 (Church et al. 2011; Dieng et al. 2017). The sudden spike since 1993 has been attributed to the rapid loss of the Greenland ice sheets (Chen et al. 2017). Rising sea levels and mean global temperature are the major repercussions of the rising atmospheric reservoir of $\mathrm{CO}_{2}$. A perpetual increase from the current levels will only result in severe consequences in future. Rising sea levels will submerge the highly populated coastal areas of the world (such as Bangladesh), leading to acute pressure on the existing land to host the ever-growing population that is expected to touch 9.6 billion by 2050 (Tripathi et al. 2019). Concentrated efforts need to be taken now if such hazardous projections must be nullified.

\subsubsection{Possible solutions}


As the world population grows, there will be a complementary increase in energy demand. The production of this energy will further add to the ever-increasing $\mathrm{CO}_{2}$ level of the atmosphere. Places such as Hong Kong, China and Singapore have already started transitioning to low-carbon transport options viz., electric rails and metro and discouraged the use of personal cars (Senthilkumar 2021).

This situation needs to be addressed fast in three possible ways (Figueroa et al.2008): (i) to opt for alternate sources of clean energy; (ii) reduce the intensity of $\mathrm{CO}_{2}$ production by focusing cleaner forms of combustion of the available fuel or to choose cleaner fuel (anthracite or bituminous) with high carbon-content; and (iii) focus on the development of efficient carboncapture and sequestration technologies.

India holds a sizeable share in the global growing energy demand, $69 \%$ of which are met through fossil fuels, out of which $44 \%$ is coal-based (IEA2020a). This seems viable since India has the third-largest coal reserve in the world. As on01-April-2019, the official figure stands at 326.05 BT, as measured up to a depth of 1200 m (GOI 2020a). Projections indicate that India's emission could stand at around 5.6 BT in the business-as-usual scenario when as per India's Intended Nationally Determined Contributions (INDC), non-fossil fuels would contribute to $40 \%$ of its total electricity installed capacity (Section 3.3). India will probably account for $\sim 25 \%$ of the increased energy demand from 2017 and 2040. Coal-based energy would meet $\sim 42 \%$ of the incremental demands (Ray 2021). These trends indicate that fossil fuel will be continued to be used as a power source well into the 2040s, with projected emissions reaching their peak in 2043 
(Frank 2015). An average $500 \mathrm{MW}$ thermal power plant can emit 2-3 $\mathrm{MT} \mathrm{CO}_{2}$ annually (Yoro and Daramola 2020) and coal-based energy generation is slated to be in the range of $330-441$ GW in 2040, increasing from $175 \mathrm{GW}$ in 2017 (Goel et al. 2021b).

In such a global and Indian scenario, the only method, besides using clean energy sources and policy interventions, is carbon capture and sequestration (CCS; Yoro and Daramola 2020). Fig. 1 portrays carbon cycle with and without sequestration. Leung et al. (2014) has summarized $\mathrm{CO}_{2}$ reduction strategies. Meeting the net-zero emission target within this century is impossible without CCS (GCCSI 2020). An estimate by the IEA state that to meet the Paris agreement goals, an additional investment of USD 9.7 trillion, by 2050 would be required in Carbon capture, utilisation and storage (CCUS) deployment (IEA 2019). Wei et al. (2021) also estimated a similar number at USD 8.2 trillion as per the "global cost effective CCUS layout strategy". Moving ahead with IEA's estimatein absolute terms, this is almost 3.4 times the size of India's GDP. However, the cost of not implementing it (climate change-related disasters) far eclipses this value. Between 2000 and 2019, the global economy incurred a loss of USD 4.78 trillion. The last decade (2010-2019) saw the highest loss at USD 2.98 trillion. In the prior decade (2000 - 2009), the number was USD 1.8 trillion. There was an increase of USD 1.1 trillion in one decade (AON 2019). If we project from here, assuming no increase in decadal losses, the number stands at USD 13.72 trillion by 2050. If an increase of USD 1.1 trillion is factored in per decade, the losses stand at USD 17.02 trillion by 2050. In economic terms, an investment of USD 9.7 trillion to tackle a loss of USD 17.02 trillion seems feasible in the current context. Such investments also entail certain risks, especially the geological storage of $\mathrm{CO}_{2}$ (Section 2.4.3c). However, risk assessment studies involving the selection of sites, reservoir 
characteristics and monitoring of $\mathrm{CO}_{2}$ movement, in early stages as well as in simulation, have significantly decreased the possibility of such mishaps (global case) (Hardisty et al. 2011).

There are already commercial sites operating in Sleipner (Norway) and Gorgon (Australia) (Section 2.4.3b6, Fig. 2). CCS would also enable a "just transition", which would create new jobs in the net-zero industry, allowing re-use or continued use of available infrastructure and defer their shut-down costs (GCCSI 2021). Bergstrom and Ty (2017) analysed the total cost and benefit of CCS technologies and concluded that the private, public and social benefits of the technology in mitigating global warming outweigh its cost. Research on CCS in the previous decade present CCS as a critical option in tackling climate change (Bonto et al. 2021). Review by Seigo et al (2014) presents an all-round view of how the public is perceiving the CCS technology based on 13 variables. These variables are a part of Energy Technology Acceptance Framework (ETAF) developed by Huijts et al. (2012). The public opinion is weighed on the basis of acceptance, Knowledge, Experience, Trust, Fairness, Technologies Affect, Perceived Costs, Perceived Risks, Perceived Benefits, Outcome Efficacy and Problem Perception. However, there has not been a clear conclusion on what the majority seems to agree with due to lack of enough knowledge dissemination among the public. Such efforts, however, can be undertaken. 


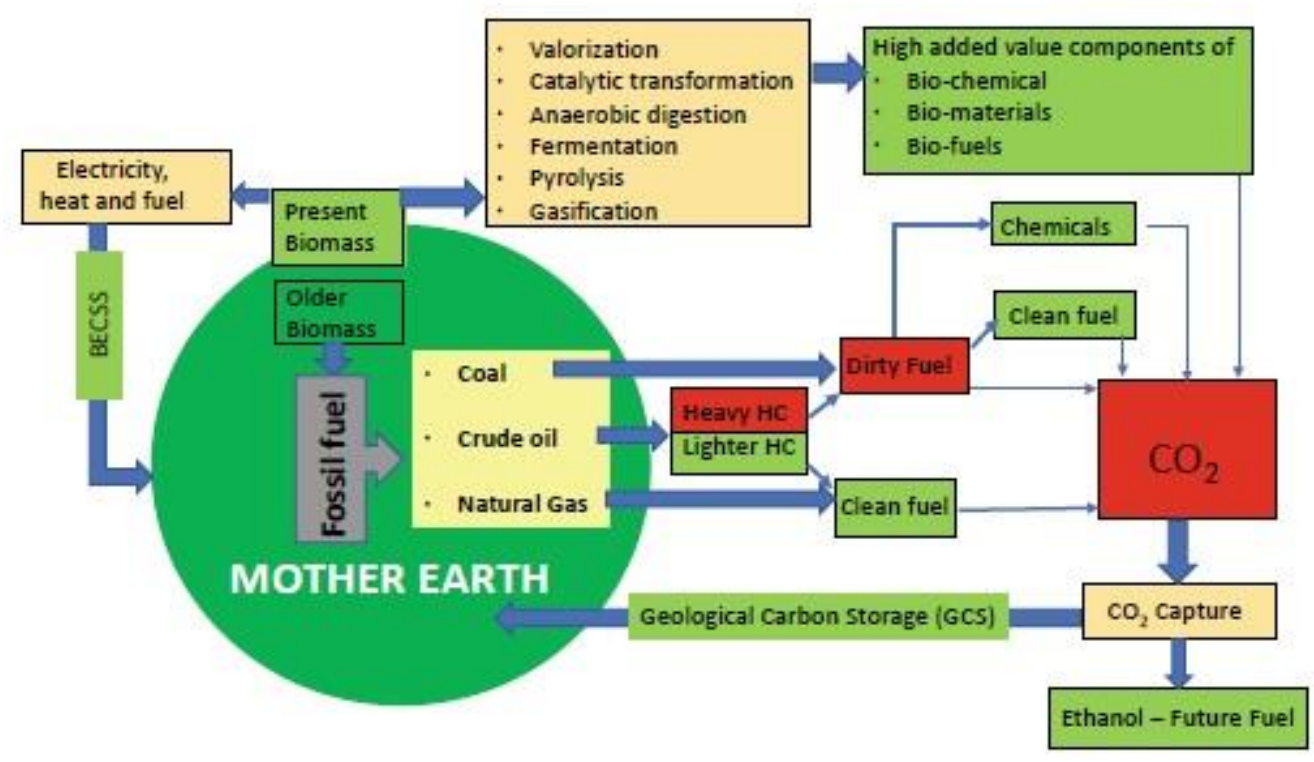

Fig 1. Carbon cycle with or without artificial sequestration (Reproduced from fig. 1 of Bhui et al 2021).

Smit et al. (2014) preferred recycling of $\mathrm{CO}_{2}$ over its sub-surface storage. Methanol production from captured $\mathrm{CO}_{2}$ holds a great prospect as a transportation fuel and in the petrochemical industry (Bhui 2021). However, at present, recycled products of $\mathrm{CO}_{2}$ utilized for the chemical industry cannot solve the problem of elevated $\mathrm{CO}_{2}$ concentration in the atmosphere.

Infrastructural dearth, capital and safety issues trouble carbon utilisation into fuels (Kanjilal et al. 2020). Section 4.1 presents some promising prospects. Arehart et al.'s (2021) review concluded that integration of carbon-based materials in buildings and construction can prove to be a safe sequestration option above ground.

CCS applied to an existing emitter will only act as a transition technologyfor its decarbonisation (Lau et al. 2021). CCS can decrease the carbon footprint of fuels by 90\% (Senthilkumar 2021). This will allow the use of fossil fuels until they are replaced by relatively cleaner energy sources (Table S2: advantages and disadvantages of other methods). It will be beneficial particularly for 
India being a coal-dependent country (GCCSI 2020). During 2003-04, efforts were made to explore the potential of supercritical and ultra-supercritical thermal power plants that have efficiency values of $\sim 44 \%$ and $\sim 50 \%$, respectively. This was to avoid old thermal power plants running at $<35 \%$ efficiency. Investments however were not made to install carbon capture technologies due to economic reasons (Donev et al. 2018; Verma 2021).

Currently, the global reality is different, and this becomes particularly important for 'hard-toabate' industries (Fig. S1: emission sources of hard-to-abate industries). These industries account for $20-30 \%$ of the global emissions and mainly consist of cement, petrochemical and steel industries. These industries heavily depend on fossil fuels as reducing agents (coal in iron and steel industries) and as a feedstock in their production (e.g., petroleum in petrochemical industries, calcium carbonate in cement industry; Leeson et al. 2017; IEA 2020b). Paltsev et el. (2021) concluded that with Industrial CCS technology deployment, the global cost for reaching the Paris target would be $12 \%$ less by 2075 and $71 \%$ less by 2100 , as opposed to without CCS options.

All these industries would primarily depend on post-combustion capture technology to reduce their emissions. Post-combustion capture allows retrofitting the existing infrastructure at the end of the cycle for carbon capture (Section 2.2.2). This technique also stands true for thermal power plants that are major emission sources in the power sector. Post-combustion capture can also increase the industrial production 3.7 to 7 times the 2010 levels by 2100 as opposed to meagre 1.6 times without such a capture (Paltsev et al. 2021). 
In the cement industry, $60-70 \%$ of $\mathrm{CO}_{2}$ is generated as process emissions during the clinker production [calcium carbonate $\left(\mathrm{CaCO}_{3}\right)$ breaks down into calcium oxide (clinker) and $\mathrm{CO}_{2}$ ], which account for $\sim 33 \%$ of emissions (IEA 2020b). For such industries, CCS seems to be the only viable option, besides technology upgradation e.g., clinker substituted by blast furnace slag and fly ash in the cement industry (Xavier and Oliveira 2021). Chemical looping combustion can reduce emission in the cement industry (Gu et al. 2015; Section 2.2.4). Hargis et al. (2021) developed a new $\mathrm{CaCO}_{3}$ cement using $\mathrm{CO}_{2}$-rich industrial flue gas, calcium and alkali. All the feedstocks essentially are industrial waste products, e.g., those of thermal power and acetylene production plants. Flue gas is produced in thermal power plants and acetylene production produces carbide lime sludgeas a waste product. This cement, which is completely manufactured using waste products of different industries (primarily $\mathrm{CO}_{2}$ ), has advantages over traditional cement such as lighter weight, shorter production cycles and similar compressive strength (> 40 $\mathrm{MPa})$ to traditional cements.

The iron and steel industries account for $\sim 31 \%$ of the industrial emissions. Out of this the blast furnace (where iron ore is smelted) emits $65-70 \%$ of the emissions, followed by coking coal plant (where coal converts to coke in the blast furnace, Ashour 2018) at 27\% and sinter plant (where iron ore dust is agglomerated and sent to the blast furnace) at 6\% (Pérez-Fortes et al 2014; Leeson et al 2017). The primary emission here comes from coal (in the form of coke) to reduce iron to a relatively pure form, which is further processed for making other products. Carbon capture technology can be retrofitted to these sources in a steel plant to capture $\mathrm{CO}_{2}$, reducing the emission of the plants. This can minimize emission causing reducing agents such as 
hydrogen, polymer/coke blends and lignin. However, these alternatives are in their initial stages of research. One type of hydrogen production itself depends on hydrogen, and polymer/coke blend is not a complete replacement as it still uses coke. Lignin is most promising, but its current production is too low to meet the demand (Sahajwalla et al. 2019).

The petrochemical industry accounts for $\sim 10 \%$ of the industrial emissions. Within them, the boilers and furnaces account for $\sim 65 \%$ of the emissions followed by gasifiers at $\sim 10 \%$ (Leeson et al. 2017). Petroleum alongside coal is a major driver of the industrial wheels. Replacing petroleum can only be done if there is an established alternative fuel source. There are few renewable options that are slowly gaining attention.

Worldwide petrochemical plants are high-value assets with certain economies completely dependent on them (e.g., Middle East, Russia; Snyder et al. 2020). The only option left then are CCS technologies that reduce the emission intensity of the petrochemical industry.

Post-combustion capture also stands true for the thermal power plants that are major emission sources in the power generation sector. Apart from post-combustion capture, pre-combustion capture technologies viz., IGCC, IRCC (Section 2.2.1) and oxy-combustion capture (Section 2.2.3) have considerable potential in decreasing the emission intensity of thermal power plants and at the same time allowing for a smooth transition to cleaner energy sources and more energyefficient plants. CCS retrofitting has the potential of bringing down the emissions of thermal power plants to nearly zero by 2047 (Vishal et al. 2021). 
As of 2020, there are 65 commercial CCUS facilities worldwide out of which 26 are operating, three are under construction, 13 are in advanced development, 21 are in early development and 2 have been suspended (Fig. 2; GCCSI 2020). Altogether, they sequester $40 \mathrm{MT}$ of $\mathrm{CO}_{2}$ annually. To put this into perspective, the global emissions in 2019 stood at 52 BT. If the total conversion rate remains intact, the existing plants will take 130 years to sequester, provided there are no further emissions. This is an impossible scenario and hence more such plants need to develop. A special report by IPCC (2018) reviewed 90 scenarios to restrict global warming to $1.5^{\circ} \mathrm{C}$. Together, they need to meet permanent sequestration of 10 BT by 2050 to attain the $1.5{ }^{\circ} \mathrm{C}$ target. The current sequestration potential is thus rendered extremely insufficient. Around 2000 CCS plants are required to meet the IPCC targets decided in the Paris Summit (Senthilkumar 2021).
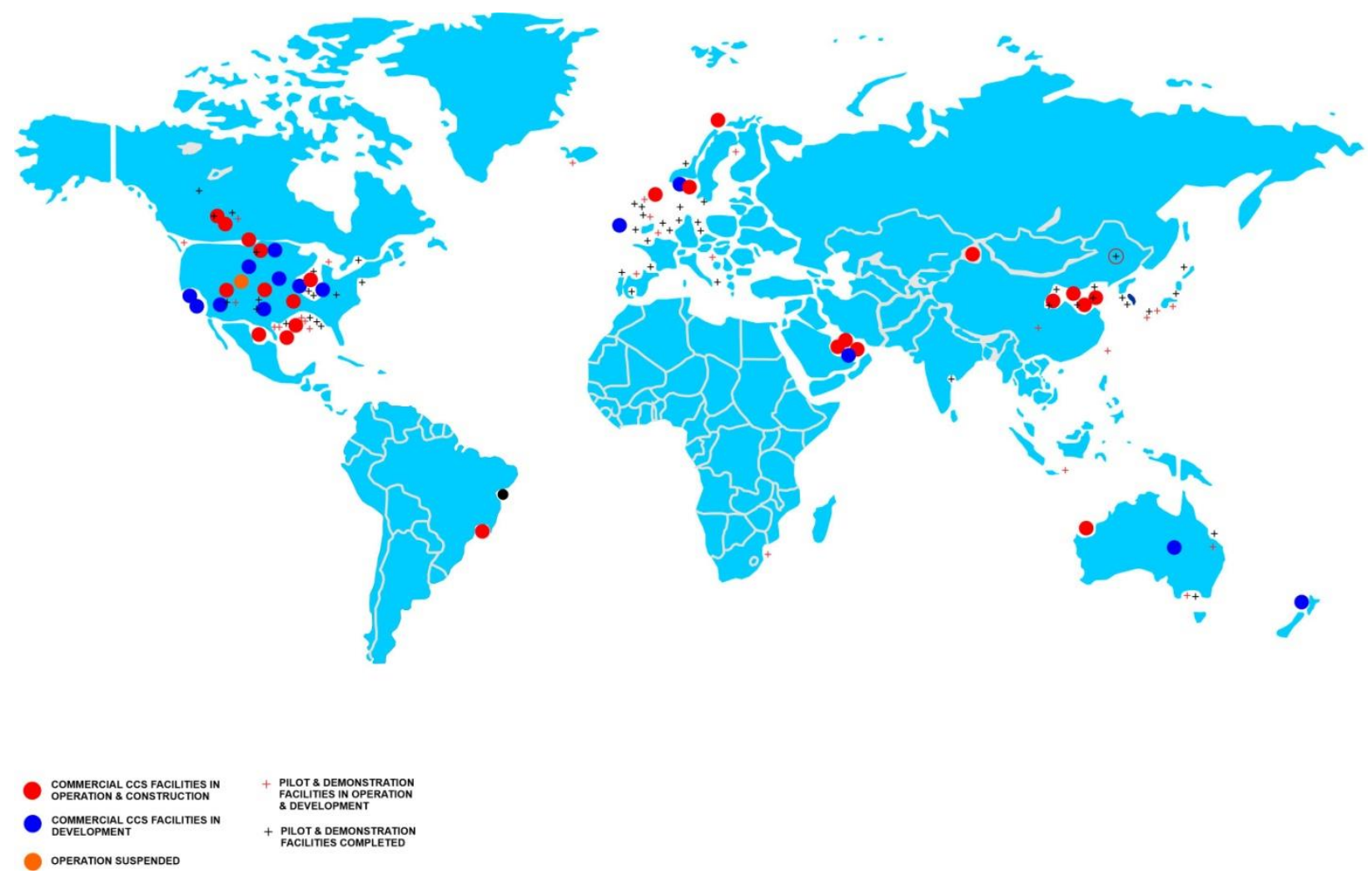
Fig 2. A world map showing the different CCS facilities at different stages of operation (reproduced from fig. 5 of GCCSI 2020).

In this context of the $\mathrm{CO}_{2}$ dilemma, this article provides an overview of CCS with the primary focus on reviewing the potentials, technologies, and current scenarios in the Indian CCS arena. Goel (2008) presented CCS studies from the Indian perspective. However, in the last 13 years, numerous advancements have taken place in the field, therefore an updated review article was needed. We also discuss few case studies to provide promising technologies and feasibility studies that hold huge potential in bringing India onto the global CCS map. We describe the prospects of CCS in India. We understand that each sub-section in this article has the potential to develop as standalone contributions.

\subsection{Contents of this review article}

In this article, Section 1 briefly introduces the current energy situation in India and the world, the trend of $\mathrm{CO}_{2}$ increase, its consequences, and importance of CCS- and especially the present Indian scenario. Section 2 elucidates CCS- its various components, techniques, and technologies. Section 3 is an overview of India's carbon footprint, its trend over the years and emission hotspots of the country. The section concludes with India's emission projections in the coming decade and the effect of Covid-19 in the temporary thwarting of emissions. Section 4 elaborates the need for carbon sequestration in India along with major research and developments in this century. This is followed by the sequestration potential of India in biotic and abiotic means. Section 5 presents few Indian case studies that hold significant potential for carbon sequestration if scaled-up. Section 6 describes the prospects in terms of CCS-CDM and ACT proposals. 
Section 7 concludes the review by mentioning a probabilistic timeline for the deployment of CCS in India.

\section{Carbon sequestration}

\subsection{General points}

The history of carbon sequestration goes back to the 1920 s when $\mathrm{CO}_{2}$ was separated from the natural gas in the gas wells. Soon it was realised that the captured gas can augment the process of oil extraction. The process came to be known as the Enhanced Oil Recovery (EOR), which gained momentum in the 1970s and the 1980s (Gupta and Paul 2019). This process also locked down captured $\mathrm{CO}_{2}$ into those geologic formations from where oil was extracted, not allowing it to add to its global atmospheric reservoir (IEAGHG 2013). $\mathrm{CO}_{2}$-EOR reduces the viscosity of oil thereby enhancing its extraction by $\sim 43 \%$ (Liu et al. 2019), while in some studies the extraction enhancement was 10-22\% (Karmakar 2016). However, the claim that it enhances the extraction rate is irrefutable. Currently, there are $18 \mathrm{CO}_{2}$-EOR projects worldwide (Fig. 2), out of which six operate on $\mathrm{CO}_{2}$ obtained from power plants (Elmabrouk et al. 2017).

Carbon sequestration is a three-tier process (Feron and Hendricks 2005): ( $i$ ) carbon capture from emission plants or directly from the air; (ii) conversion into suitable forms to be transported and deposited to sequestration sites; and (iii) the final sequestration of the carbon. 


\subsection{Carbon capture}

The most important procedure is to capture carbon from flue gases (other methods in Fig.

S2).There are three pathways: (i) pre-combustion capture, (ii) oxy-combustion capture; and (iii) post-combustion capture (Padurean et al. 2012; Jain et al. 2016).

\subsubsection{Pre-combustion capture}

As the name suggests, $\mathrm{C}$ is captured, in form of $\mathrm{CO}_{2}$, before the fuel combusts. Two leading technologies that make this happen are Integrated Gasification Combined Cycle (IGCC) and Integrated Reformed Combined Cycle (IRCC; Lorenzo et al. 2013). In the latter, a syngas production process called auto-thermal reforming (Shahhosseini et al. 2017) is combined with a cycle power generation plant. In the former case, a gasification process is combined with the combined cycle power generation plant (Di Lorenzo et al. 2013).

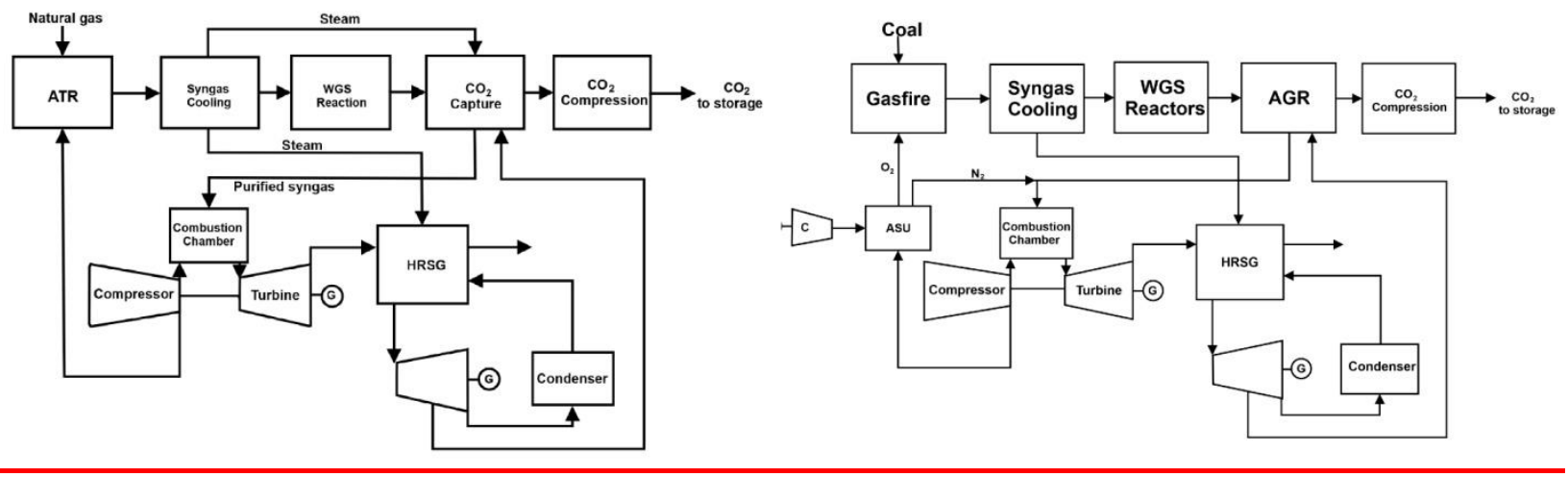

Fig. 3(a) Left figure. a schematic diagram of IRCC. Reproduced from fig. 1 of Di Lorenzo et al. (2013). (b) Right figure. A schematic diagram of IGCC. Reproduced from fig. 2 of Di Lorenzo et al. (2013). 
In a typical IRCC (Fig. 3a), there is an Auto-thermal reformer (ATR), two Water-Gas shift (WGS) reactors, one pre-reformer, and a single $\mathrm{CO}_{2}$ capture section. The heavy hydrocarbons e.g., ethane, butane and propane (Mokhatab et al. 2012) in the natural gas are converted to $\mathrm{CO}_{2}$ and $\mathrm{H}_{2}$. Following this, the natural gas is converted into syngas (mainly containing $\mathrm{CO}, \mathrm{CO}_{2}$ and $\mathrm{H}_{2}$ ) in the ATR. The syngas undergoes the WGS reaction in the WGS reactor, by converting CO into $\mathrm{CO}_{2}$. The heat produced during the process is added to the Heat-Recovery Stream Generator (HRSG), to remove the heat and generate steam. $\mathrm{CO}_{2}$ is liquified and stored, resulting in a carbon-free fuel (Nord et al. 2009; Di Lorenzo et al. 2013).

IGCC is a coal-driven power generation technology that is more efficient and environment friendly than a typical coal-powered plant (Emun et al. 2010). It leads to a substantial decrease in the release of pollutants and can be a useful retrofitting option for existing thermal power plants (Yoro and Daramola 2020). In IGCC, coal is decarbonised before combustion. Just as the natural gas is used as an input in IRCC, in IGCC, inputted coal or other carbon-based feeds such as coke etc. under pressure reacts with $\mathrm{O}_{2}$ and steam to generate the syngas (Fig $3 b$ ). The $\mathrm{O}_{2}$ is supplied by the Air separation unit (ASU). Steam is added to the syngas in the WGS reactor after the syngas passed through the syngas cooling section. Heat generated from the cooling section is added to the HRSG (like IRCC). The acid gases removal (AGR) section removes the acid gases from the syngas. The resultant $\mathrm{CO}_{2}$ is captured, and $\mathrm{H}_{2}$-rich fuel is obtained. This $\mathrm{H}_{2}$ is called "blue hydrogen" as opposed to "greyhydrogen" when no carbon capture takes place and "green hydrogen" when water is electrolysed, using renewable energy, to obtain hydrogen (Kanniche and Bouallou 2007; Descamps et al. 2008; Gibbins and Chalmers 2008; Di Lorenzo et al. 2013; Wood 2020). 


\subsubsection{Post-combustion capture}

Post-combustion capture involves the capturing of carbon from the flue gas generated at plants concerned with the burning of fossil fuels. It is the only process that is industrially employed, which can be seen in TMC Mongstad (0.3 million tonnes $\left.\mathrm{y}^{-1}\right)$ and BD3 SaskPower (1 million tonne $\mathrm{y}^{-1}$ ) in Norway and Canada, respectively (Liang et al. 2015). It is also the most widely researched and adaptable method, with various technologies being used for it e.g., solvent-based absorption, membrane-separation, mineralization, adsorption-driven, cryogenic capture and microalgae-based carbon capture (Mokhtar et al. 2012; Kanjilal et al. 2020). Amongst solventbased PCC, amine-based solvents are widely used. Monoethanolamine (MEA) is most widely used for its high- $\mathrm{CO}_{2}$ reactivity and high capture efficiency ( 90\%) (Kanjilal et al. 2020). Membranes are semi-permeable structures that separate $\mathrm{CO}_{2}$ from the gaseous mixtures emitted out after fuel combustion (Carrera et al. 2017). Membrane-based PCC is significantly advantageous in high surface area, considerably reducing the equipment size and increasing the efficiency. Polytetrafluorethylene (PTFE) is the most widely used PCC membrane in many pilot studies. However, it has still not been used in industry (Zhao et al. 2016) presumably because of its high cost and further research is underway (Merkel et al. 2010). The process of mineralization is mineral carbonation where $\mathrm{CO}_{2}$ is converted into stable carbonates for their storage, especially in areas that lack suitable geological formations (Zevenhoven and Fagerlund 2009). It is also a process of storage as opposed to the other three that deal with only carbon capture and is more environment-friendly than geologic sequestration (Helwani et al. 2016). Hence Section 2.4.3c details mineral carbonation. Adsorption is a process of $\mathrm{CO}_{2}$ capture by making it interact with a solid (molecular sieves or activated carbon) or chemical adsorbent such as modifying low-cost 
carbons using polyethyleneimine (Drage et al. 2009). In the last few decades, ionic solvents have been found to be better adsorbent than the other media (Das et al. 2021). Ionic liquids provide several advantages over other methods due to easy regeneration, low solvent loss and low environmental impact (Farsi and Soroush 2020; Fig. S3- detailed classification of ionic liquids). Nanomaterials such as nanomembranes, nanoparticles and nanosheets are gaining worldwide acceptance as adsorbents (Pant et al. 2021). Other materials such as activated carbon, zeolites, amine-functionalized silica, porous organic frameworks and metal organic frameworks (MOFs) (subcategories of MOFs include MOF-glass membranes, MOF-Covalent organic frameworks membranes, MOF based mixed matrix membranes)(Demir et al. 2022) are also expanding the range of adsorbent materials for post-combustion capture (Siegelman et al. 2021). Biochar based adsorbents also have potential due to their wide availability, low cost, renewable nature and highly porous structure (Qiao and Wu 2022). (MOFs Cryogenic capture involves lowering the temperature of flue gas and separating the solidified $\mathrm{CO}_{2}$ from the flue gas (Ahuja 2021; Table S3). Review by Buckingham et al. (2022) shows that process intensification can be used by integrating the $\mathrm{CO}_{2}$ adsorbtion process into the chain of reactions that generate $\mathrm{CO}_{2}$. This can have advantages in terms of increased energy efficiency.Section 2.4.4. discusses capture (and sequestration/utilization) through microalgae. There are several other methods that are under research (Fig. S4).

\subsubsection{Oxy-combustion capture}

Here there is no real 'capture' of $\mathrm{CO}_{2}$. The fossil fuel itself is burnt in an oxygen-rich environment thus allowing for a cleaner and fuller combustion of the fossil fuels, greatly reducing the $\mathrm{CO}$ and the $\mathrm{SO}_{2}$ contents (Jain et al. 2016). The process does not involve any 
membranes or absorbents and is thus significantly cost-effective for new plants, but the cost increases if old plants are retrofitted. Review by Yadav and Mondal (2022) concludes that the overall cost of carbon capture is less in Oxy-combustion capture. Another advantage is that almost pure (90\%) $\mathrm{CO}_{2}$ can be directly compressed and stored without the need for further purification as in PCC (Gopan et al. 2014; Jain et al. 2016).

The challenges of this technology are primarily related to retrofitting an old plant which are caused by high temperatures during combustion and air that leaks into the system. These factors negatively affect performance (Yadav and Mondal, 2022).

\subsubsection{Chemical looping Combustion (CLC)}

The technologies discussed in Sections $2.2 .1-2.2 .3$. involve a high energy penalty $(\sim 15 \%)$, which decreases the efficiency of the system. In the above cases, a significant amount of energy is spent to separate and obtain a pure stream of $\mathrm{CO}_{2}$ that is further stored or processed. Chemical Looping Combustion (CLC) is a cost-effective alternative to other methods (Kumar and Parwani 2021).

CLC uses a metal oxide as an oxygen source (Jain et al. 2016). The looping, as the method is named, is between two chambers: oxidation and reduction. In the oxidation chamber, also called the air reactor, a metal is oxidised in air to obtain its oxide. This metal oxide acts as an oxygen carrier that reacts with fuel (any hydrocarbon $\mathrm{C}_{\mathrm{x}} \mathrm{H}_{\mathrm{y}}$ ) in the reduction chamber, also called the fuel 
reactor (Lisbona et al. 2020). The metal oxide $\left(\mathrm{Me}_{\mathrm{x}} \mathrm{O}_{\mathrm{y}}\right)$ is reduced to its metal form (Me), $\mathrm{CO}_{2}$ and $\mathrm{H}_{2} \mathrm{O}$. The reduced metal is again looped into the oxidation chamber where the process resumes. The pure $\mathrm{CO}_{2}$ stream from the reduction chamber can be compressed for storage, transportation or utilisation. This significantly reduces the cost of obtaining $\mathrm{CO}_{2}$ from flue gas. The primary roadblock in this method is the metal that is used for continuous cycling without much physical and chemical degradation. Another concern is the energy required for cycling solid metal between the chambers. As of now, there are no operating facilities employing this technology anywhere in the world (Verma et al. 2015; Jain et al. 2016; Kumar and Parwani 2021). Table 1 summarizes the technologies discussed above.

Table 1. Advantages and disadvantages of $\mathrm{CO}_{2}$ capture process summarised (modified from table 2 of Leung et al. 2014).

\begin{tabular}{ccc}
\hline Process & Advantages & Disadvantages \\
\hline Pre-combustion & $\begin{array}{c}\text { High } \mathrm{CO}_{2} \text { concentration that increases } \\
\text { absorption efficiency }\end{array}$ & $\begin{array}{c}\text { Fewer experience in } \\
\text { actual industrial usage. }\end{array}$ \\
Post-Combustion & $\begin{array}{c}\text { Most developed capture technology with } \\
\text { relatively easier retrofitting options to } \\
\text { existing plants }\end{array}$ & Low capture efficiency \\
Oxy-combustion & Produces high concentration of $\mathrm{CO}_{2}$ \\
& $\begin{array}{c}\text { Qllowing efficient capture efficiencies. } \\
\text { Quite cost effective for new plants }\end{array}$ & Costly during retrofits. \\
& Cost effective alternative. Can provide a \\
clear stream of $\mathrm{CO}_{2}$ that can be & Technology still in its \\
chempressed and stored & development phase \\
& & \\
& &
\end{tabular}

\subsection{Transportation}


The carbon capture is followed by its transportation from the point of capture to the point of its final sequestration. The captured carbon is compressed to liquefy itself, to smoothen its transportation process. After liquefaction, the most convenient way to transport it is through pipelines. However, small shipments of few tonnes are also transported through trucks over short inland distances- from large point sources to ports for further transport via ships. Ships are already transporting 1000 tonnes of food-quality $\mathrm{CO}_{2}$, in Europe (GCCSI2012). However, shipments of small quantities would not be viable if the large-scale prospect of carbon sequestration is considered. Pipelines are the most suitable means to transport $\mathrm{CO}_{2}$ in the scale of the current requirement and have been conveniently in business since $1970 \mathrm{~s} . \mathrm{CO}_{2}$ is moved in a supercritical phase under high pressure. This dense phase $\mathrm{CO}_{2}$ is prone to gradient changes and contamination. This requires specific and continuous inspection and adds up to the transportation cost (Kumar et al. 2020).

As of 2015, the total length of such pipelines stood at $8000 \mathrm{~km}$ globally. Holloway et al. (2008) suggested developing a central system of interconnected pipes to collect $\mathrm{CO}_{2}$ emitted from different artificial sources/industrial plants that can perform sequestration at some specific location. However, such a step has not so far been taken in India, possibly due to the economic feasibility issues.

\subsection{Sequestration}

\subsubsection{General point}


The final sequestration of carbon is the last stage in the three-tier process. It allows the final storage of the captured and transported carbon into carbon sinks. There are various types of carbon sequestration options depending on the technological advancement of the economy involved, the nature of the carbon to be sequestered and the nature of the sink itself.

Based on the above parameters, carbon sequestration has been broadly categorised (Lal, 2008; Kambale and Tripathi, 2010) as: (i) biotic sequestration, and (ii) abiotic sequestration.

\subsubsection{Biotic sequestration}

This refers to the biotic media through which carbon is sequestered. It requires a close symbiosis between plants and animals. The process is highly efficient due to the involvement of living beings in the storage process due to the input of less energy from outside the natural cycle. The primary process that aids in the biotic sequestration of carbon is photosynthesis. Carbon capture through photosynthesis is called phytoremediation and plants can act as potential $\mathrm{CO}_{2}$ sequestration options. Different species have different potentials and certain plants work better in certain environments such as urban or industrial areas (Govindaraju et al. 2021).

\section{a. Oceanic sequestration}

Oceans are vast harbours of plant life. The oceanic photosynthesis of these zones, especially the phytoplankton photosynthetic process itself sequesters $\sim 45 \mathrm{Pg} \mathrm{C} \mathrm{yr}^{-1}$ (Lal 2008). These 
phytoplanktons then deposit on the ocean floor, thus sequestering carbon. Oceans have consumed $25 \%$ of anthropogenic $\mathrm{CO}_{2}$ and act as a buffer towards extreme climatic catastrophes (Fig. S5: oceanic carbon flux). However, this has acidified the ocean water (Turley et al. 2010). Another method of stimulating phytoplankton growth has been hypothesized (Kambale and Tripathi 2010). The ocean if fertilized with iron can stimulate the growth of phytoplankton (Street and Payton 2005), which in turn would increase the rate of photosynthesis and increase the overall biomass. The former would consume more $\mathrm{CO}_{2}$, while the latter would sequester it when the phytoplanktons die.

\section{b. Terrestrial sequestration}

It is the most common type of carbon sequestration globally though with different intensity depending on the latitudinal extent being considered. Its intensity is highest near the tropical zone $\left(0^{\circ}-10^{\circ} \mathrm{N} / \mathrm{S}\right)$ and decreases towards the poles. The sequestration is directly proportional to the availability of biomass, which is itself guided by the latitudinal position. The sequestration occurs through the process of photosynthesis, where plants capture atmospheric $\mathrm{CO}_{2}$ to produce their food by utilising sunlight and water, and release oxygen (Lal 2008).

Terrestrial carbon sequestration has been occurring since plants appeared on the Earth much before animals in the Late Precambrian (Knauth and Kennedy 2009). This natural sequestration, a part of the global carbon cycle, has played a vital role in maintaining the homeostasis of the planet. However, since the $\mathrm{CO}_{2}$ levels exceeded the natural limit of $300 \mathrm{ppm}$, the natural 
sequestration process is not proving to be enough leading to a continuous rise in average global temperature (Section1.1).

There are three interdependent components of terrestrial sequestration viz., forests, wetlands and soils (Lal 2008, 2010).

- Forests (both afforested and reforested) store a major portion of the global carbon (Tong et al. 2020) and store it as lignin, an important constituent of the cellulose of the cell wall of a plant cell. This cellulose accounts for $50 \%$ of all cellular carbon in the biosphere (Zeikus 1981). The average rate of carbon sequestration through the forest is $\sim 1.58$ BT C $\mathrm{yr}^{-1}$ (Lorenz and Lal 2010), with a potential of storing up to 87 BT by 2050 (Sohngen and Mendelsohn 2003). Urban forests can play a dual role by providing green areas in dense settlements and perform sequestration in their biomass (e.g., roots, branches, leaves).

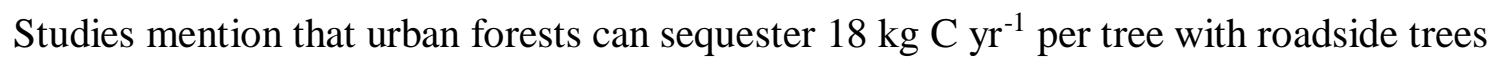
sequestering more $\mathrm{C}$ than those found in isolated areas (Govindaraju et al. 2021).

- The soil ecosystem includes all the types of soil on the Earth. Soil contains twice the carbon contained in the atmosphere and three times that of trees. It is a major carbon reservoir (Yadava and Thokchom 2021). Soil carbon sequestration differs from geological sequestration although both methods follow similar processes. While geological sequestration is abiotic and requires carbon storage beyond $1000 \mathrm{~m}$ depth, soil carbon sequestration is biotic and requires storage up to $1 \mathrm{~m}$ depth (Lal 2008).

- Wetland ecosystems include bogs, peats, marshes and other forms of histosols. They sequester C as Soil Organic Matter (SOM). They hold 20-30\% of the world soil carbon while occupying a mere 5-8\% of land area (Nahlik and Fennessy2016). Since the last ice 
age, around 13,500 years ago, wetlands have sequestered carbon at a steady rate of 0.1 BT C yr-1 (Lal 2008).

Mauthausen and Dooly (2019) ran a Monte Carlo simulation across tropical, subtropical, temperate and boreal forests on their sequestration potentials if those were reforested as per various sequestration scenarios. The data on sequestration parameters were taken from various literatures to model the sequestration of the above forest types. The median value obtained was 151.9 GT of C till 2150 (Fig. 4). This shows that 151.9 GT of C will be sequestered till 2150.

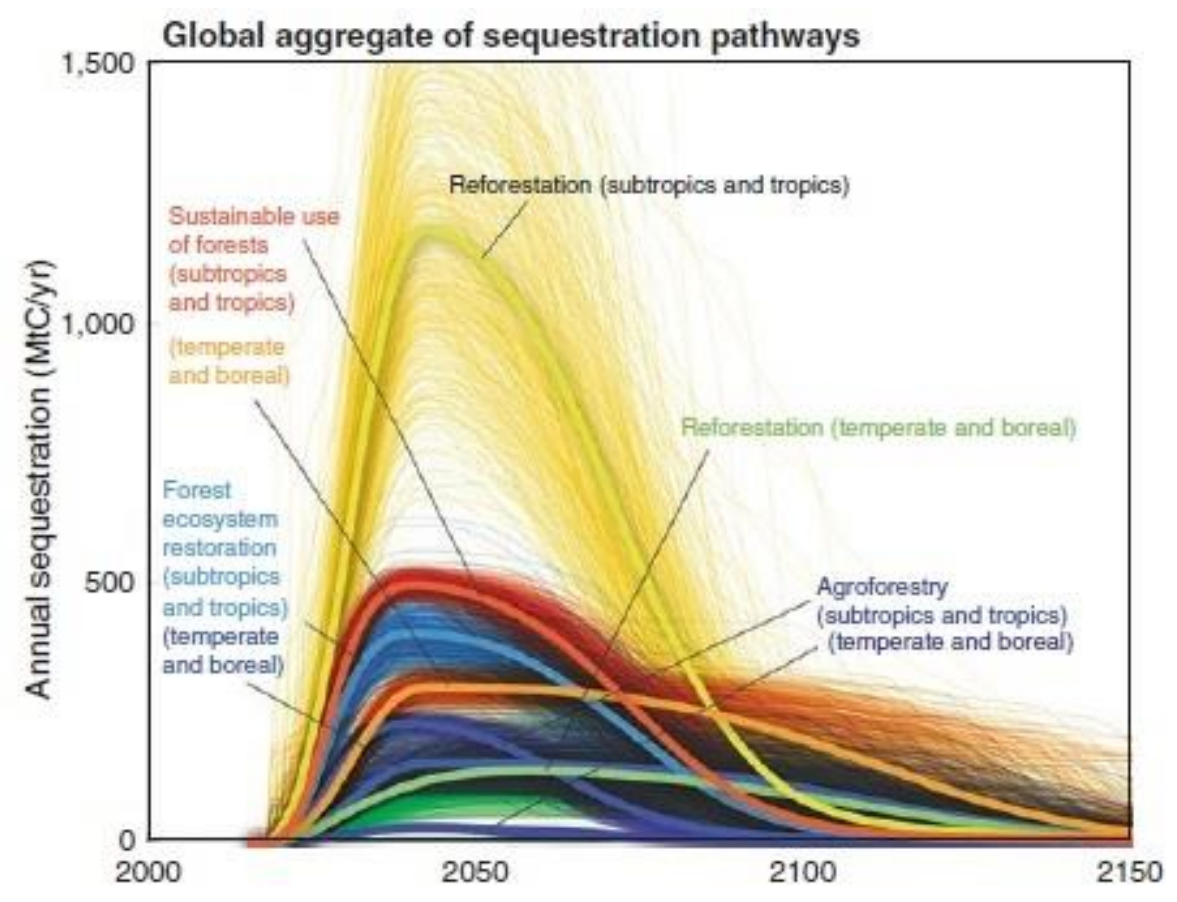

Fig 4. Terrestrial sequestration pathways showing mean annual sequestration rates from $2000-$ 2150 (reproduced from Meinshausen and Dooly 2019). 


\subsubsection{Abiotic sequestration}

Abiotic or engineered sequestration occurs without the action of the biotic components. Its rate, intensity and frequency can be altered. It is a more viable option than biotic sequestration as the technologies can be developed and refined to increase its efficiency. Global studies estimated a total geological sequestration capacity between $10,000-30,000 \mathrm{BT}$ of $\mathrm{CO}_{2}$. Such estimates are highly prospective and thus highly uncertain (Budinis et al. 2018). Wei et al. (2021) estimated the capacity to be 2082 BT, using a method developed by United States Department of Energy.

Brown et al. (2013) estimated the sequestration potential of the location Florida Panhandle through numerical modelling and arrived at a value of 4.55 BT. van der Meer and Yavuz (2009) calculated the sequestration capacity of Rotliegend Formation (The Netherlands). An empirical equation based on storage efficiency, aquifer volume, porosity and $\mathrm{CO}_{2}$ density at depths was used to arrive at a total value of 104.12 MT of sequestration potential. Thibeau et al. (2014) through 3D flow modelling ascertained the sequestration capacity of four sandstone formations from four different countries. These are Mt. Simon (USA), Basal (USA \& Canada), Bunter (UK) and Rotliegend (The Netherlands). The calculated sequestration values were 13.3, 16.2, 2.23 and 0.33 BT, respectively. Mt. Simon, Basal and Rotliegend are the onshore areas. The values for Rotliegend Formation differ significantly between those estimated by Van der Meer and Yavuz (2009) and by Thibeau et al. (2014). In any case, these are empirical estimates. VangkildePedersen et al. (2009) calculated a tentative geological sequestration capacity of Europe under the "GeoCapacity" Project. Empirical method was used considering various parameters such as:

- $\quad$ aquifer area, volume, thickness, $\mathrm{CO}_{2}$ density at depths, storage efficiency for aquifers 
- Storage capacity, recovery factor, $\mathrm{CO}_{2}$ at reservoir conditions, gas and oil formation volume factor, original gas and oil in place, the volume of injected and produced water for hydrocarbon reservoirs

- Storage capacity, producible gas, $\mathrm{CO}_{2}$ density and $\mathrm{CO}_{2}$ to $\mathrm{CH}_{4}$ exchange ratio for coal fields

The total capacity of potential European sites stood at 325 BTin aquifers, 30 BTin hydrocarbon fields and 1.5 BT in coal fields. (Faiz et al. 2007) calculated the sequestration capacity of coal seams in the Southern Sydney Basin, Australia. Calculations were made using field-collected data and previously published work. The calculations yielded values of 350 MT (with 100\% CBMR) and $175 \mathrm{MT}$ (with 50\% CBMR).

Besides the EU GeoCapacity project, other regional initiatives to estimate geologic storage potentials are North American Carbon Storage Atlas and $\mathrm{CO}_{2}$ atlas for the Norwegian Continental Shelf (Ringrose 2020).

There are three main types of abiotic sequestration (Lal 2008; Kambale and Tripathi 2010): (a) oceanic injection, $(b)$ geological sequestration and (c) mineral carbonation. 


\section{a. Oceanic injection}

Oceanic injection envisages injecting liquified $\mathrm{CO}_{2}$ in the ocean water at $\geqslant 1000 \mathrm{~m}$ depth for carbon storage. The total capacity of oceanic sequestration far exceeds the amount of carbon (5000 - 10000 GT) that the world fossil fuels can produce (Herzog et al. 2001).

Overturning of the ocean is also a major phenomenon and driver of oceanic life. Therefore, inevitably the injected $\mathrm{CO}_{2}$ would leak into the atmosphere, however, overturning time ranges from 300-1000 years and various data suggest that $\sim 20 \%$ of the injected $\mathrm{CO}_{2}$ would eventually leak. The leakage periods would vary inversely with the depths. Hence, $1000 \mathrm{~m}$ is the minimum depth for carbon storage (Herzog et al. 2001).At $1000 \mathrm{~m}$ depth, $\mathrm{CO}_{2}$ would remain as a droplet plume (Herzog et al. 2002), whereas at 3000 m liquefied $\mathrm{CO}_{2}$ can exist in the form of a lake in a depression (Benson et al.2008; Fig. S6). This method can actively sequester $2 \mathrm{BT}$ of $\mathrm{CO}_{2}$ annually. Those are valued across the entire geological media i.e., the total capacity (Bose and Satyanarayana 2021).

\section{b. Geological sequestration}

\section{b.1. General points}

Geologic carbon sequestration occurs in depleted hydrocarbon reservoirs and deep saline aquifers. $\mathrm{CO}_{2}$ is also used in the EOR, Enhances Gas Recovery (EGR) and Enhanced Coal Bed Methane Recovery (ECBMR) techniques as a method of passive sequestration in depleted/depleting hydrocarbon reservoirs. The primary purpose is to accentuate the recovery of 
oil, gas or methane from sources that have reached their output limit of oil, gas or methane (Riley 2010). Smit et al. (2014) pointed out that in any geological modelling of CCS, one must consider the effect of $(i)$ weathered rocks since that has a much lower permeability, and (ii) organic and biological matters in the sequestrated $\mathrm{CO}_{2}$.

\section{b.2. Depleted hydrocarbon reserves}

Depleted oil and gas reservoirs are currently the most viable option for sequestration.

Economically, these reservoirs have already been thoroughly researched, developed, scientifically explored and have the necessary infrastructure required to extract the hydrocarbon. The same approach can be used, with minor modification if required, to inject $\mathrm{CO}_{2}$ into them. $\mathrm{CO}_{2}$ injection in a tight hydrocarbon reservoir has two purposes $(i)$ sequestration of $\mathrm{CO}_{2}$, and (ii) enhanced oil recovery from the reservoir (Jia et al. 2020). However, such an injection can lead to induced seismicity (Vasco et al. 2020). In particular, a basin with fractures and faults can induce seismicity if $\mathrm{CO}_{2}$ is injected, or it can elevate pore pressure in the basin (review in Zakharova et al. 2020; also see Dasgupta and Mukherjee 2020). To avoid these, reservoirs are to be monitored geodetically (Vasco et al. 2020). Monitoring is also required due to pressure difference during and after injection. Such issues manifest as land surface deformations. The all-weather monitoring capabilities of Inferometric Synthetic Aperture Radar (InSAR) can find applications in long term $\mathrm{CO}_{2}$ migration monitoring (by monitoring land surface deformation) (Zhang et al. 2022). Other remote sensing techniques such as Active microwave remote sensing and LiDAR also hold significant potential in terms of monitoring capabilities (Zhang et al. 2021). Review by Nobel et al (2012) concludes that biological monitoring using DNA fingerprinting and bacterial counts can also be used for efficient monitoring. Given that the technology is advancing quickly, 
biological monitoring demands exploration. Leakages also can manifest due to geochemical interaction and temperature/pressure differentials between the $\mathrm{CO}_{2}$ and the host rock in which it is injected (Gholami et al. 2021). Biological monitoring has more potential in detecting leaks and other environmental changes that happen due to those leakages (Nobel et al. 2012).The Barmer basin (Rajasthan, western India) is a tight reservoir, but carbon sequestration has not been started there.

Geologically too, tight reservoirs are well developed to hold off the $\mathrm{CO}_{2}$ because of the already present geological structures that contained the oil and gas for millions of years. The prerequisite is to store the $\mathrm{CO}_{2}$ at $>800 \mathrm{~m}$ depth (Riley 2010, Ringrose 2020) to ensure the necessary density to keep the $\mathrm{CO}_{2}$ in a super-critical or liquid phase (Fig. $\mathrm{S} 7$ for $\mathrm{CO}_{2}$-depth density relation). However, the density also depends on local temperature and geothermal gradients (Ringrose 2020). The EOR, EGR and ECBMR are applied to both sequester carbon and enhance the production of oil, gas and methanefrom their respective reservoirs.

\section{b.3. Enhanced Oil Recovery (EOR)}

In EOR, $\mathrm{CO}_{2}$ is injected into an oil well to reduce its viscosity, enabling an increase oil production (Section 2.1). This process has been in practice since its first execution in Oklahoma (Karmakar 2016). Since then, 136 active EOR projects have been in practice worldwide (Ettehadtavakkol 2016). This method is deployed after the primary and secondary phases, which involve using $\mathrm{CO}_{2}$ and water to extract the oil, respectively. The remaining oil is then extracted by guiding alternating streams of water and supercritical $\mathrm{CO}_{2}$, in the tertiary phase, through the 
parts of the field where recoverable oil remains. This phase can enhance the life cycle of the oil field for decades (Riley 2010; Mariyamma et al. 2015).

\section{b.4. Enhanced Gas Recovery (EGR)}

$\mathrm{CO}_{2}$ can be used to increase the productivity of depleting gas fields by using $\mathrm{CO}_{2}$ to displace the natural gas since $\mathrm{CO}_{2}$ is denser. Both EGR and EOR are considered suitable and relatively safe techniques of sequestration as both possess natural sealing mechanisms that held the oil and gas for millions of years before they were extracted (Riley 2010; Mariyamma et al. 2015).

\section{b.5. Enhanced coal bed methane recovery (ECBMR)}

Carbon sequestration in coal seams can enhance the coal bed methane recovery. Methane constitutes $\sim 95 \%$ of the total number of gases present in the coal seams. This simple process involves replacement of pre-existing $\mathrm{CH}_{4}$ by injecting $\mathrm{CO}_{2}$. The cost of either one of the processes can be used for dual purposes, with an affinity of coal for $\mathrm{CO}_{2}$ providing an additional advantage (Vishal et al. 2012; Singh and Mohanty 2014; Sen2017). Methane produced is used as an energy source rather than releasing it into the atmosphere, which can defeat the purpose of sequestering $\mathrm{CO}_{2}$ as methane is 23 times more potent $\mathrm{GHG}$ than $\mathrm{CO}_{2}$ (Riley 2010). A study by Tambaria et al. (2022) concluded that moisture, maceral and pore size and characteristics of injected gas are the three most important factor that determine the efficiency of the ECBMR process. Table 6 of Leung et al. (2014) lists the ECBMR plants. 
These three options, but more specifically the EOR, is favoured in industries because the cost of capture is balanced or even exceeded by the cost of additional oil that is recovered. However, Sekera and Lichtenberger (2020) have concluded in their review that carbon capture is a feasible technology only when the captured carbon is stored and not commercially utilised in any manner. Usage of captured carbon for oil recovery simply shifts the emission source.

\section{b.6. Deep saline aquifers}

Saline aquifers contain brackish water and hence are of no major use due to the presence of excess salt. Dayal et al. (2008) proposed measuring the baseline concentration for atmospheric $\mathrm{CO}_{2}$ and soil carbon content (organic and inorganic) in shallow saline aquifers with sequestration potential. Borehole data, if any, can help to monitor and model seepage. Reservoir simulation models point out that a mere $0.01-0.1 \%$ of the volume of saline aquifers can be used for storage considering 50 years of injection (Budinis et al. 2018). Notwithstanding, the volumetric carbon sequestration capacity of deep saline aquifers (100 - 10,000 BT; Bradshaw et al. 2007) remains greater than any other geological sequestration sites (Herzog 2009; GCCSI 2020). If the models consider aquifers with traps, the number comes down to 320 BT (Koide et al. 1992) and 200 BT (Hendricks and Blok 1995). Van der Meer and Yavuz (2009) considered Bradshaw et al. (2007)'s estimate to be highly unreliable. Recently, Wei et al. (2021) have estimated the mean capacity to be 1914 BT and the range between $888-5126$ BT. Active aquifer sequestration sites e.g., in Sleipner (Norway) has been storing $1 \mathrm{MT} \mathrm{CO}_{2}$ annually in the Utsira Formation of the North Sea since 1996 (GCCSI 2020). The Shenhua CCS project also sequesters $0.1 \mathrm{MT} \mathrm{CO}_{2}$ in the saline formations of the Ordos Basin, China (Diao et al. 2014; global sequestration map of deep saline aquifers in Fig. S8). 
Ribeiro e Sousa (2012) referred that the injected $\mathrm{CO}_{2}$ in rocks can do one of these: (i) displace existing fluid, (ii) dissolve in the existing fluid, (iii) reach with minerals, (iv) do a combination of the stated three possibilities. The $\mathrm{CO}_{2}$ can be sequestered in the following four ways (Radha and Navrotsky 2013; Mariyamma et al. 2015; Potdar and Vishal 2016; Tsang and Niemi 2017):

i) Structural trapping- $\mathrm{CO}_{2}$ can be trapped as plumes at the aquifer top, with its upward movement stopped by structural caprocks. Such plumes lead to mineral precipitation with a direct correlation between the plume size and the rate of precipitation (Maalim et al. 2021; Fig. S8).

ii) Capillary trapping- $\mathrm{CO}_{2}$ injecting into the pore of the aquifer rock and trapped as bubbles is also a possible sequestration mechanism (Fig. S10).

iii) Dissolution - $\mathrm{CO}_{2}$ can be dissolved in aquifer water. This $\mathrm{CO}_{2}$ saturated water becomes denser and migrates to the bottom of the aquifer as finger-like projections.

iv) Mineralization- $\mathrm{CO}_{2}$ can also transform and deposit as mineral carbonates after reaction between the aquifer minerals, $\mathrm{CO}_{2}$ and water.

Deep saline aquifers represent a key sequestration option for $\mathrm{CO}_{2}$, however, the four processes described above require significant amount of time, upto 100s of years. A review by Rathnaweera and Ranjith (2020) shows that adding nanoparticles in the injected $\mathrm{CO}_{2}$ can significantly reduce the mixing time as well as prevent back migration of $\mathrm{CO}_{2}$, thus preventing leakages. 


\section{c. Mineral carbonation}

The natural process of carbonation (eqn. 1) is replicated at an industry-scale to sequester carbon into stable mineral carbonates e.g., calcite $\left(\mathrm{CaCO}_{3}\right)$, magnesite $\left(\mathrm{MgCO}_{3}\right)$ and siderite $(\mathrm{FeCO} 3)$ in the form of rocks (Jain et al. 2016).

Metal oxide $+\mathrm{CO} 2 \rightarrow$ Metal carbonates + Heat

Mineral carbonation is presumably a safer alternative to the other geological sequestration techniques since carbon is immobilized into stable carbonate as rocks (Sana et al. 2014; del Real and Vishal, 2016). This process can safely sequester $\sim 36,000 \mathrm{BT}$ of $\mathrm{CO}_{2}$, which far exceeds the sequestration potential of geological reservoirs. The only downside is that this process is extremely time-taking, and emission rates far exceed it. Research is underway to understand the optimum way to increase the rate of natural carbonation (Yuen et al. 2016).

This process can be either ex-situ or in-situ.In in-situ carbonation, the capture and storage of carbon occur underground and is also one of the associated processes in sequestration in deep saline aquifers (Section 2.4.3b.6). In ex-situ, the capture occurs on the surface and the storage takes place in suitable repositories, specifically in the large continental flood basalts across the world such as the Columbia River flood basalts and the Deccan trap basalts (McGrail et al. 2006; Jain et al. 2016; Mukherjee et al. 2017, 2020). Basalts terrains with (i) impermeable layers within the interflow zones, and (ii) sills and dykes are suitable for $\mathrm{CO}_{2}$ sequestration. Here the impermeable layers, sills and dykes act as seals or caprocks (Zakharova et al. 2020). In the Deccan trap (India) the dominant rock type is basalt (Misra et al. 2014) and it consists of bole beds as the inter-flow layers (Ghosh et al. 2006), and dykes (Misra and Mukherjee2015) in many places. Those specific locations in the Deccan trap are to be investigated for sequestration 
operation, keeping also in mind that basaltic terrain alone is not the only criterion to succeed in sequestration.

Kraczyket al. (2015) emphasized the need to estimate in-situ stress magnitudes and vulnerability to deformation at the planned CCS location in rocks. The degree to which $\mathrm{CO}_{2}$ moves laterally and vertically, when basalt flow that lies above the target sequestration locations, is critical in the context of CCS in basaltic traps (McGrail et al. 2008).

Nevertheless, abiotic sequestration options such as depleted oil and gas fields and saline aquifers have been the primary sequestration options for the last $\sim 70$ years. These methods have some inherent drawbacks such as less efficiency, high energy penalty to capture carbon from large point sources, infrastructural costs, and feasibility issue for permanent storages (due to leakage risks) in the geological reservoirs (Celia and Bachu 2003; Xie and Economides 2009; Silva et al. 2015; Liu et al. 2019; Onishi et al. 2019).

\subsubsection{Sequestration through microalgae}

Microalgae sequestration has been extensively studied in recent years. Biotic sequestration options have been adopted but not widely due to land constraints and ecologicalfactors. This is because biotic sequestration depends on either afforestation or reforestation (Smith and Torn 2013). Microalgae sequestration is considered a sustainable alternative to the above methods. This technique can be readily applied to point sources and can be utilized in the transportation 
sector not only for capturing carbon but also for the production or biofuels (using the microalgae) leading to a circular system (Onyeaka et al. 2021). Microalgae can be symbiotically used with bacteria in wastewater treatment plants. The $\mathrm{CO}_{2}$ generated by the bacteria, during the process of decomposing waste, is used by the microalgae to sequester it and inturn the oxygen produced by the microalgae helps to sustain the bacteria. This way the waste gets decomposed and algal biomass is also produced. This system needs further research and investigation to overcome its challenges such as inefficient $\mathrm{CO}_{2}$ mixing in the water and inefficient algal growth in industrial effluents. Employing this natural symbiosis can lead to cost effective and highly efficient wastewater treatment cum sequestration plants (Vishwanaathan et al. 2022).

Till now, > 25000 species have been identified that can naturally fix $\mathrm{CO}_{2}$ by photosynthesis. Each species has unique adaptations such as halotolerance (hlorella $), \mathrm{SO}_{x}$ tolerance (Scenedesmus obliquus) and thermotolerance (Picochlorum). Under favorable conditions, they tend to generate exponentially with capture efficiency 10-50 times more than that of terrestrial plants. One $\mathrm{kg}$ of microalgal biomass can fix $1.38 \mathrm{~kg}$ of $\mathrm{CO}_{2}$. Subsequently, microalgae can be grown using $\mathrm{CO}_{2}$ from industrial sources or flue gases expelled by the large point sources. A review by Thomas et al. (2016) concludes that the strategy of using flue gases directly for microalgal growth can be a fruitful method. Certain compounds need to be eliminated from flue gases such SOx and NOx, for optimum growth of microalgae. The cost of artificial microalgae culture posed some drawbacks, but this cost can be offset by using microalgae for biofuels, biofertilizers, wastewater treatment etc. (Osman et al. 2020). Table S4 presents by-products of different microalgae. However, uniform $\mathrm{CO}_{2}$ diffusion in the artificial culture medium is a current challenge in this field (Vale et al. 2020). 


\section{India's carbon footprint}

India consists of 28 states and 8 union territories. The country's population is $>1.3$ billion (UN 2019). Meeting the energy demands of such a huge population is a challenge, especially when it is a key contributor to economic growth (Paul and Bhattacharya, 2004). Shahbaz et al. (2017) conclude that relation between economic growth and energy consumption can follow growth (energy $\rightarrow$ economic growth), conservative (economic growth $\rightarrow$ energy), feedback (energy $\leftrightarrow$ economic growth) or neutrality (energy $\neq$ economic growth) hypotheses depending on the country. After reviewing 17 Indian studies, Shahbaz et al. (2017) found that 14 of them indicate some relation (growth, conservation and feedback) between economic growth and energy consumption, and the remainder indicate a neutral relation. India's economic growth and energy consumption can therefore be correlated.

Between 1980 to 1991, the Indian GDP had an average growth rate of 3\%. However, the Indian economy experienced a revolutionary turn in 1991 when the finance minister of the country introduced liberalisation, privatization, and globalisation (LPG) policy. The policy allowed the country to recover from a severe economic crisis and accelerated the economic growth (Ravan 2014). The aim was to boost economic growth along with reducing poverty and unemployment. The aim was certainly achieved. From 1991-to 2019 the average annual GDP growth rate stood at 6.375\% (Tiwari 2011; World Bank 2020).

However, this growth came at a cost. In the industrial sector, the country flourished manifold, and subsequently, their energy consumption increased. This energy, $>80 \%$ of which was derived 
from the combustion of fossil fuels, almost quadrupled the $\mathrm{CO}_{2}$ emissions of India. While the 1994 emissions stood at 779 million tonnes, the emission values in 2019 stood at 3.6 BT (Garg et al. 2017; UNEP 2020) (Fig. 5).This relationship, however, has been non-linear. An empirical analysis by Javid and Khan (2020), concludes that the average growth rates of emissions (5.5\%) and GDP (6.3\%) were almost identical between 1990 - 2009, while between 2010 -2016 the average growth rate of emission $(5.13 \%)$ has been less than the average GDP growth rate (7.34\%) As of 2019, India's $\mathrm{CO}_{2}$ emission per capita stood at 2.68 metric tonnes, which shows a constant increase (Table 2).

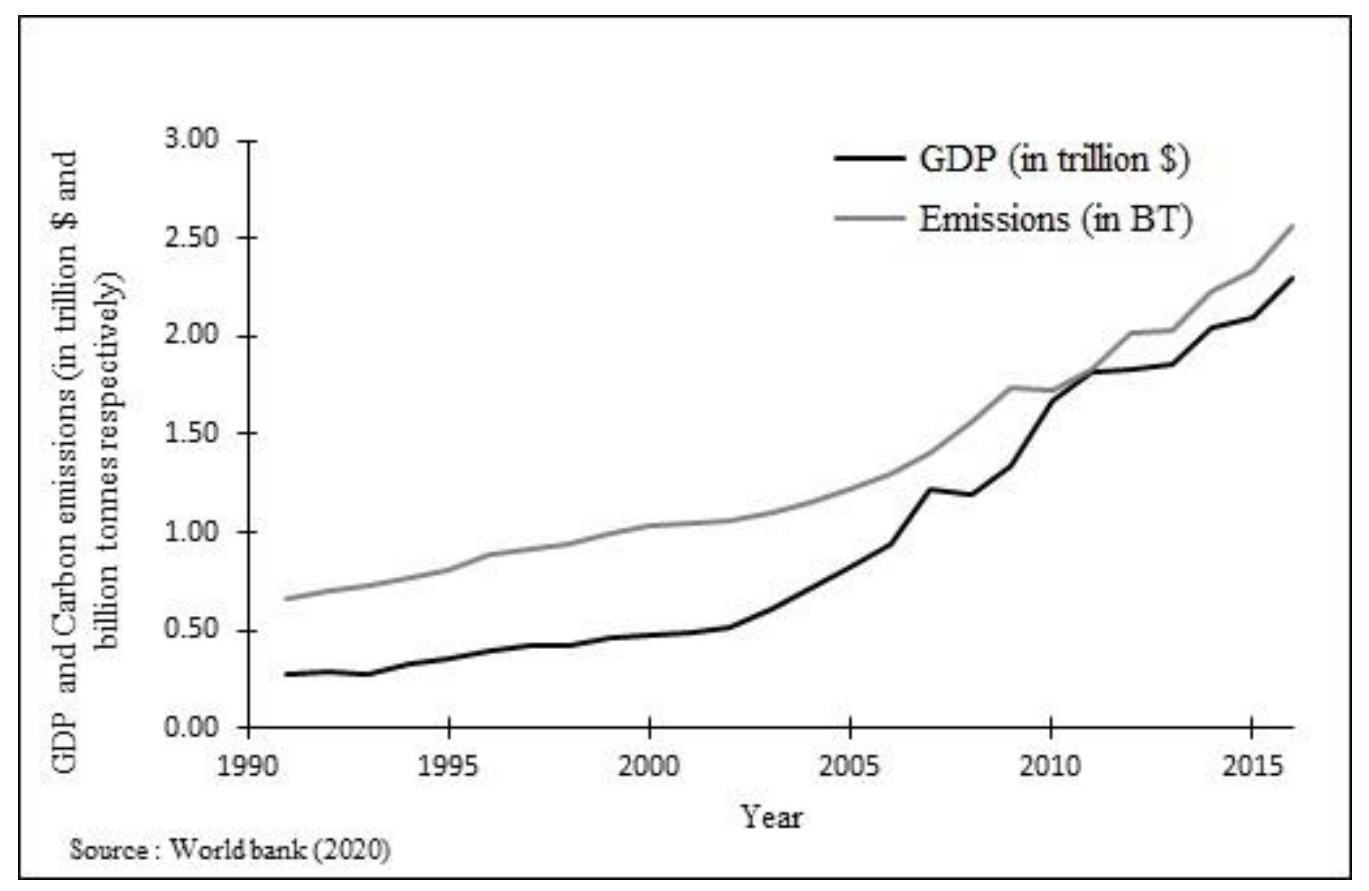

Fig 5. Year wise values of GDP and carbon emissions for India (1990-2016) (Calculation made from World Bank data).

These energy demands are met through fossil fuel combustion (Section 1) at the cost of voluminous $\mathrm{CO}_{2}$ released. Added to this is the industrial emission (Table 4). The power sector (dominated by coal) contributes $\sim 50 \%$ of the total $\mathrm{CO}_{2}$ emissions, followed by manufacturing 
and construction $(\sim 22 \%)$, and transport $(\sim 11 \%)$, industries $(\sim 5 \%)$ (Internet reference; Table 4$)$. In the transport sector, road transport accounts for $94.5 \%$ of the total $\mathrm{CO}_{2}$ emissions (Senthilkumar 2021). Out of 20-30\% from industrial sources; the cement industry, oil refineries and iron and steel account for 7, 6 and 5\% emissions, respectively (Goel et al. 2021b).

Table 2. Year-wise per capita emission of India from 2016-2019 (Estimations made from UNEP 2017; UNEP 2018; UNEP 2019; UNEP 2020).

\begin{tabular}{lcccc}
\hline Year & $\mathbf{2 0 1 9}$ & $\mathbf{2 0 1 8}$ & $\mathbf{2 0 1 7}$ & $\mathbf{2 0 1 6}$ \\
\hline Emissions (in & 2.68 & 2.67 & 2.57 & 2.52 \\
metric tonnes) & & & & \\
\hline
\end{tabular}

Table 3. $\mathrm{CO}_{2}$ emission values of four major Indian sectors from 2011 to 2016 (internet reference). 


\begin{tabular}{|l|l|l|l|l|l|}
\hline Year & $\begin{array}{l}\text { Power } \\
\text { generation } \mathbf{( \% )}\end{array}$ & $\begin{array}{l}\text { Industry } \\
(\boldsymbol{\%})\end{array}$ & $\begin{array}{l}\text { Manufacturing \& } \\
\text { Construction }(\boldsymbol{\%})\end{array}$ & $\begin{array}{l}\text { Transport } \\
(\boldsymbol{\%})\end{array}$ & $\begin{array}{l}\text { Others } \\
(\boldsymbol{\%})\end{array}$ \\
\hline 2011 & 46.90 & 5.22 & 24.34 & 11.22 & 12.32 \\
\hline 2012 & 50.11 & 5.11 & 21.80 & 11.04 & 11.94 \\
\hline 2013 & 49.64 & 5.15 & 23.41 & 11.05 & 10.75 \\
\hline 2014 & 50.36 & 4.87 & 22.85 & 10.50 & 11.41 \\
\hline 2015 & 48.18 & 4.89 & 22.19 & 11.13 & 13.61 \\
\hline 2016 & 46.87 & 4.67 & 22.51 & 11.19 & 14.77 \\
\hline
\end{tabular}

\subsection{Major emission zones}

Although the above data covers the entire country, there are certain zones or "hotspots" with the highest rates ofemission owing mainly due to the presence of large emission sources. Industries and thermal power plants are the two chief agents. Table 4 presents the hotspot states, districts and sources.

Table 4. CCS hotspot states, districts, and sources as of 2013 government reports (compiled from Garg et al. 2017).

\begin{tabular}{|l|l|l|}
\hline Hotspot states & Hotspot districts & Hotspot sources \\
\hline Uttar Pradesh & Kachchh (Gujarat) & $\begin{array}{l}\text { Vidhyanachal thermal power } \\
\text { station (Madhya Pradesh) }\end{array}$ \\
\hline Maharashtra & Sonbhadra (Uttar Pradesh) & $\begin{array}{l}\text { Mundra thermal power station } \\
\text { (Gujarat) }\end{array}$ \\
\hline Andhra Pradesh & Korba (Chhattisgarh) & Talcher thermal power station \\
\hline
\end{tabular}




\begin{tabular}{|l|l|l|}
\hline & & (Orissa) \\
\hline
\end{tabular}

25 out of 641 districts of India (Table 5) are amongst the top emitters of $\mathrm{CO}_{2}$, which are distributed among 14 states of the country. There is a skewed distribution of these districts among the states.

Table 5. States with the highest numbers of hotspot districts (compiled from Garg et al. 2017).

\begin{tabular}{|l|l|}
\hline States & Number of districts \\
\hline Andhra Pradesh & 5 \\
\hline Chhattisgarh & 3 \\
\hline Jharkhand, Uttar Pradesh, Gujarat, West Bengal, Maharashtra & 2 \\
\hline $\begin{array}{l}\text { Haryana, Madhya Pradesh, Bihar, Odisha, Rajasthan, } \\
\text { Karnataka, and Tamil Nadu }\end{array}$ & 1 \\
\hline
\end{tabular}

These 25 districts accounted for $\sim 44 \%$ of the total $\mathrm{CO}_{2}$ emission of the country, in 2013 and the rest 56\% were distributed among the remaining 616 districts (Garg et al. 2017). The share of these 25 districts increased from $35 \%$ in 2005 to reach $44 \%$ in 2013 . This highlighted that the energy production and consumption increase in the states as well as the increase in inequality of energy consumption and expenditure. 
In 2013, $\mathrm{CO}_{2}$ emissions of these 25 districts were $>15 \mathrm{MT}$ and district-wise average $\mathrm{CO}_{2}$ emission stood at 3.07 MT. A total of 64 districts accounted for $60 \%$ of the total $\mathrm{CO}_{2}$ emissions and the remainder $40 \%$ was distributed among the remaining 577 districts. This shows a clear disparity in the volume of emissions. Since the emission patterns are directly proportional to the energy consumption patterns, it also indicates the difference in the energy consumption patterns of the districts.

After analysing several government reports and independent works, Mohan et al. (2019) presented the leading states in emissions from various sectors (Table 6). Uttar Pradesh and Maharashtra are amongst the top three emitter states. Even the agricultural sector emission is led by Uttar Pradesh with Punjab and Haryana follows next.

Table 6. Top three states in sectoral emissions (compiled from Mohan et al. 2019).

States with respective emissions

$\mathrm{CO}_{2} \mathrm{CO}_{2} \quad \mathrm{CO}_{2}$

\begin{tabular}{lllllll} 
Sectors & I & Emissions & II & Emissions & III & Emissions \\
& & $(\mathrm{MT})$ & & $(\mathrm{MT})$ & & $(\mathrm{MT})$ \\
\hline Electricity & Uttar & \multirow{2}{*}{123.8} & Maharashtra & 107.14 & Chhattisgarh & 92.94 \\
generation & Pradesh & & & &
\end{tabular}




\begin{tabular}{lllllll} 
Transport & Maharashtra & 34.39 & Tamil Nadu & 21.57 & Uttar & 20.2 \\
Commercial & Tamil Nadu & 1.36 & Maharashtra & 1.19 & Uttar & \\
& & & & & Pradesh & \\
Agricultural & Uttar & & & & & \\
& Pradesh & 4.93 & Punjab & 3.04 & Haryana & 2.88 \\
& & & & & \\
\hline
\end{tabular}

\subsection{India's $\mathrm{CO}_{2}$ emission projections}

One year after submitting its Intended Nationally Determined Contribution (INDC), India officially ratified the Paris Accord in 2016. India has committed to meet $40 \%$ of its electricity demands from non-fossil fuel-based energy by 2030 (Fig. 6). By 2030 it planned to reduce its emission intensity by $33-35 \%$ of the 2005 levels. The INDC also includes provisions for an additional carbon sink for 2.5 - 3 BT of carbon (IEA2021; Ray 2021). This does sound an ambitious goal given that India must tackle its core issue of grass-root development along with transitioning its energy sources. 


\section{Percent non-fossil fuel based generation capacity}

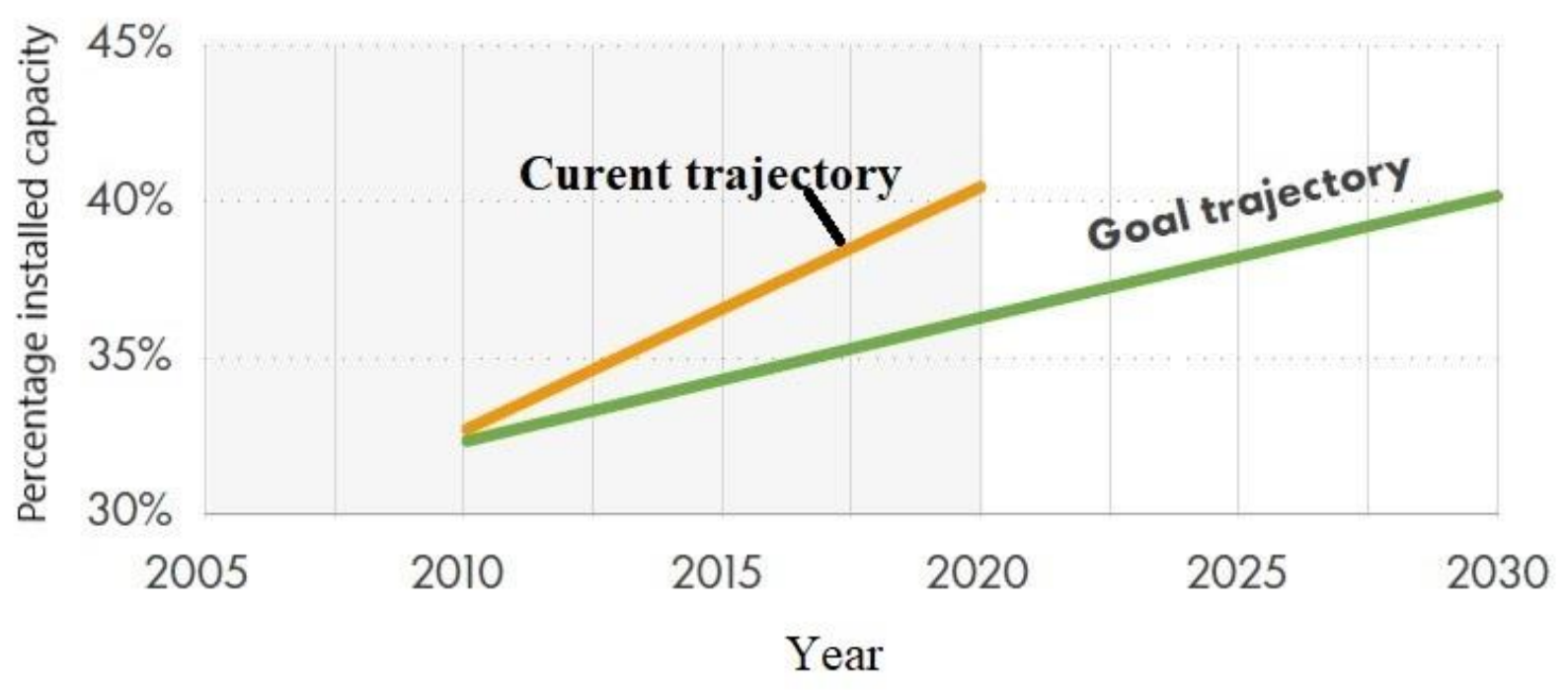

Fig 6. Current and projected trajectory for non-fossil fuel based electricity installed capacity of India (Modified from fig. 1 of SG and TERI 2021).

India's emission intensity in 2005 stood at $0.47 \mathrm{Mt} \mathrm{CO}_{2}$ per $\$ 1000$ of GDP. Considering the reduction goal of $33-35 \%$ of 2005 levels, the emission intensity in 2030 should ideally stand between 0.3149 to $0.3055 \mathrm{Mt} \mathrm{CO}$ per $\$ 1000$ of GDP. The emission intensity of India in 2019 stood at $1.27 \mathrm{Mt} \mathrm{CO}_{2}$ per $\$ 1000$ of GDP. Note a constant decrease from $1.45 \mathrm{Mt} \mathrm{CO}_{2}$ per $\$ 1000$ of GDP in 2016 followed by 1.29, 1.33 in 2017 and 2018 (estimations made from data in UNEP 2017, UNEP 2018, UNEP 2019 and UNEP 2020). Interestingly, China's emission intensity in 2019 stood at $0.97 \mathrm{Mt} \mathrm{CO}_{2}$ per $\$ 1000$ of GDP. In thermal power generation with 35\%

efficiency, India's emission intensity stands at $0.9 \mathrm{Kg} \mathrm{CO}_{2} / \mathrm{kWh}$ (Niharika et al. 2021). Adjusting the values for a $33-35 \%$ decrease, the intensity should be $0.603-0.585 \mathrm{Kg} \mathrm{CO}_{2} / \mathrm{kWh}$. Assuming an ideal scenario, if India achieves its target for the emission intensity by 2030, the country's $\mathrm{CO}_{2}$ emission would stand at 5.6 BT in 2030 (Frank 2015). du Can et al. (2019) however predicted the value to be 4.0 BT in 2030 and 7.4 BT in 2050. It also shows that India's 
emission intensity in 2030 would decrease by $34 \%$ from 2005 level, thus achieving it INDC target. This would happen even if India stuck to Business-As-Usual (BAU) scenario, without taking a load of new initiatives (Frank 2015, du Can et al. 2019). The $\mathrm{CO}_{2}$ emission projections, though differs in both the studies, it concludes that the absolute emission of India is not decreasing soon. If the emission intensity decreases to $0.31 \mathrm{Mt} \mathrm{CO}_{2}$ per $\$ 1000$ of GDP, it means that energy production is more efficient i.e., there is less emission per \$1000 of GDP.

India has not announced any peak year of emission. Prakash Javadekar, the Minister of Environment, Forest, and Climate Change stated in 2015: "The world is not expecting... India to announce its peaking year" and "Countries know where India stands and what its requirements [development needs] are and therefore nobody has asked us for [the] peaking year" (Khadka 2015).

du Pont et al. (2017) concluded that in order to stay in line with the Paris agreement goals, India would have to peak its emission by 2033. SG and TERI (2021) in their Net Zero Emissions (NZE) by 2050 scenario have chalked out a probable future pathway for India's sectoral emissions (Fig. 7). According to their NZE scenarios: 
Emissions by sector, $\mathrm{CO}_{2}$ equivalent, $\mathrm{Gt}_{\mathrm{CO}_{2}}$ e per year

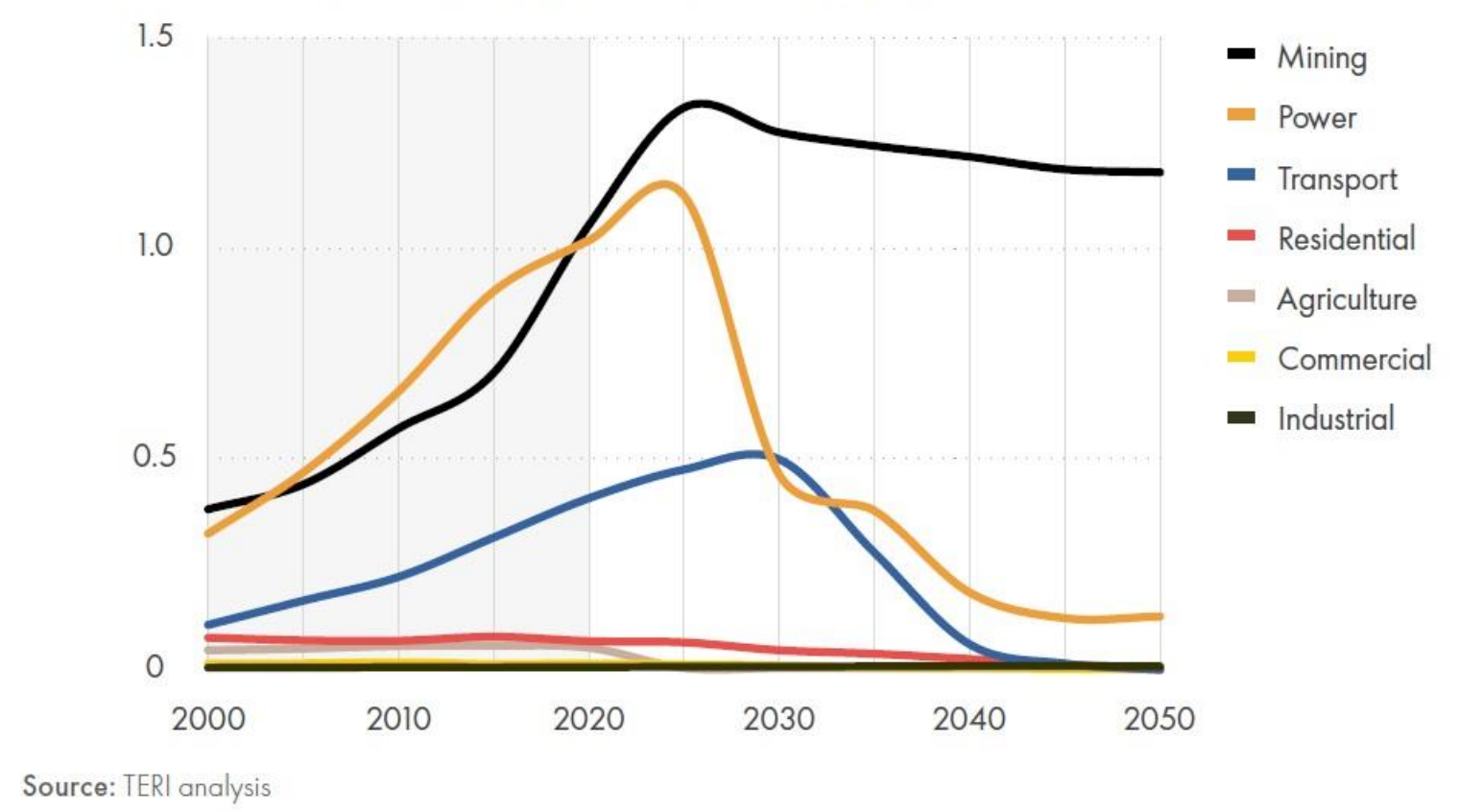

Fig 7. Sectoral emission projections for India under NZE scenario (Reproduced from fig. 13 of SG and TERI 2021).

- Electricity generation sector - By the second half of the $2020 \mathrm{~s}, \sim 75 \%$ of thermal power plants would be decommissioned and by 2050 solar and wind energy would constitute $90 \%$ of total electricity generation. The entire electrical system would grow four times, yet emissions would be half of the current values.

- $\quad$ Transport sector - The demand for electric vehicles would increase in the 2020 s.

Subsequently, there would be either electric vehicles or fuel cell vehicles. Fuel cell vehicles would be powered by green hydrogen obtained from the electrolysis of water.

- Residential, commercial and agriculture - The residential and commercial sectors' complete transition to renewable energy-based electricity by 2050 while the agricultural sector will continue to depend on solar energy and biodiesel. 
- Industry - Industrial emissions would reach a plateau after 2025. There would not be a significant decrease due to lack of readily available technology, however, there would be a continued transition. This sector would need CCS technologies to decrease their emission during the transition process (Section 1). The NZE scenario estimated $1.3 \mathrm{BT}$ of residual $\mathrm{CO}_{2}$ from the industrial sector. 0.9 $\mathrm{BT}$ of this residual $\mathrm{CO}_{2}$ can be sequestered biotically (forests, wetlands and mangroves) while the remaining $0.4 \mathrm{BT}$ would need some form of geologic sequestration. Thus, this NZE scenario considers CCUS as an essential part of the policy, if 2050 is taken as a Net-Zero year. This would require the Indian government to frame CCS focussed policies and aim technological deployment in near term, probably within this decade.

Zhang et al. (2021) assessed various CCS-based policy options in China such as carbon pricing (setting a price for amount of carbon produced usually based on per tonne emission) and government incentives. Studies in this line are needed in Indian context.

\subsection{Carbon emissions during COVID-19}

The Covid-19 pandemic hit the entire world in 2020, forcing a global shutdown of business, transport, industry, and overall normal functions. Because of this shutdown, the planet experienced a major global fall of atmospheric $\mathrm{CO}_{2}$ level, since the second world war (Liu et al. 2020). The $\mathrm{CO}_{2}$ in April 2020 were 17\% less than the mean levels of 2019 (Le Quéré et al. 2020). In India, the decline was that of $205 \mathrm{Mt}$, a $15.4 \%$ decline in the first half of 2020, as compared to the same period in 2019 (Liu et al. 2020). However, such decline came at the cost of 
economic slowdown. After the pandemic (hopefully) gets over, the $\mathrm{CO}_{2}$ concentration in the atmosphere is bound to increase.

\section{Carbon sequestration in India}

If the increase in $\mathrm{CO}_{2}$ emission remains unchecked then the per capita emission values would double in a decade, posing another challenge for the Indian Government apart from the already lingering issues of sustained socio-economic growth (Saleth et al. 2020; Bagchi 2020),population boom (Debdata et al. 2018), poverty (Kurinjimalar and Prassanna 2018) and inequality gap (Sankar 2020). The current challenge is to address these issues while continuously increasing the production and sustainable consumption of (cleaner) energy (Maji 2019). Even though the world is pushing towards cleaner forms of energy, low per capita income, and high coal reserves (326.05 billion tonnes as of 01-April-2019 (GOI 2020a) still render coal-generated power to be the cheapest in India (Bhattacharya 2018). Even though alternatives like solar and wind are gradually coming up, coal would continue to be the main source of power for India in 2030, at around 60\% (Shearer et al. 2017; Section 1). Thus, carbon capture and storage are necessary technology that should be developed in the country soon. India is yet to do substantial developments in the field of CCS and implement them (Section 4.1).

\subsection{Research \& Developments in India}

In 2003, India became the founder member of the Carbon Sequestration Leadership Forum (CSLF), launched by the US Department of Energy (Goel 2021b) and since the G8 meeting in Gleneagles (2005), international attention concerning CCS initiatives have garnered over India. 
Many European Governments, especially UK, expressed significant interest in collaborating with India to develop CCS technologies. In 2006-2007, international workshops on the research and development challenges in the field of CCS was organised by the DST at the National Geophysical Research Institute (NGRI; Shackley and Verma 2008). The years 2006 to 2008 saw significant development in the field such as the establishment of a National Program on Carbon Sequestration (NPCS) by DST in 2006/2007.

Goel (2008) presented the following three thrust areas for CCS in the Indian context: $(i)$ precombustion carbon capture research, (ii) modelling studies for geological sequestration, and (iii) monitoring of sequestration locations. Since then, active research is being carried out in the field of CCS to compete in the international arena. With NPCS, India became one of the few developing economies that began R\&D investments in CCS (TERI 2013; Mukherjee et al. 2014; Goel et al. 2021). This included a call for proposals for research in the field of CCS (Chakroborty 2008).

DST has identified four thrust areas for active research under the aegis of NPCS: (i) CCS process development, (ii) policy and development studies, (iii) network terrestrial agro-forestry sequestration modelling, and (iv) bio-sequestration through micro algae bio-fixation (TERI 2013; Mukherjee et al. 2014). Under the ambit of NPCS, India hosted an international workshop on R\&D challenges in CCS technology in 2007. Experts and young scientists attended it from 19 countries. DST also presided over the formation of the "Indian $\mathrm{CO}_{2}$ Sequestration and Applied Research Network” to coordinate sequestration R\&D among various institutions and stakeholders (Goel et al. 2021b). Under the National Action Plan on Climate Change (NAPCC) 
2008, Government of India (GOI) proposed the $9^{\text {th }}$ mission for Clean Coal Technology (CCT). Bharat Heavy Electrical Limited (BHEL) collaborated with Tiruchi Regional Engineering College-Science and Technology Entrepreneurs Park (TREC-STEP) and organized four skill leverage and training programs on CCT-CCS in 2011-2012. The programs were funded by the European Union and implemented the initiatives of the $9^{\text {th }}$ mission (Goel et al. 2021b).

Besides, DST and the Research Council of Norway (RCN) commenced a joint programme to research climate change, including an innovative domain of metal-organic framework (MOFs) in Indian Institute of Petroleum, Dehradun (Uttarakhand). MOFs are used in adsorption technologies during post-combustion capture (TERI 2013; Goel et al. 2021b). Climate change research is also one of the thrust areas of research under the Norwegian Program for Research Cooperation in India (INDNOR) (RCN 2018). In 2008, a joint meeting was held amongst DST, Department of Environment, Food and Rural Affairs (DEFRA, UK) and the Integrated Research for Action and Development (an Indian NGO). An Indo-US CCS research programme has also been initiated and is the most active collaboration working in the field. DST established an independent network to study CCS in India named ICOSAR (Shackley and Verma, 2008). Maulana Azad National Institute of Technology (MANIT), Bhopal became the first Indian Institute to start a dedicated course on carbon sequestration (Goel et al. 2021b).

Under MI, DST and DBT have launched Carbon Capture Innovation Challenge whose scope is to enable emission intensive industries and sources to move towards near-zero $\mathrm{CO}_{2}$ emissions. A call was launched in 2018 for joint R\&D with other MI member countries to identify breakthrough technologies in CCUS. Under this, 17 proposals were recommended from DST and 3 from DBT (MSTGOI 2018). The list of the supported projects (19) in 2019-20 can be found in 
(https://dst.gov.in/sites/default/files/List\%20of\%20CCUS\%20projects\%20supported\%20under\% 20Mission\%20Innovation\%20IC3\%20F.Y.\%202019-20\%20 1.pdf).

CCS initiatives got more R\&D support from the Government when it became a part of Mission Innovation along with European Union and 21 other countries in 2015 (Goel et al. 2021). The most promising research and technological developments in India in the last two decades have been elucidated below (Fig. 8).

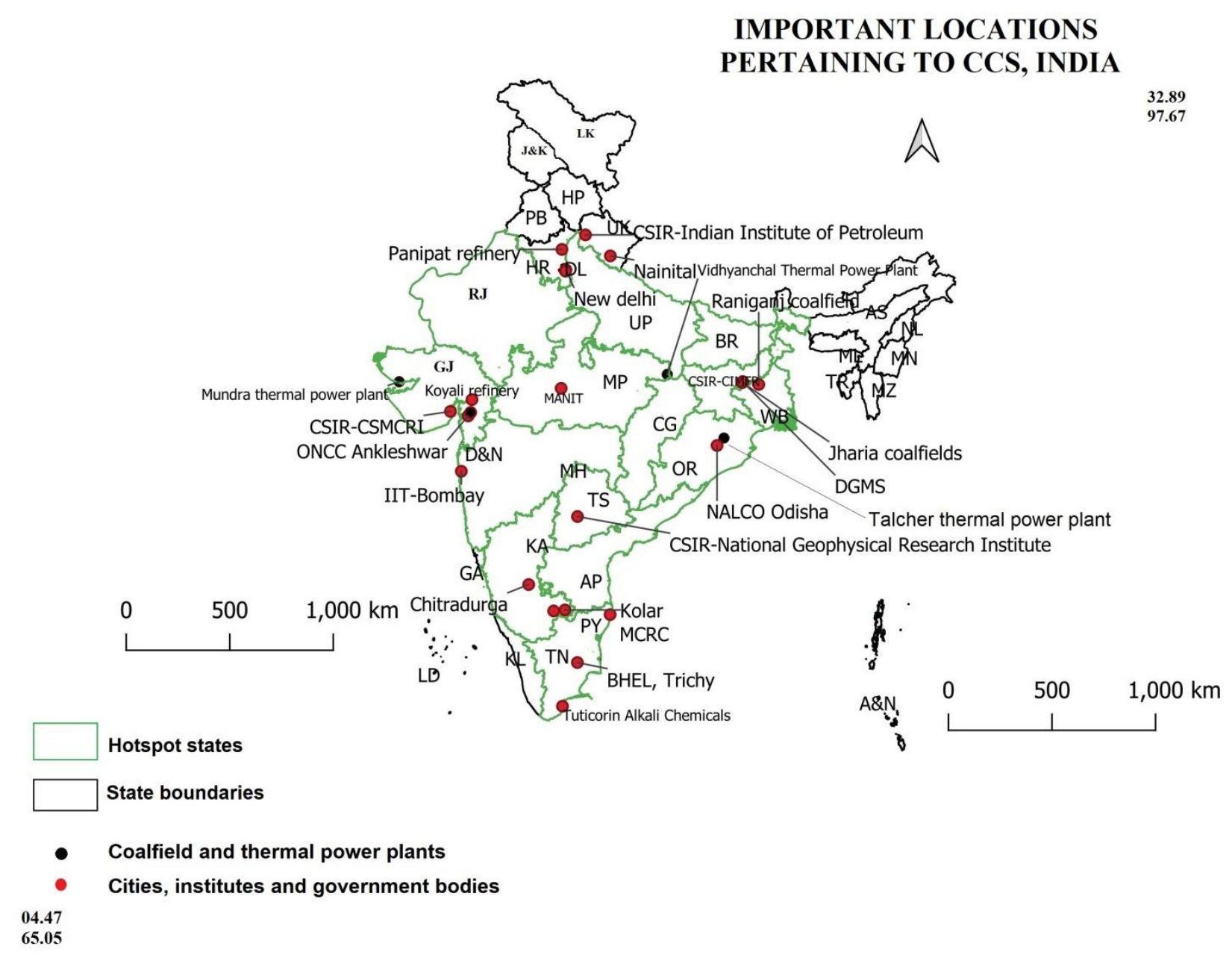

Fig 8. India map showing important locations mentioned in the work.

- Several Indian Public Sector Units also came forward. For example, the Oil and Natural Gas Commission (ONGC) expressed interest to establish an EOR project to increase the 
crude oil extraction from the Ankleshwar oil field, Gujarat (Kumar et al. 2018; Kumar et al. 2020). The plan was to transport $\mathrm{CO}_{2}$ from the Hazira processing plant (Gujarat) to the depleted onshore reserve of Ankleshwar to enhance the oil recovery (Chakroborty 2008 as referred in TERI, 2013).

- A pilot reactor was set up at Hazira processing plant to use the captured $\mathrm{CO}_{2}$ for microalgal growth which were later used for production of biogas. Two different setups were studied. In one setup, only Chlorella sp. was used while the other had a consortium of Chlorococcumhumicola, Scenedesmus quadricaudaand Chlorellavulgaris. The average $\mathrm{CO}_{2}$ capture and yield rate of these microalgae was $30 \mathrm{~g} \mathrm{CO}^{2} \mathrm{~m}^{-2}$ day $^{-1}$ and $18 \mathrm{~g}$ $\mathrm{m}^{-2}$ day $^{-1}$, respectively. The mean $\mathrm{CH}_{4}$ yield stood at 386 litres $\mathrm{CH}_{4} \mathrm{~kg}^{-1}$ and $228 \mathrm{CH}_{4} \mathrm{~kg}$ ${ }^{1}$ for the Chlorella sp. and the consortium respectively.

- In 2012, the Department of Atomic Energy (DAE) led a consortium with BHEL, National Thermal Power Corporation (NTPC) and Indira Gandhi Centre for Atomic Research (IGCAR) to develop ultra-supercritical technology for thermal power plants (Goel et al. 2021b).

- Coal India Limited (CIL) and the Geological Survey of India (GSI) collaborated to study the feasibility of Indian un-mineable coal seams for sequestration through ECBMR (Goel et al. 2021b).

- Central Institute of Mining and Fuel Research (CIMFR), Dhanbad initiated research in the $\mathrm{CO}_{2}$ storage potential of Peninsular India (Goel et al. 2021b). The National Thermal Power Corporation (NTPC) in association with NGRI and Battelle Pacific North-West National Laboratory (USA) has been working on the feasibility of the Deccan trap basaltic rocks as a carbon sequestration site (as referred in TERI 2013; Goel et al. 2021b). 
They used borehole data. Seismic approaches were of not much use since Deccan trap appeared opaque seismically (Goel 2008). Notwithstanding, Kumar et al. (2008) chalked out methodologies for a pilot study for CCS in the Deccan trap.

- The Indian premier educational and research institutes are actively working in the field of CCS. A collaboration amongst IIT Bombay, Indian Institute of Petroleum (IIP), Central Salt \& Marine Chemicals Research Institute (CSMCRI) and the National Environmental Engineering Research Institute (NEERI) is actively working on adsorbents aimed at postcombustion capture for $\mathrm{CO}_{2}$ (TERI, 2013). IIP boosted research in developing postcombustion capture technologies such as amine-based adsorbents and ionic solvents (Goel et al. 2021b).

- National Aluminium Corporation (NALCO) is aiming for bio-sequestration with its coalpowered plant in Orissa. It has involved a high-end bio-technology company, Indo-Can Technology Solutions (ICTS) to achieve its objectives. The bio-sequestration will be executed by algae, which will be cultivated within a pond, enclosed in a 0.18 -acre area. The flue gas, after being cooled, will be fed in the pond, which would accelerate the growth of algae. The microalgae will later be retrieved for producing biofuel. In this pilot project, the theoretical maximum production of biomass stood at $291.5 \mathrm{t} \mathrm{h}^{-1} \mathrm{yr}^{-1}$ (Pradhan et al. 2017). A demonstration plant at the Indian Oil Corporation Limited (IOCL) is under construction near the Panipat refinery (Haryana). It would capture industrial $\mathrm{CO}_{2}$ and covert into ethanol $\left(\mathrm{C}_{2} \mathrm{H}_{5} \mathrm{OH}\right)$ and 2,3-Butanediol $\left(\mathrm{C}_{4} \mathrm{H}_{10} \mathrm{O}_{2} ;\right.$ Ray 2021). Viswanathan and Sudhakar (2019) reviewed the potential of microalgae in CCUS and concluded that microalgae have huge potential in biofuel production, wastewater treatment and bioremediation. Such biotic fuel manufacture options will be especially helpful in 
meeting India's fuel demand and play a major role in helping India achieve its INDC targets (Ray 2021).

- Seshadri and Shashirekha (2018) conducted a seven-year preliminary study in the Murugappa Chettiar Research Centre (MCRC) on the bio-sequestration potential of Scenedesmus, an algal species. Two different waste streams were used. Liquid waste from a sugar mill and $\mathrm{CO}_{2}$-rich gaseous waste from a distillery leads to consumption of $6000 \mathrm{~m}^{3}$ and production of (300-500) gram $/ \mathrm{m}^{3} /$ day of algal biomass. If the process is scaled up this could lead to the sequestration of $1500 \mathrm{t} \mathrm{Cha}^{-1} \mathrm{yr}^{-1}$ and production of 100 tonnes of biomass per hectare annually. This biomass can be used in several ways as mentioned in the previous paragraph.

- The Department of Chemical Engineering, IIT Bombay has been researching cyanobacteria to develop them as cell factories that can convert atmospheric $\mathrm{CO}_{2}$, into useful products such as biofuel (TERI, 2013). However, such work is in a nascent stage and more research is needed (Mondal et al. 2017).

- IIT-Bombay has been a pioneering institute in exploring the possibilities of $\mathrm{CO}_{2}$ ECBMR. Studies by Prof. Vikram Vishal and his team (Section 5.2) have established a strong case for ECBMR in the Gondwana coal blocks.

- BHEL under the direction of DST established a 'Centre for Excellence in Coal Research'. Under this initiative, BHEL provided a roadmap for oxy-fuel combustion research (Goel et al. 2021b). Bharat Heavy Electrical Limited (BHEL) has also established a 6.5 MW IGCC power plant to study and implement the prospects of precombustion capture technologies in India. However, a minimum capacity of $100 \mathrm{MW}$ is 
to be experimented with to understand the nuances such as system optimization and hot gas clean-up (Sethi, 2017).

- The company CarbonClean (India) has come up with an innovative technology that converts the emitted $\mathrm{CO}_{2}$ into baking soda. The firm, which comprises two chemists from IIT Kharagpur, who are also the inventors of the technology. The technology is currently installed in Tuticorin Alkali Chemicals, without subsidy, and can utilise 60,000 tonnes of $\mathrm{CO}_{2}$ per year. The latest addition to its steam boilers has already led to zero $\mathrm{CO}_{2}$ emission from the plant- a crucial breakthrough (Harrabin 2017).

- In IIT Delhi, Subbarao et al. (2018) have patented a water scrubbing-based technology. It can produce bio-methane from biogas with $>95 \%$ methane concentration. This can act as a substitute fuel for vehicles running on natural gas, such as the CNG autorickshaws. They can also be injected into the natural gas grid. The process of water scrubbing also produces Bio- $\mathrm{CO}_{2}$ as a by-product. This $\mathrm{BioCO}_{2}$ can be used for algae cultivation, production of $\mathrm{CaCO}_{3}$ and dry ice. Besides, it can be a natural alternative to synthetic $\mathrm{CO}_{2}$.

- Tripathi (2018) conducted an experimental study to understand the effect of increased atmospheric $\mathrm{CO}_{2}$ level of $585 \mathrm{ppm}$, which is being projected to reach by 2060 , under the business-as-usual scenario (Smith and Myers, 2018). The plant chosen was rice. The experiment was conducted in a free-air $\mathrm{CO}_{2}$ enrichment ring under two scenarios- at the ambient value of $400 \mathrm{ppm}$ and the predicted value of $585 \mathrm{ppm}$. It was observed that the photosynthesis rate, leaf area per plant and leaf area index increased in the latter conditions. However, the effects can be seen in terms of nutritional deficiency in the plant. For example, Smith and Myers (2018) stated that by 2050, important crops can have a $3-17 \%$ nutritional deficiency in iron, zinc and protein. 
- Nahar and Verma (2018) designed India's first carbon footprint calculator where both household and individual emissions can be calculated. This calculator was reviewed by Certified Energy Manager of Bureau for Energy Efficient (BEE). The "Yo! Green" Calculator also provides a proactive action plan that can be taken in day-to-day life to reduce emission footprint.

- Neyveli Lignite Corporation Limited (NLCIL) and Pondicherry Engineering College have developed a novel method called "Biomarker algal immobilization technique for accelerating absorption". The method combined with photo bio-reaction has the ability to absorb all the $\mathrm{CO}_{2}$ emission from power plants (Ranjan et al. 2018).

- Kumar et al. (2020) reviewed the status of CCS studies from the Deccan traps as follows. CCS by natural means has taken place in the Deccan trap. This is indicated by the specific association of rock types (limestone and inter-calcareous facies below and between lava flows). Tholeiitic basalt lava flows of the Mandla area are a potential site for long-term $\mathrm{CO}_{2}$ storage. Deccan basalt water- $\mathrm{CO}_{2}$ saturated experiments prove partial and complete carbonation reactions.

Kumar et al. (2008) pointed out that even though the Deccan trap basalts and the Columbia River Basalts resemble chemically and mineralogically, the scientific deductions on the latter regarding the CCS has not worked out for the Decca trap-rocks. This means that the in-situ rock testing and determination of properties will be the key step ahead. Similarly, McGrail et al. (2008) stated that carbonation rates in basalt samples vary significantly in India, USA and African basalts despite resembling mineralogy and chemistry. 
- NTPC under its NTPC Energy Technology Research Alliance (NETRA) scheme has initiated research in carbon sequestration. One such programme includes the setting up of a $10 \mathrm{MW} \mathrm{CO}_{2}$ capture plant. The pre-feasibility study of this plant was conducted by IITBombay and Carbon Clean Solutions Limited. The gas would be captured from the flue gas and will be used in producing soda ash, methanol, and urea (IEA 2020a; Goel et al. 2021b). NETRA also signed an MOU with ONGC to set up a carbon capture plant at the Jhanor Gandhar thermal power plant (Gujarat). The captured $\mathrm{CO}_{2}$ will be used for EOR in ONGC's Jhanor oil field (IEA 2020a). Other such projects include capturing $\mathrm{CO}_{2}$ from Cuddalore power plant under IL\&FS Tamil Nadu Power Company Limited (ITPCL) and using it for EOR in oilfields in Kamalapuram and other oil fields in Cauvery basin (Ranjan et al. 2018).

- An EOR demonstration project is under evaluation by ONGC and IOCL to capture $\mathrm{CO}_{2}$ from the Koyali refinery (Gujarat). The captured $\mathrm{CO}_{2}$ will be used for EOR in the Gandhar Oil Field (Gujarat). The feasibility study is being carried out by the Institute of Reservoir Studies, ONGC (Goel et al. 2021b). IIT Bombay along with Upstream for Carbon capture, a taskforce under Ministry of Petroleum and Natural Gas, are the knowledge partners in the project (V. Vishal, per. comm.). Apart from this individual study, ONGC is also hiring consultants for conducting overarching carbon capture and transportation. After this, the point sources will be ranked according to their economic feasibility in capturing and transporting $\mathrm{CO}_{2}$ for EOR (Ranjan et al. 2018).

- A collaboration between Central Electricity Authority (CEA), Bureau for Energy Efficient (BEE) and Germany aimed at assessing emissions from Thermal Power Plants and consequent remedial measures (Goel et al. 2021b). 
- Since 2009, Climate Change Research Institute (CCRI), an NGO, has been organizing capacity development courses, training, and workshops in the field of CCS. They have been supported by the GOI and private sector.

- A Memorandum of Understanding (MoU) was signed between Jawaharlal Nehru Centre for Advanced Scientific Research (JNCASR, Bangalore) and the Breath Applied Sciences, a JNCASR-raised company, was signed on 05-June-2020. The MoU aims technology transfer for converting $\mathrm{CO}_{2}$ to methanol. The pilot mode can convert up to $300 \mathrm{~kg} \mathrm{day}^{-1}$, but its capacity can be increased to $500 \mathrm{~T} \mathrm{day}^{-1}$ at an industrial-scale. Tata Steel wishes to adopt the technology into their plants (DST 2020a).

- In the transport sector, the GOI is working to increase renewable energy capacity especially in the railway due to their high consumption of electricity. To reduce emissions, the GOI decided to skip the Bharat V and directly implement Bharat VI emission standards in 2020 (Senthilkumar 2021).

- Indian Oil Corporation Ltd has partnered with US-based Dastur International, Air Liquide and Bureau of Economic Geology at the University of Texas (UT) at Austin to carry out a CCUS feasibility study at its Koyali refinery (Gujarat). The carbon capture capacity would be $13.7 \mathrm{MT} \mathrm{y}^{-1}$. This will be India's largest CCUS project. The captured $\mathrm{CO}_{2}$ would be used for EOR in ONGC's Gandhar Oil field (Gujarat). The captured would also be used in the food and beverage industry (Gupta 2021). NTPC and IIT-Bombay have partnered to conduct feasibility studies on the conversion of captured carbon into fuels, fertilizers, urea etc (Ranjan et al. 2018; other utilization pathways in Fig. S11).

- Coal-India Ltd. has floated global tenders to set up a coal to methanol plant in Dankuni (West Bengal). The bids have been invited for a build-own-operate model. The 
investment is around USD 800 Million. 0.67 MT of methanol is expected to be produced annually (Vishal et al. 2021).

- Dalmia cement became the first cement company in the world to launch an ambitious plan of becoming "carbon negative by 2040" (GCCSI 2019). In line with this, they have announced to build a carbon capture plant with a $0.5 \mathrm{MT}_{\text {year }}{ }^{-1}$ capacity in Tamil Nadu production plant. The technological expertise would be provided by Carbon Clean Solutions Limited, a UK based company (Rumayor et al. 2021).

- Department of Science and Technology, GoI, has sanctioned the establishment of the National Centre of Excellence in Carbon Capture and Utilization (NCoE-CCU) at IIT Bombay (Vikram Vishal, personal communication).

All the R\&D and technologies mentioned are at various levels of readiness and hence would take different amounts of times to scale-up. Vishal et al. (2021) ascertained the Technology Readiness Levels (TRLs) of various CCUS technologies and compared their status with the global state of the art equivalent (Fig. S12).

\subsection{The probable cost of CCS implementation in India}

The primary cost in CCS is in the domain of carbon capture, accounting for $60-80 \%$ of the total CCS system costs (IEA 2008). However, in India such a study has not been undertaken to check the feasibility of CCS cost as a whole, however, the cost of retrofitting of existing coal power plants with capture technology has been simulated. Based on technologies available in 2010, $\mathrm{CO}_{2}$ capture in a power-plant would have increased the cost of electricity by $25-50 \%$ (Nanoni and Goswami 2010). Rao and Kumar (2014) using the Integrated Environmental Control Model 
(IECM), did a more detailed analysis. The study was conducted on four thermal power plants viz., in Trombay (Maharashtra), Ramagundam (Telengana), Dahanu (Maharashtra) and Badarpur (Delhi). The plants were chosen for their proximity to a potential carbon sink. The model was simulated for a post-combustion capture scenario using a monoethanolamine-based system, as it was the cheapest. The simulation study pointed out an increased expenditure of electricity production by INR $2.2-2.6$ per $\mathrm{kWh}$. This rate of increase is in the range of $63-76 \%$ of the current production rate. The present average rate of production is INR $3.38-3.45$ per $\mathrm{kWh}$. This increase in expenditure would mean that electricity production would have to be increased to cover the extra cost.

An indirect approach by Anandarajah and Gambhir (2014) provides a different perspective in this regard. In the study, two low carbon scenarios were analyzed (L1, L2) using a costoptimization model called TIAM-UCL. L1 included CCS while L2 did not. It was found that in case of L2, emission level would decrease with greater contribution from renewables to compensate for the lack of CCS technologies. This, however, triples the marginal emission abatement cost till 2050 in L2 than L1. Thus, the cost of including CCS in India's climate policies (L1) will be beneficial in the long run, whereas solely depending on renewables (L2) would incur more expenditure.

\subsection{Potential sites and methods of carbon sequestration in India}

\subsubsection{India's sedimentary basins:}


India has a total of 26 sedimentary basins. These basins, covering $\sim 3.14$ million $\mathrm{km}^{2}$ area, are of two distinct types based on whether they are up to or beyond the $200 \mathrm{~m}$ isobaths. The basin on the land up to $200 \mathrm{~m}$ isobaths line cover $\sim 1.79$ million $\mathrm{km}^{2}$ while, basin area beyond the $200 \mathrm{~m}$ isobaths covers $\sim 1.35$ million $\mathrm{km}^{2}$. These basins have an estimated potential ranging from 500 GT to 1000 GT (Kalbende2015). The 26 basins have been classed into five categories depending on their hydrocarbon prospects (Table 7; Kalbende 2015).

Holloway et al. (2008) stated that the Indian Purana/Proterozoic sedimentary basins e.g., Cuddapah, Chhattisgarh and Vindhyan have quite limited porosity and permeability data and therefore for the time being will not be suitable sites for $\mathrm{CO}_{2}$ sequestration. Bhandari et al. (2008) considered the Ganges, the Vindhyan and the Rajasthan basins are suitable sites for $\mathrm{CO}_{2}$ sequestration. These authors also stated that at two locations Palwal (Haryana) and Tumsar (Maharashtra), deep aquifers have been studied and that more studies are needed to confirm whether these can be good locations for sequestration.

Table 7. Categorisation of Indian sedimentary basins based on their hydrocarbon prospects (compiled from Kalbende 2015).

\begin{tabular}{|l|l|l|l|}
\hline Category & Area $\left(\right.$ in $\left.\mathbf{~ k m}^{2}\right)$ & Status & Regions \\
\hline
\end{tabular}




\begin{tabular}{|c|c|c|c|}
\hline Category 1 & 518500 & Commercially established & $\begin{array}{l}\text { Assam shelf, Krishna-Godavari, } \\
\text { Assam-Arakan belt, Rajasthan, } \\
\text { Cauvery, Assam shelf and } \\
\text { Cambay. }\end{array}$ \\
\hline Category 2 & 164000 & $\begin{array}{l}\text { Prospective, but no production on } \\
\text { a commercial scale }\end{array}$ & $\begin{array}{l}\text { Mahanadi north-east coast, } \\
\text { Kutch, and Andaman \& Nicobar }\end{array}$ \\
\hline Category 3 & 641000 & $\begin{array}{l}\text { Research and development } \\
\text { underway to ascertain prospects }\end{array}$ & $\begin{array}{l}\text { Kerala-Konkan, Himalayan } \\
\text { foreland, Vindhyas, Saurashtra, } \\
\text { Ganga basin and Bengal }\end{array}$ \\
\hline Category 4 & 461200 & Uncertain prospects & $\begin{array}{l}\text { Pranhita-Godavari, } \\
\text { Chhattisgarh, Bastar, Rewa- } \\
\text { Damodar, Satpura south, Spiti- } \\
\text { Zanskar, Karewa, Cuddapah, } \\
\text { Deccan syncline, Narmada } \\
\text { \&Bhima-Kaladgi. }\end{array}$ \\
\hline Deep-water & 1350000 & Unexplored & $\begin{array}{l}400 \text { metres till EEZ (exclusive } \\
\text { economic zone). }\end{array}$ \\
\hline
\end{tabular}

\subsubsection{Storage potential of geological formations}

The country has an estimated storage potential of 500-1000 BT. The deep saline aquifer formations have the highest potential of 300-400 BT followed by the Deccan trap basaltic rocks 
(200-400 BT), un-mineable coal seams ( 5 BT) and exhausted hydrocarbon reservoirs (5-10 BT) (Kalpende 2015). These estimates were made using empirical equations in which the areas geographical, geochemical, and geological characteristics were taken into consideration (Singh et al. 2006). Fig. 9 presents the sequestration potential and suitable zones. The 5,00,000 $\mathrm{km}^{2}$ region in the north-western Deccan trap (Mukherjee et al. 2017; Mukherjee et al. 2020) seems to be a promising prospect with storage capacities up to 400 GT. Holloway et al. (2008) however pointed out that the Deccan trap and the Rajmahal trap basalts are unsuitable because of the present-day technological issues. Deccan trap consists of thick lava flows, mostly > $3000 \mathrm{~m}$ thick at the western flank. The Saurashtra region (southern Gujarat) largely meets the prerequisites for carbon sequestration (Kumar et al. 2008). Research and developments are still underway. Geochemical, geophysical, and fluid-rock behaviour modelling of the area needs to be conducted to test the viability of the region as a sequestration zone. A study by Punnam et al. (2021) concludes that at an optimal injection rate, $\mathrm{CO}_{2}$ can be sequestered efficiently through residual and structural trapping mechanisms if optimal injection points are chosen. 


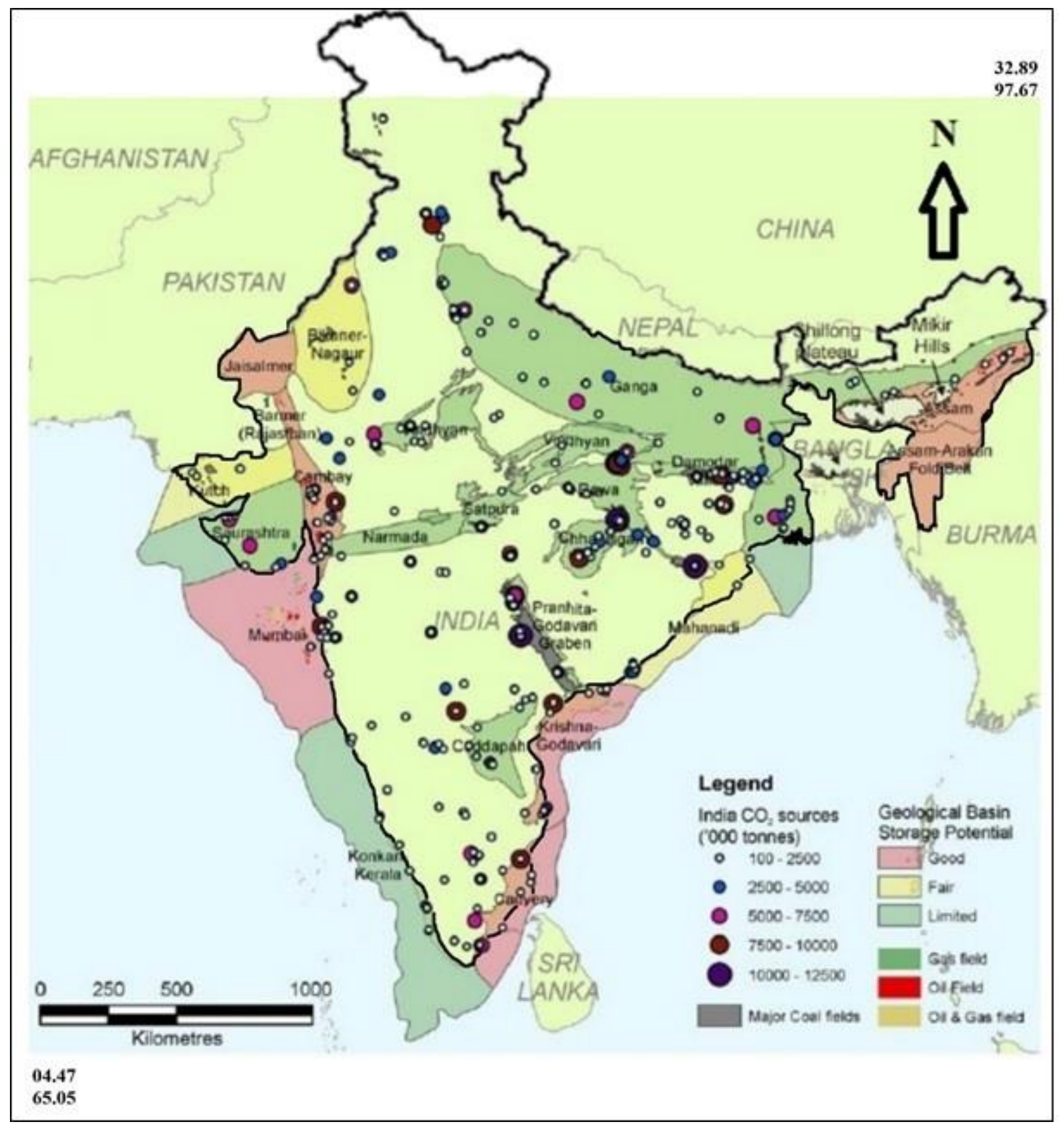

Fig 9. $\mathrm{CO}_{2}$ sources and geological sequestration zones of India. Modified from fig. 1 of IEA (2008).

Kumar et al. (2008) chalked out methodologies for a pilot study for CCS in the Deccan trap.

These include: 
- Feasibility studies in areas with a thickness of $\sim 800 \mathrm{~m}$, including adsorbed soil gas surveys (ASGSs), drill location studies and Magneto-telluric analysis

- Modelling and simulation for borehole drilling and subsequent $\mathrm{CO}_{2}$ injection

- Actual drilling and injection of $\mathrm{CO}_{2}$ at a rate of $\sim 100$ tonnes per day at $2000 \mathrm{psi}$. This should be done for 10 days

- Monitoring and analysis of results including verification for mineralization using observation boreholes

Singh (2008) identified the potential coal-bearing basins and calculated their sequestration potential using empirical equations. The author suggests that proximate analysis and vitrinite reflectance percentage are suitable parameters to estimate the sequestration potential of the coal beds. Table 8 summarizes the coal-bearing basins along with their potential capacity for sequestration.

Table 8. Coal bearing basins along with their potential sequestration capacity (compiled from Singh 2008).

Sequestration

Coalfields

Cambay Basin

Barmer Sanchor Basin $\quad 1853.28$

West Bengal Gangetic $\quad 260.88$ capacity (MT)

2094.45

Coalfields

Talcher

Sohagpur

South Karanpura
Sequestration

capacity (MT)
41.18

40.76

36.33 
Plain

$\begin{array}{lclc}\text { Birbhum Coalfield } & 168.46 & \text { Domra Panagarh } & 32.45 \\ \text { Talcher } & 97.49 & \text { Kamptee extension } & 19.42 \\ \text { East Bokaro } & 84.94 & \text { Wardha Valley extension } & 13.11 \\ \text { Godavari } & 75.28 & \text { Mand Raigarh } & 2.97 \\ \text { Jharia } & 71.2 & \text { Singrauli } & 1.46 \\ \text { Raniganj } & 46.19 & \text { Total } & 4752.17\end{array}$

Deep saline aquifers also hold considerable potential around Gujarat and Rajasthan coastal area, especially in the Ankleshwar oil field (Section 5.1). The Ganga foreland basin is considered a potential site for sequestration. The fluvial sandstones of the Siwalik formations hold good sequestration potentials (Section 5.3). The region is capped by siltstone having low permeability, thus not allowing any large-scale movement through it. This eliminates the chance of $\mathrm{CO}_{2}$ escape to the atmosphere, which is one of the hindrances in choosing a site. Further, the foreland is near few large-scale point sources thus sequestration in the nearby region can reduce the transport cost (Holloway et al. 2009; Kalbende 2015). The storage potential described, however, seems to be underestimated (for coal) and overestimated (for saline aquifers) (Singh et al. 2021). The reason given by Singh et al (2021) states that while the estimation methods for saline aquifers was largely borrowed from the methods used by United States Department of Energy (US DOE), the estimated methods for coal formations assumed higher coal consumption and hence less area for sequestration. Thus, it was suggested that estimations be made in a fresh manner.

The latest initiative in calculating the $\mathrm{CO}_{2}$ storage capacity of India's geological formations was undertaken by Vishal et al. (2021). Based on the global assessment methods, a systematic 
theoritical assessment was made. The estimations were made for four storage pathways viz. deep saline aquifers (291 GT), basaltic rocks (97 - 316 GT), ECBMR (3.7 GT) and EOR (3.4 GT).

\subsection{Terrestrial carbon sequestration in India}

Terrestrial carbon sequestration (Section 2.4.2b) is a form of biotic sequestration that has immense potential in India. Soil stores both organic and inorganic carbon in the form of biomass and pedogenic $\mathrm{CaCO}_{3}$, respectively. $\mathrm{Lal}$ (2004) presented a detailed analysis of the sequestration potential of the Indian soils. The organic carbon pool of the soil was estimated at 2.1 BT up to 30 $\mathrm{cm}$ depth and $6.3 \mathrm{BT}$ up to $150 \mathrm{~cm}$ depth. The inorganic carbon pool was estimated at $19.6 \mathrm{BT}$ up to $100 \mathrm{~cm}$ depth. However, in another work (Pal et al. 2015), significant different magnitudes, 2.997 BT and 3.403 BT, have been estimated up to $150 \mathrm{~cm}$ depth. Although the numbers differ widely, the sequestration potential of Indian soil and trees in general are significant. GOI launched Green India Mission (GIM) under NAPCC to harness this potential in urban and peri-

urban areas. The NIM aims to enhance the green cover across $2000 \mathrm{~km}^{2}$ of urban and peri-urban areas (Govindaraju et al. 2021). The mangroves particularly are considered to have 50 times more sequestration potential than the terrestrial trees because they allocate more carbon below ground than the latter (Bhatt and Kathiresan 2012; Alongi 2014).

Using stratified random sampling, Pandey and Pandey (2013) estimated the carbon sequestered by the mangroves in Gujarat (India) using 316 plots of $10 \mathrm{~m} * 100 \mathrm{~m}$. This constitutes $\sim 0.03 \%$ of the total mangrove area. The total value came out to be $8.116 \mathrm{MT}$ of carbon. The study by Sahu et al. (2016) in the Mahanadi mangrove delta, using Pandey and Pandey's (2013) methodology yielded a magnitude of 0.977 MT. A more comprehensive study conducted by Rani et al. (2021) 
using radiocarbon dating of three stations in the Cochin estuary (Kerala). These cores were then analysed for the C-13 and N-15 isotopes, along with organic carbon, nitrogen content and bulk density. The calculated organic and inorganic carbon sequestration rate in the Cochin mangroves was estimated to be $2.95 \mathrm{t} \mathrm{C} \mathrm{ha}^{-1} \mathrm{yr}^{-1}$.

Like natural vegetation, agricultural techniques such as agroforestry were recognised under the Kyoto Protocol (1997) for their sequestration potential (Nair et al. 2009; Abbas et al. 2017). It is even a more lucrative option in a country like India, due to scarcity of land resources. Agroforestry techniques combine forest and agricultural produce on the same land, thus significantly enhance farmer's income and promoting biodiversity (Pandey 2007). Their sequestration potential is also significant. In a tree-crop combination, biomass per unit of water significantly increases leading to more carbon sequestration. A study conducted in 51 districts across 16 Indian states estimates that the sequestration potential of the agroforestry systems of these states to be 7.23 MT (Dhyani et al. 2020's review).

Yadava (2010) assessed the carbon stock of soils in Manipur. Vegetation type and environmental factors govern the pool, emissions, and sequestration of the soil. The output showed that the pine forests had the largest carbon stock $\left(295.00 \mathrm{t} \mathrm{C} \mathrm{ha}^{-1}\right)$, followed by oak $\left(65.11 \mathrm{t} \mathrm{C} \mathrm{ha}^{-1}\right.$ to $127.52 \mathrm{t}$ $\mathrm{C} \mathrm{ha}^{-1}$ ), and Dipterocarpus (3.21 $\mathrm{t} \mathrm{C} \mathrm{ha}^{-1}$ to $3.77 \mathrm{t} \mathrm{C} \mathrm{ha}^{-1}$ ). Soil has its natural carbon content. Its degradation releases this locked-up carbon into the atmosphere. Soil degradation is already a widespread issue in India. Yadava and Thokchom (2021) conducted a study to ascertain the $\mathrm{CO}_{2}$ loss due to soil degradation. Three different Dipterocarpus forest sites with dissimilar conditions were chosen in the Chandel district (Manipur). Site 1 was the control site, site 2 was a recently 
logged site (underwent logging a month before sampling) and site 3 was slashed and burned (underwent burning a year before sample collection). 12 samples were collected from each site between September 2017 and August 2018. The depth of collection ranged 0 to $10 \mathrm{~cm}$ below the ground level. The $\mathrm{CO}_{2}$ loss rate was estimated using the alkali absorption method. The rate varied between 263.5 to $609.9 \mathrm{mg} \mathrm{CO}_{2} \mathrm{~m}^{-2} \mathrm{hr}^{-1}$ at site $1,233.4$ to594.8 $\mathrm{mg} \mathrm{CO}_{2} \mathrm{~m}^{-2} \mathrm{hr}^{-1}$ at site 2 and 308.7 to $700.2 \mathrm{mg} \mathrm{CO}_{2} \mathrm{~m}^{-2} \mathrm{hr}^{-1}$ at site 3 . The mean values at these sites stood at $330.74 \pm$ $2.16,308.36 \pm 2.06$ and $388.97 \pm 1.96$, respectively. The highest value of $\mathrm{CO}_{2}$ loss was observed in the burnt area due to rapid degradation caused by initial burning, which caused more microbial activities hence augmented decomposition and enhanced $\mathrm{CO}_{2}$ flux.

Ragula and Chandra (2020) calculated the C stock of roadside trees in Bilaspur (Chattisgarh state). Five sample plots (100 m x $10 \mathrm{~m}$ ) were selected in six zones within the city. The $\mathrm{C}$ stock was calculated empirically, and the total value stood at $148.18 \mathrm{t}$ C. (Raha et al. 2020) assessed the C stock of three distinct forest types in Sagar district in Madhya Pradesh. The chosen forest types were Boswellia Forest, Dry deciduous teak forest and Dry deciduous mixed forest. Random sampling was carried out by placing 42 quadrats (60 $\mathrm{m} \times 20 \mathrm{~m}) ; 14$ in each forest. The $\mathrm{C}$ stock was calculated to be $75.3 \pm 6.1 \mathrm{t} \mathrm{C} \mathrm{ha}^{-1}$ in Dry deciduous teak forest, $81.3 \pm 5.6 \mathrm{t} \mathrm{Cha}^{-1}$ in Dry deciduous mixed forest and $104.7 \pm 5.4 \mathrm{t} \mathrm{C} \mathrm{ha}^{-1}$ in Boswellia Forest. (Moharana et al. 2021) conducted a similar study to ascertain the soil C stock in the Suratgarh block of Rajasthan. Before 1960s, the study area was desert land however due to canal intervention in the last 1960s, the area became suitable for agriculture. Moharana et al. (2021) collected 150 soil samples from 4 LULC types (single crop, double crop, plantation crop and sand dunes). The soil samples were collected from surface up to $90 \mathrm{~cm}$ in depth and geostatistical analysis was conducted to 
calculate the soil $\mathrm{C}$ stock. The soil $\mathrm{C}$ stock stood at $92.25 \mathrm{t} \mathrm{C} \mathrm{ha}^{-1}$. This shows that restoring desert lands can also help in sequestering carbon. Mir et al. (2021) calculated the C stock of community managed forests in Khasi hills of Meghalaya. Fifteen such forests were analyzed. Sampling was done using a belt transect $(250 \mathrm{~m} \times 20 \mathrm{~m})$ in each forest. The $\mathrm{C}$ stock was calculated empirically. The total carbon stock was calculated at $107.53 \pm 9.7 \mathrm{t} \mathrm{C} \mathrm{ha}^{-1}$.

Kumar et al. (2021) took a composite approach to quantify the SOC in a part of Lahaul Valley, Himachal Pradesh. This treacherous Himalaya valley has a cold arid climate. Hence, the soil samples were only collected from the arable lands, from the surface up to a depth of $30 \mathrm{~cm}$. These samples were then tested using the rapid titration method to ascertain their SOC content. Ordinary kriging was undertaken to estimate the SOC content from unsampled locations. The average SOC content was estimated to be $14.41 \mathrm{~g} \mathrm{~kg}^{-1}$. Several other studies have been conducted in Western Himalayas (Tables S5, S6).

Govindaraju et al. (2021) conducted three studies in Neyveli Lignite Corporation Campus (NLCC) \& Reserve Forests of Panchamalai in Tamil Nadu and at the Delhi Ridge (Delhi). The study conducted in NLCC was to identify the most suitable sequestration species in and around the NLCC campus. The study concluded that Mangifera Indica (Mango tree) and Azadirachta $\underline{\text { Indica }}$ (Neem tree) are the most resilient trees that can grow around industrial areas along with having a significant sequestration potential. The study in Panchamalai aimed to find the sequestration potential of trees based on their altitude of growth. The study concluded that the reserve forests have stored 3081.41 tonnes of $\mathrm{CO}_{2}$. The most potential trees were found to grow at a 580-830 m altitude above the MSL. A case study estimated the total sequestration potential of green cover in Delhi to be $3.1 \mathrm{MT} \mathrm{y}^{-1}$. It also concludes that $\sim 90$ tonnes of $\mathrm{CO}_{2}$ per hectare 
could be released annually if the Delhi Ridge Forests face deforestation. Sharma et al. (2021)

calculated the sequestration potential of the trees in the Amity University Campus, Noida. A total of 1997 trees were enumerated, and their sequestration potentials were estimated empirically from the tree characteristics. The total annual sequestration was calculated to be 139.9 tonnes. Henry et al. (2013) and Cifuentes et al. (2015) have presented tree allometric equations and guidelines to use them. Table S7 summarizes other studies of estimating sequestration potential. Soil degradation is a key hindrance in sequestration. The five most affected states of such degradation are Mizoram, Himachal Pradesh, Kerala, Nagaland and Tripura with values of 89.2, $75,67.1,60$ and $59.9 \%$ of the degraded area with respect to their total geographical areas, respectively (Bhattacharya et al. 2015). However, soil can be restored by putting soil conservation and erosion control methods into practice. These conservation techniques if materialised could lead to a soil carbon sequestration potential of 30 BT (Pal et al. 2015).

\section{Case studies}

\subsection{Carbon sequestration potential through EOR pathway}

\subsubsection{General points}

$\mathrm{CO}_{2}$-EOR has been the first abiotic sequestration method that came into operation in the oil industry. Although the reasons were/are economic, it still acted as a sequestration method since the 1970s. The Kelly-snider oil field in Texas, USA was the first to use $\mathrm{CO}_{2}$-dependent EOR, using naturally occurring $\mathrm{CO}_{2}$ transported from New Mexico and Texas (USCOC 2012).

After the primary (unaided) recovery from the field, water is injected to maintain reservoir pressure. This water is brine, which is recovered from the reservoir during oil production and 
used for secondary recovery. $\mathrm{CO}_{2}$ is used in the tertiary recovery to further increase reservoir oil output. Secondary and primary recoveries hold prime importance for economic sustenance during oil extraction from reservoirs. During primary recovery, $\sim 20 \%$ of the total oil is recovered. Using secondary and tertiary recovery mechanisms can further increase production by 15 and $20 \%$, respectively, thus increasing the lifetime of an oil field. In the process, although $\mathrm{CO}_{2}$ is produced in the producer well, it is re-injected, and the total injected $\mathrm{CO}_{2}$ can stand 60\%. (Gozalpour et al. 2005; USCOC 2012).

\subsubsection{Sequestration potential at the Ankleshwar oil field (Gujarat)}

Unlike coal, India does not boast a dependable oil inventory. Seven Indian basins are presently under commercial operation ("category 1" row in Table 8). The total recoverable oil reserves of India as on 01-April-2020 stood at 603.6 MT and oil production in 2019-20 stood at 32.17 MT. The import value stood at 226.95 MT. Oil and related products amount to $27.1 \%$ of the total Indian imports in 2019-20 (GOI 2020b). This has been a major cause of India's trade deficit. This amount of oil import adds up to an incremental 300 MT of carbon that India imports (Ray 2021).

The Ankleshwar oilfield is a Cenozoic anticline having a deltaic origin and is located in the Cambay basin (Ganguli et al. 2016a; Ganguli et al. 2016; Surabhi et al. submitted). The Cambay basin contains a thick Paleogene sedimentary column deposited after Palaeocene over the Deccan traps (Srivastava et al. 2015; Ganguli et al. 2016a). The field has been under active production for about the last 56 years and has neared its maturity. As on April 2011, the total 
production from the oil field stood at $65.35 \mathrm{MT}$, which is $\sim 49 \%$ of the total reserves in place (Ganguli et al. 2016), along with a water cut value of 88\% (Ganguli et al. 2016b).

Ganguli (2017) developed a model to assess the carbon sequestration potential through the EOR pathway of this oil field. The initial datasets were provided by the ONGC.A similar EOR study was conducted earlier by Vendanti and Sen (2009), using in-situ combustion in the heavy oil field of Balol, also located in the Cambay basin (Ganguli et al. 2016a). The process of in-situ combustion means a certain part of heavy highly viscous oil undergoes combustion. The heat generated reduces viscosity and production increases. However, this study focussed on using seismic data to study fluid movement during different combustion phases.

Fracture pressure and pore pressure of the Ankleshwar Formation were calculated (Ganguli 2017) by using the equation of Mathew and Kelly (1967) and Eaton (1975; recent review by Dasgupta and Mukherjee 2020):

$P P=S_{V}-\left(S_{V}-P_{\text {hyd }}\right) X(D T n / D T)^{3}$ (eqn2)

$\mathrm{FP}=\mathrm{PP}+\left(\mathrm{S}_{\mathrm{h}} / \mathrm{Sv}\right) \mathrm{X}\left(\mathrm{S}_{\mathrm{v}}-\mathrm{PP}\right)$ (eqn3)

Here

PP: pore pressure

FP: fracture pressure

$\mathrm{S}_{\mathrm{V}}:$ vertical stress

$\mathrm{S}_{\mathrm{h}}:$ minimum horizontal stress

$P_{\text {hyd: hydrostatic pressure }}$

$\mathrm{DT}_{\mathrm{n}}$ : sonic travel time in shale 
DT: observed sonic travel time during well-logging

The result concluded that the Ankleshwar is a great potential field for carbon sequestration. The simulation shows that $\mathrm{CO}_{2}$ injection increases the oil recovery percentage from 56.8 to $71.6 \%$. It has a potential for safe sequestration of 15.04 MT along with a $10.4 \%$ increment in the oil production of the original reserves i.e., 134 MT (Ganguli et al. 2016a; Ganguli 2017).

\subsection{Coal seams and their sequestration potential through CBM recovery pathway}

\subsubsection{General points}

India has the third-largest coal reserves at 326.05 BT (Section 4) (GOI 2020a). The total production stood at 714.88 MT with surface mines accounting for $650.58 \mathrm{MT}$ and underground mines accounting for 64.3 MT (DGMS 2017) as referred in Singh and Hajra (2018). India's coal demand is expected to increase by $4.6 \%$ each year, which would put equal strain on its production (Finkelman et al. 2021). This strain manifested itself in October 2021 when the coal stock of India's several thermal power plants hit critically low levels. This led some states to impose partial load-shedding in order to compensate for it (Perumal 2021).

Coal can store a substantial amount of $\mathrm{CH}_{4}$, a greenhouse gas(Section 2.4.3b5). This has caused several related disasters in the past, the most recent one being in Pakistan where 23 mine workers died in the Marwar coalfield, Baluchistan province (RFERL 2018). Such disasters can be averted if the $\mathrm{CH}_{4}$ entrapped within the coal seams can be captured. The chemical properties of both the gases are such that while $\mathrm{CO}_{2}$ is adsorbed into the coal structure, it readily replaces the $\mathrm{CH}_{4}$ present there, thus also enhancing the production of $\mathrm{CH}_{4}$ (Vishal et al. 2012). 
In India, out of 326.05 BT of coal reserves, 99\% are the Gondwana coal, formed during the Permian Period and merely $1 \%$ are the Tertiary coal, formed during the Eocene Period. $88 \%$ of Gondwana coal is utilised in power generation. All kinds of coal contain $\mathrm{CH}_{4}$. In $\mathrm{CBMR}$, coals are classified based on their gassiness i.e., methane emitted per tonne of mined coal. (DGMS 1967) categorized underground coals (as surface coals lose their methane because of their exposure) into three degrees based on their gassiness; degree $\mathrm{I}\left(<1 \mathrm{~m}^{3}\right)$, degree II $\left(1-10 \mathrm{~m}^{3}\right)$ and degree III (> $10 \mathrm{~m}^{3}$ ). Out of 342 working underground coal mines all over India (DGMS2014), 242 are degree I, 90 are degree II and 13 are degree III.

The Jharia coalfield (Mukhopadhyay 2019) has been a major candidate in CBMR, with possibilities being considered for the last 15 years. Till now, the DGH has allotted 33 coal fields, covering an area of $26000 \mathrm{~km}^{2}$, for virgin coal bed methane recovery. Out of this, four have been operating since 2007; two in the Raniganj coalfield (Mukhopadhyay 2019) (operated by GEECL and EOL each), one in the Jharia coalfield (operated by ONGC) and one in the Sohagpur coal field (operated by RIL) (Vishal et al. 2012; Chatterjee and Paul 2016; Singh and Hajra 2018).

\subsubsection{Coal structure and behaviour:}

Coal is a sedimentary rock, formed under elevated pressure and temperature for geologically long periods. This results in coal displaying a dual-porosity structure, consisting of both macropores ( size $>50 \mathrm{~nm})$ and micropores $($ size $<2.0 \mathrm{~nm})($ Zdravkov et al. 2007). A difference in pore size also affects the flow of materials ( $\mathrm{such}$ as $\mathrm{CO}_{2}$ ) resulting in the application of 
different laws while studying such differential flows through the same medium. Gases follow Fick's law while diffusing through the micropores; and they follow Darcy's law while flowing through the coal cleats (Vishal et al. 2012, 2013a, 2018). $\mathrm{CO}_{2}$ injected into a coal body can stay in the cleats and micropores and lead to recovery of coal bed methane (Ribeiro e Sousa 2012).

$\mathrm{CO}_{2}$ sequestration in coal mines remained mostly a concept till $\sim 2012$ with only a few actual efforts made. Abandoned deep (> $500 \mathrm{~m}$ ) or ultra-deep (> $800 \mathrm{~m}$ ) mines that may be difficult to explore coal (Ribeiro e Sousa 2012) can be good targets for CCS. However, the leakage issue needs study in such cases as well (Piessens 2012). Vishal et al. (2013b) concluded that the permeability of Indian coal at low confinement decreases with injection pressure. However, permeability increases with higher confinements and higher injection pressures. Other studies by Vishal et al. (2017a,b) concluded that coal permeability is lower for $\mathrm{CO}_{2}$ in a supercritical phase than in its liquid phase. The reason can be attributed to the high affinity of coal for the supercritical variety. To overcome this, injection pressure induced fracturing can be used to counteract the swelling. However, it should be done in a controlled way such that the fracture does not propagate throughout the entire coal seam.

Vishal et al. $(2012,2013 a, 2018)$ simulated the sequestration potential through the ECBMR pathway. A simulator, COMET3, was employed to understand the behaviour of coal while sequestration, its capacity of sequestration and the extraction of $\mathrm{CH}_{4}$.

The numerical parameters of the simulated coal blocks and the model parameters are summarised in Tables 9 and 10, respectively. 
Table 9. Numerical parameters of simulated coal blocks (compiled from Vishal et al. 2012, 2013a, 2018).

\begin{tabular}{|c|c|c|c|c|c|c|c|c|c|}
\hline \multirow[t]{2}{*}{ Reference } & \multirow[t]{2}{*}{$\begin{array}{l}\text { Coal type } \\
\& \text { location }\end{array}$} & \multicolumn{3}{|c|}{$\begin{array}{l}\text { Coal block dimensions } \\
(\mathrm{m})\end{array}$} & \multirow[t]{2}{*}{$\begin{array}{l}\text { Depth } \\
(\mathrm{m})\end{array}$} & \multicolumn{2}{|c|}{$\begin{array}{l}\mathrm{CO} 2 \text { injection } \\
\text { well }\end{array}$} & \multicolumn{2}{|c|}{$\mathrm{CH} 4$ production well } \\
\hline & & Length & breadth & height & & Number & position & Number & position \\
\hline $\begin{array}{l}\text { Vishal et } \\
\text { al. (2012) }\end{array}$ & Gondwana & 914.4 & 731.52 & 9.144 & 533.4 & & & & equidistant \\
\hline $\begin{array}{l}\text { Vishal et } \\
\text { al. (2013a) }\end{array}$ & Raniganj & 310 & 457 & 7.3 & 365.8 & 1 & central & 2 & $\begin{array}{l}\text { from the } \\
\text { central } \\
\text { well, on }\end{array}$ \\
\hline $\begin{array}{l}\text { Vishal et } \\
\text { al. (2018) }\end{array}$ & Jharia & 914.4 & 731.52 & 9.144 & 533.4 & & & & \\
\hline
\end{tabular}

Table 10. Model parameters of Vishal et al. (2012, 2013a, 2018).

\begin{tabular}{llllll}
\hline Reference & $\begin{array}{l}\text { Average } \\
\text { permeability } \\
(\mathrm{mD})\end{array}$ & $\begin{array}{l}\text { reservoir } \\
\text { temperature } \\
\left({ }^{\circ} \mathrm{C}\right)\end{array}$ & $\begin{array}{l}\text { coal } \\
\text { density } \\
(\mathrm{KG} / \mathrm{m} 3)\end{array}$ & $\begin{array}{l}\text { Well-bore } \\
\text { diameter } \\
(\mathrm{m})\end{array}$ & $\begin{array}{l}\text { initial pore } \\
\text { pressure in } \\
\text { CH4 well }(\mathrm{kPa})\end{array}$ \\
\hline $\begin{array}{l}\text { Vishal et al. } \\
(2012)\end{array}$ & N/A & N/A & N/A & N/A & N/A \\
$\begin{array}{l}\text { Vishal et al. } \\
\begin{array}{l}(2013 \mathrm{a}) \\
\text { Vishal et }\end{array}\end{array}$ & 1.8 & 38 & 1430 & 0.09 & 180 \\
al.(2018) & 2 & 40.55 & 1440 & 0.09 & 206.84 \\
\hline
\end{tabular}

\subsubsection{Simulations}

Simulations were made for 4000 days (Vishal et al. 2013a; Vishal et al. 2018) and 7300 days (Vishal et al. 2012) to study the sequestration potential for ECBMR. In the work by Vishal et al. (2012) (Fig. 10), it was observed that for the initial period of $\sim 3000$ days, a higher rate of $\mathrm{CO}_{2}$ injection is followed by a lower rate of injection of $\mathrm{CO}_{2}$ (Table 11), which keeps on decreasing further and remains constant till the end of the studied time period. The pattern was repeated in 
Vishal et al. (2018) (Fig. 11). The total $\mathrm{CO}_{2}$ injection in Vishal et al. (2018) stood at 220Mm ${ }^{3}$ at $\sim 4000$ days (Fig. 11c). Both the studies (Vishal et al. 2012; 2018) give similar results, except that the simulation period in the former is almost double than the latter. However, the value of $\mathrm{CO}_{2}$ adsorption in Vishal et al. (2012) at 3650 days is $\sim 135 \mathrm{Mm}^{3}$, which is more than that for 4000 days in Vishal et al. (2018).

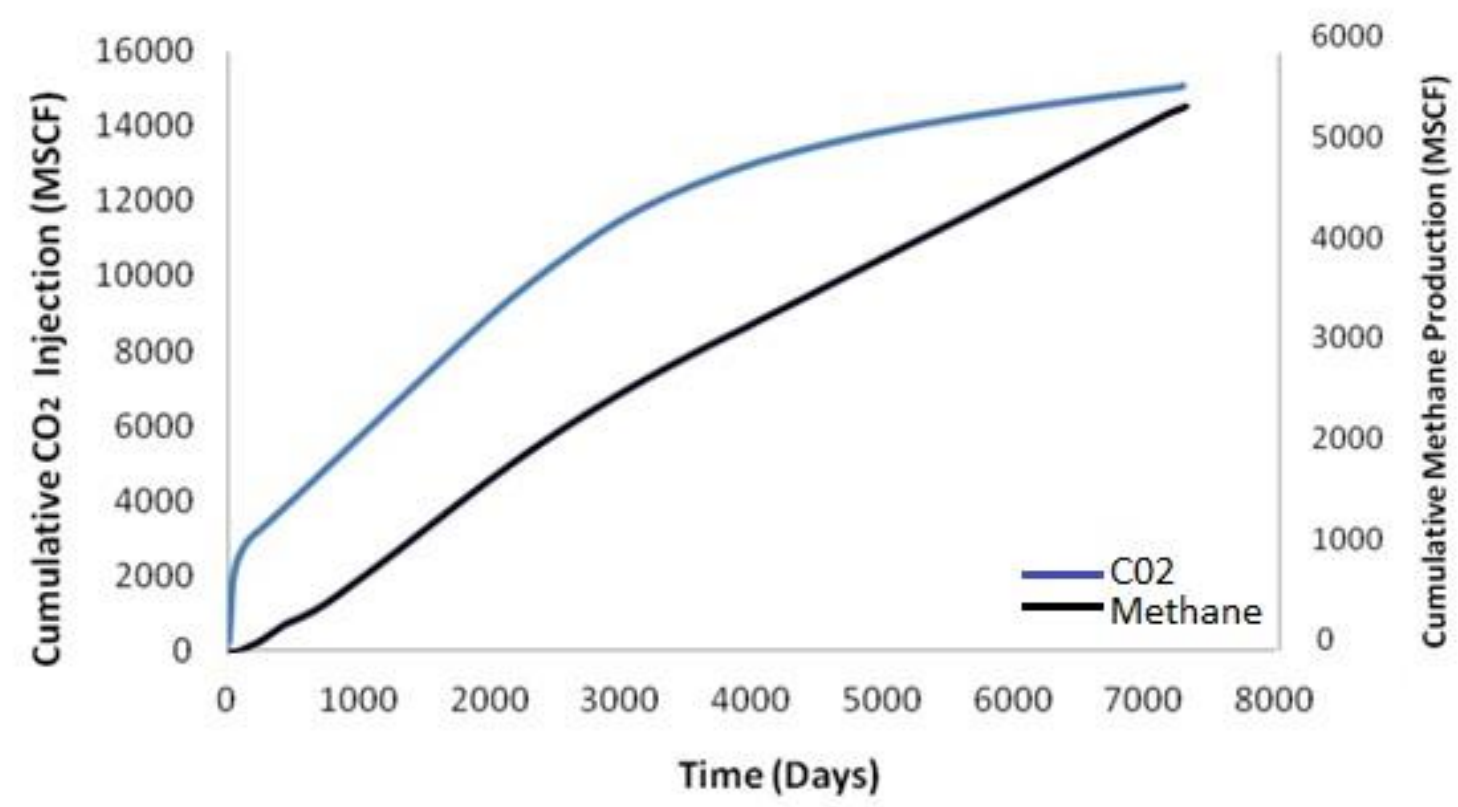

Fig 10. $\mathrm{CO}_{2}$ injection over the simulation period and $C B M$ production during the same period. Modified from fig. 2 \& 3 of Vishal et al. (2012). 

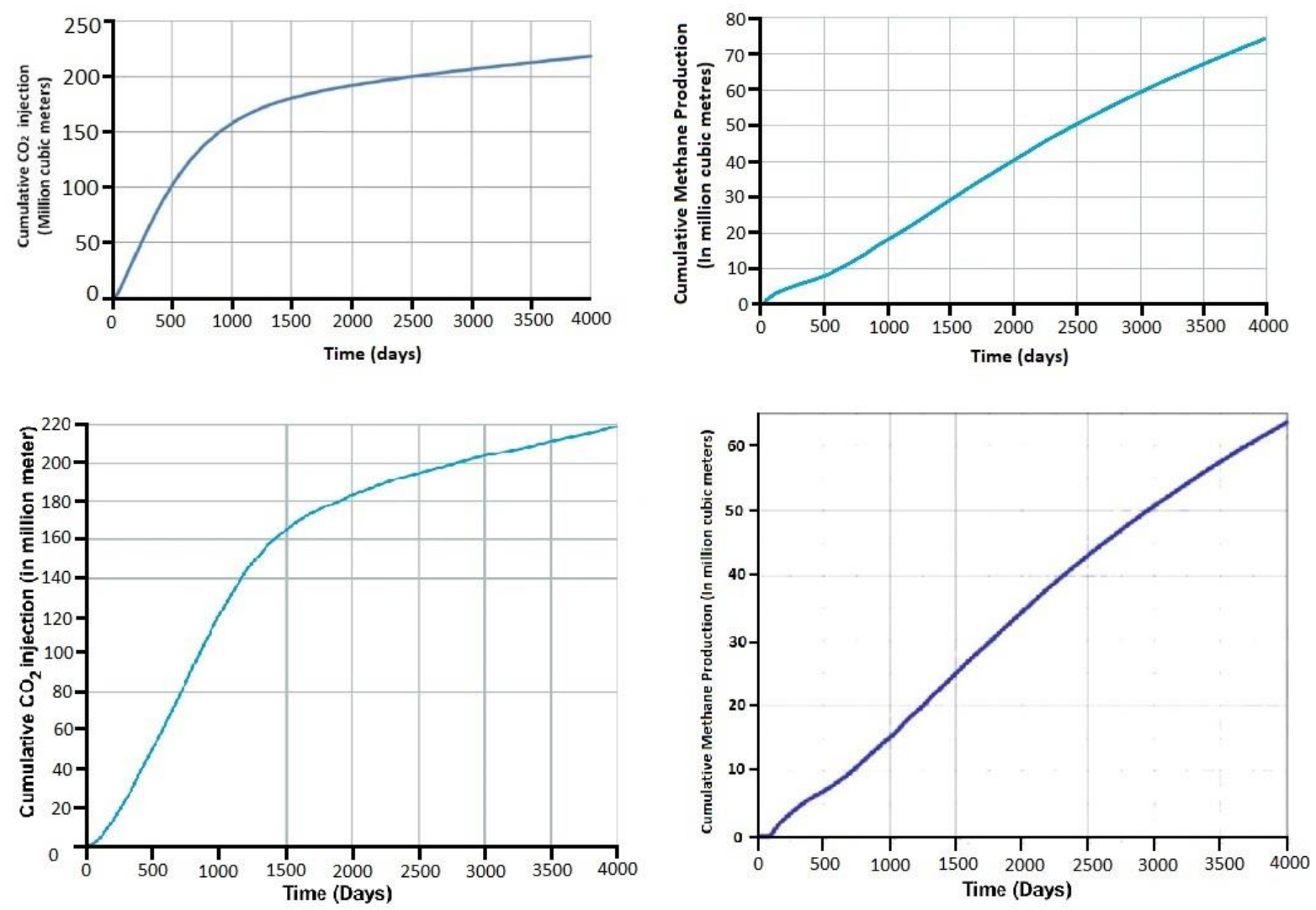

Fig 11. From left to right- $a$. CO2 injection over the simulation period. $\boldsymbol{b}$ CBM production during the same period (Modified from fig. 2 \& 3 of Vishal et al. 2013). c. $\mathrm{CO}_{2}$ injection over the simulation period; Fig 11d CBM production during the same period (Modified from fig. 7 \& 10 of Vishal et al.2018).

Table 11. $\mathrm{CO}_{2}$ adsorption (cumulative and absolute) at different stages of the simulation period (compiled and modified from Vishal et al. 2012).

\begin{tabular}{llll}
\hline $\begin{array}{l}\text { Cumulative } \\
\text { Time } \\
\text { (days) }\end{array}$ & Absolute time (days) & $\begin{array}{l}\text { Cumulative } \mathbf{C O}_{\mathbf{2}} \\
\text { adsorbed }\left(\mathbf{M m}^{\mathbf{3}}\right)\end{array}$ & $\begin{array}{l}\text { Absolute } \mathbf{C O}_{2} \text { adsorbed } \\
\left(\mathbf{M m}^{\mathbf{3}}\right)\end{array}$ \\
\hline 365 & & 99.1 & \\
1825 & 1460 & 237.86 & 138.76 \\
3650 & 1825 & 353.96 & 116.1 \\
5475 & 1825 & 399.26 & 45.3 \\
7300 & 1825 & 427.58 & 28.32 \\
\hline
\end{tabular}


Table 12. $\mathrm{CO}_{2}$ adsorption (cumulative and absolute) at different stages of the simulation period (compiled and modified from Vishal et al. 2013a).

\begin{tabular}{llll}
$\begin{array}{l}\text { Cumulative } \\
\text { Time (days) }\end{array}$ & Absolute time (days) & $\begin{array}{l}\text { Cumulative } \mathbf{C O}_{2} \\
\text { adsorbed }\left(\mathbf{M m}^{\mathbf{3}}\right)\end{array}$ & $\begin{array}{l}\text { Absolute } \mathbf{C O} \text { adsorbed } \\
\left(\mathbf{M m}^{\mathbf{3}}\right)\end{array}$ \\
\hline 100 & & 16.26 & \\
500 & 400 & 101 & 84.74 \\
1000 & 500 & 157.75 & 56.75 \\
2500 & 1500 & 200 & 42.25 \\
4000 & 1500 & 218.47 & 18.47 \\
\hline
\end{tabular}

The adsorption of $\mathrm{CO}_{2}$ leads to the release of the coal-bed methane (Figs. 10, 11b, 11d), which was another conjecture of the simulations. The onset of $\mathrm{CH}_{4}$ production is marked by the initial release of water contained within the coal block. The simulated $\mathrm{CH}_{4}$ production stood at 141 , 74.22 and 56.63 $\mathrm{Mm}^{3}$ in Vishal et al. (2012), Vishal et al. (2013a) and Vishal et al. (2018), respectively.

\subsection{Carbon sequestration in deep saline aquifers: A case study from the Ganga basin}

Indian deep saline aquifers hold the highest potential for carbon sequestration owing to their geology that has stored and restricted the flow of brackish water for a geologically long period.

Major states containing saline aquifers occur both within and outside Ganga basin, e.g., in Uttar Pradesh, Gujarat, Rajasthan, Punjab, Andhra Pradesh, Tamil Nadu and Karnataka (Bhandari 2014; CGWB 2020). Major $\mathrm{CO}_{2}$ emitting sources are also located in the nearby areas (Section 4.2.2). On the other hand, the water being brackish holds little importance for social or economic uses (Kumar 2014). Thus deep-saline aquifers can be of great potential for carbon sequestration 
in India (Chadha 2016). This can also counterbalance the carbon footprint of groundwater irrigation in India that stands between 45.3 MT and 62.3 MT (Rajan et al. 2020).

The saline aquifers of Uttar Pradesh (Fig. 12) hold the most potential for storage. This is because the depths of these aquifers are $1100 \mathrm{mbgl}$. This satisfies a preliminary criterion in $\mathrm{CO}_{2}$ storage, that it should take place at depths exceeding $800 \mathrm{~m}$. (detail in Section 2.4.3b2). The entire Ganga basin is overlain by fertile silt that is at places are $>5000 \mathrm{~m}$ deep. This causes this region to be one of the most agriculturally productive regions of the country. Since the silt depositions run to a significant depth, deep vertical electrical sounding (VES) surveys were carried out at 12 identified locations reaching $>750 \mathrm{~m}$ depth. Below such a depth, $\mathrm{CO}_{2}$ exists in a super-critical phase (Fig. 13) (Chadha 2016). 


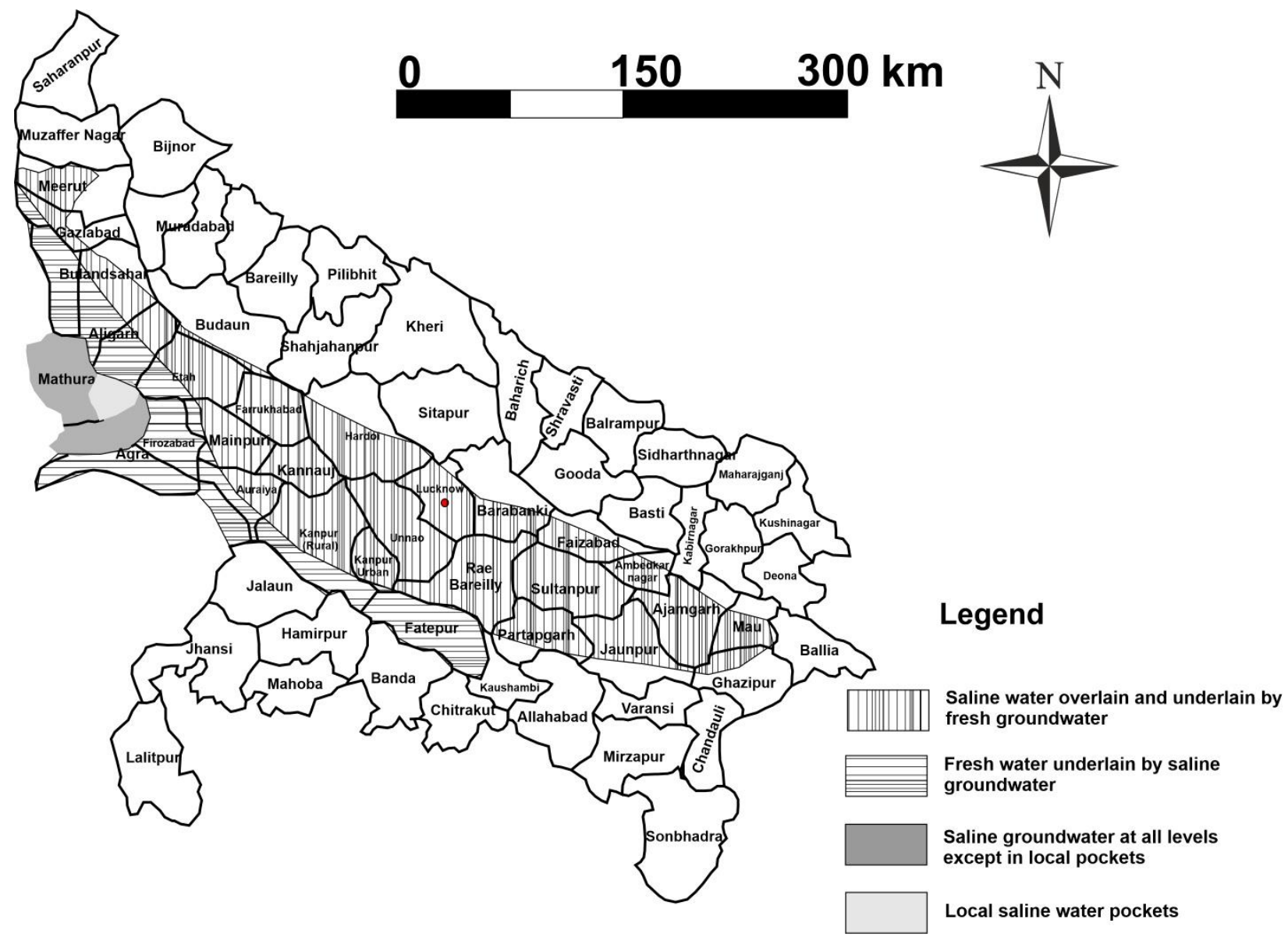

Fig 12. The district wise groundwater map of Uttar Pradesh showing major pockets of saline aquifers. Reproduced from fig. 2.5 of Chadha (2016). 


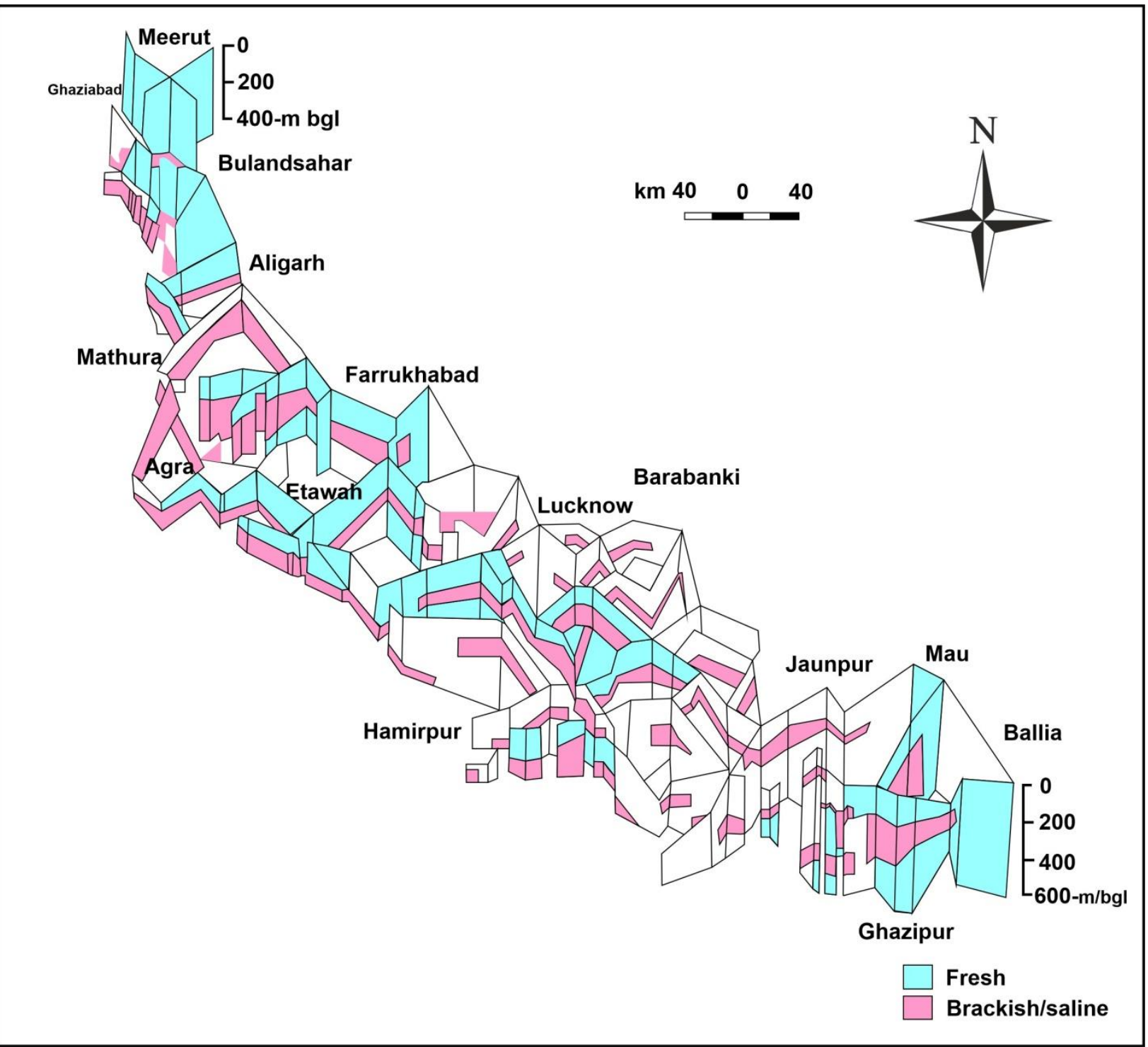

Fig 13. Groundwater salinity report of 12 locations. Reproduced from fig. 2.6 from Chadha (2016).

Chadha (2016) considered that to sequester $\mathrm{CO}_{2}$ in the saline aquifers, displacement of water to accommodate the $\mathrm{CO}_{2}$ is considered. Eqn 4 was used to approximate the amount of displaced water.

$\mathrm{F}_{\mathrm{f}}=\mathrm{VSA} \times \%$ of $\mathrm{F}_{\mathrm{f}}$ (eqn 4) 
Here $F_{f}$ : fluid faction, VSA: volume of the saline aquifer.

Based on the above calculation, it was found out that an aquifer area of $\sim 15 \mathrm{~km}^{2}$ could be saturated with $\mathrm{CO}_{2}$, the $\mathrm{CO}_{2}$ sequestration potential of the studied area is $48.3 \mathrm{MT}$ with a storage efficiency of $2 \%$. This value is close to Thibeau and Mucha's (2011) efficiency value of $1.4 \%$ from the Utsira Formation (Sleipner). However, the magnitude can vary from less than $1 \%$ to even more than $10 \%$ (Bachu, 2015) on a global-scale depending on the geological characteristics of the aquifer; injection rate, duration and strategy of $\mathrm{CO}_{2}$ and the characteristics (permeability and capillary entry pressure) of the confining aquitards.

\subsection{Sequestration potential of greenstone belts of Dharwar: Kolar \& Chitradurga}

\section{(Karnataka state)}

The greenstone belts of the Dharwar craton contain abundant alkaline silicate, which react with $\mathrm{CO}_{2}$ to form their respective carbonates thus safely sequestering the carbon. Mani et al. (2008) studied the sequestration potential of two greenstone belts in Chitradurga and Kolar (Fig. 14). The mean length and thickness of the Chitradurga belt are $450 \mathrm{~km}$ and $10 \mathrm{~km}$, while the mean length and width of the Kolar belt are 80 and $6 \mathrm{~km}$, respectively. An empirical approach was adopted. The weight percentage of $\mathrm{MgO}$ in 1 tonne of serpentine is 35-49\% (Goff and Lackner 1998), which sequesters $~ 1.5$ tonnes of $\mathrm{CO}_{2}$. Thus, $\sim 1$ tonne of $\mathrm{MgO}$ would sequester 1 tonne of $\mathrm{CO}_{2}$. In order to ascertain an approximate value eqn 5 was used:

$\mathrm{T}=1 * \mathrm{p} * \mathrm{a} * \mathrm{t} * \mathrm{~d} *(1-\phi)$

Here T: amount of $\mathrm{CO}_{2}$ sequestered, $\mathrm{p}: \%$ of $\mathrm{MgO}$ in the ultramafic, a: area (effective area is assumed as $20 \%$ up to $1 \mathrm{~km}$ depth). 
Only ultramafic komatiites have been included in the analysis for their high $\mathrm{MgO}$ content, $\mathrm{t}=$ thickness (taken as $1 \mathrm{~km}), \mathrm{d}=$ mean density of the ultramafic, and $\phi=$ mean porosity $(2 \%)$. The calculation estimated a sequestration potential of 2.94 MT for the Kolar belt and 4.7 MT in the Chitradurga belt.

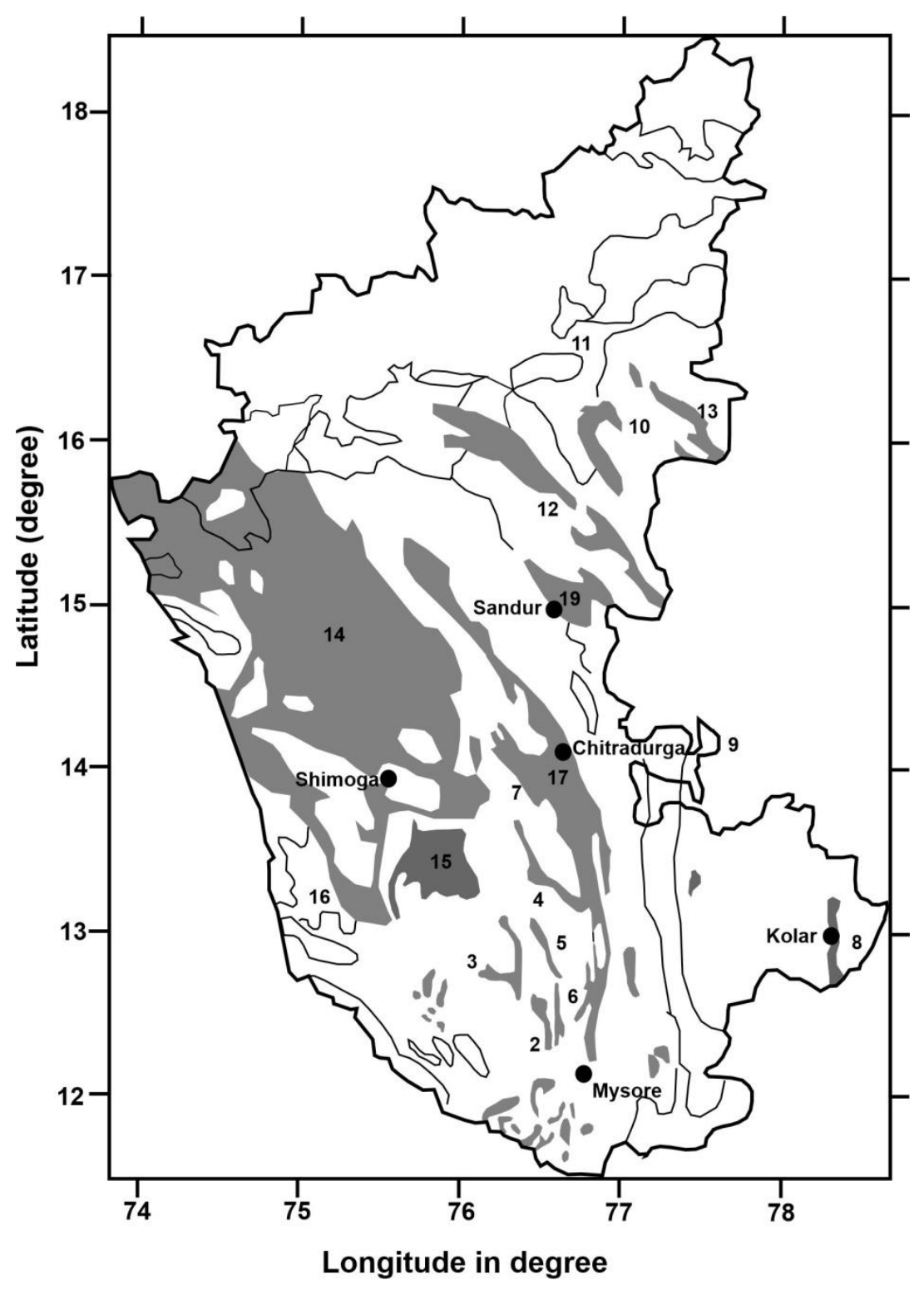

Fig 14. Greenstone belts of Karnataka showing Chitradurga (17) and Kolar (8) (reproduced from fig. 2 of Mani et al. 2008). 


\subsection{Carbon sequestration using Eastern Cottonwood tree (Poplar): A case study from the Nainital district (Uttarakhand)}

Biotic sequestration (oceanic and terrestrial) holds significant potential (Section 2.4.2b). Within terrestrial biotic sequestration, the niche of agroforestry sequestration has been recognised by the Kyoto Protocol as a method with multiple benefits apart from carbon sequestration. These include supplemental income through wood selling, cropland protection, supporting pollination etc. (Abbas et al. 2017; Gupta et al. 2017). Afforestation is also included under the CDM by Kyoto Protocol (Gera 2012). For this purpose, a case study of biotic sequestration has been included.

Gera (2012) conducted detailed modelling to ascertain the sequestration potential of Poplar trees, using PROject based COmprehensive Mitigation Assessment Process (PRO-COMAP), a spreadsheet-based model that has been designed for these types of studies. Similar studies using this model have also been conducted (Rootzén et al. 2010; Wani et al. 2012; Malhotra 2017).

Gera (2012) carried out the study in three villages Kyaribandobasti, Kanchanpur Choi, and Nandpur (Nainital district, Uttarakhand). The trees are planted in two ways. In block plantation, 500 trees are planted with five trees planted every $4 \mathrm{~m}$ and in row and bund plantation, each tree is planted $2 \mathrm{~m}$ apart. The field data collected from plantations were Above Ground Biomass (AGB), Soil Organic Carbon (SOC), Below Ground Biomass (BGB) and Woody litter. The AGB and BGB for PRO-COMAP were recorded quadrat-wise, on three different poplar age groups. A quadrat is a quadrilateral structure used in biotic samplings, such as species of animals or plants 
(Gleason 1920). In block plantation, a quadrat of size $25 \mathrm{~m} * 20 \mathrm{~m}$ was considered for the data collection. In bund and row plantations, the area was divided into strips; $10 \mathrm{~m} * 125 \mathrm{~m}$ in block plantations and three random quadrats/strip (signifying three age groups) were considered for the data collection. The mean annual increment (increase in average tree height) was calculated using the volume formula detailed in Dhanda and Verma (2001). The biomass and wood density were calculated using the biomass expansion factor (1.1) and the wood density factor (0.35). The biomass and wood density were used to calculate the AGB. The AGB was multiplied by 0.27 to obtain the Below Ground Biomass (BGB) (IPCC 2003). SOC was measured at previously selected locations, at depths of 15,30 and $45 \mathrm{~cm}$. Woody litter data is not mentioned in the study. However, SOC and woody litter have negligible impacts on the model.

The model was rendered with the collected data for 30 years. Two scenarios were modelled: with the wood product and without the wood product. In the former, trees would be cut every 6 years (average maturing period of the tree) and in the latter, the tree would be left for 30 years. In block plantation, the sequestration values were $1.33 \mathrm{t} \mathrm{C} \mathrm{h}^{-1} \mathrm{yr}^{-1}$ and $2.41 \mathrm{t} \mathrm{C} \mathrm{h}^{-1} \mathrm{yr}^{-1}$ for 'without wood' and 'with wood' simulations. In bund/row plantations, the sequestration values were 1.05 $\mathrm{t} \mathrm{C} \mathrm{h}^{-1} \mathrm{yr}^{-1}$ and $1.80 \mathrm{t} \mathrm{C} \mathrm{h}^{-1} \mathrm{yr}^{-1}$ for without wood and with wood, respectively.

\section{Prospects}

India's emission projection stands at 5.3 BT by 2030 (Section 3.3). Such figures cannot be thwarted without mainstream CCUS infrastructure retrofitted in the hard-to-abate industries such as cement, iron and steel and thermal power. The infrastructure of these industries serves as the 
backbone of the Indian economy and cannot be replaced easily. This is highly pertinent to thermal power plants. They drive the energy production in India and given that energy access and security is still a big issue at hand, CCS can make the thermal energy 'green', while efforts are pursued to transition to cleaner energy sources (Sharma 2019).

India is taking substantial leaps in the field of renewable energy. MoPGOI (2021) reported the total installed capacity of electricity at $382.73 \mathrm{GW}$ as of $30^{\text {th }}$ April 2021 . Out of this $95, \mathrm{GW}$ ( $20 \%$ ) is renewable. The Government aims to increase this to $175 \mathrm{GW}$ by 2022 (IEA 2021). This would severely cut the dependence on thermal power plants and hence curb emissions. The Indian private company Reliance Industries has included CCS in its net-zero commitments.

Curbing new emissions and sequestering $\mathrm{CO}_{2}$ requires a huge expenditure. There has not been a detailed analysis of CCS cost in India except a study concerning thermal power plants (Section 4.2). This becomes more pressing in India, given its multidimensional developmental needs. A nodal organization comprising of representatives from the Maharatna and Navratna companies can be set up which can supervise the CCUS activities in India. Besides Government funds, the major energy conglomerates such as NTPC, ONGC and CIL etc. should work towards allocating funds for CCUS projects (Ranjan et al. 2018).

CCS infrastructure is highly cost-intensive with the only United States of America somewhat succeeding in creating a CCS infrastructure (SG and TERI 2021). There are also some examples in Europe, the most well-known being Sleipner (Section 2.4.3b6). 
CDM can substantially tackle the economic issue of CCS in India. Clean Development Mechanism (CDM) is an important issue agreed upon in the Kyoto protocol, in recognition of the United Nations Framework Convention on Climate Change (UNFCCC) (Kalbende 2015). Despite several criticisms (De Coninck 2008; reviewed in Shackley and Verma 2008; Shirmohammadi et al. 2020), CCS got included under the CDM during negotiations in the Conference of Parties (COP) 17 of United Nations Framework Convention on Climate Change (UNFCCC), held in Durban, South Africa (CCJ 2012; UNFCCC 2011).

\subsection{What is a Clean Development Mechanism?}

The CDM is an important clause that allows a symbiotic relationship between the developed and the developing countries. The mechanism allows the developed countries to set up emission reduction projects and undertakings in the developing countries. This allows the developed countries to procure Certified Emission Reduction (CER) credits to their name. These credits

allow them to reach their emission reduction targets. This mechanism satisfies the twin aim of both the developed and the developing countries involving an interchange of skill, knowledge and technology (Zomer et al. 2008; Lema and Lema 2013).

\subsection{CCS-CDM}


The CDM consists of a project cycle that is to be satisfied before its execution. The cycle consists of the steps outlined below. These have been mainly compiled from Kalbende (2015) with cross-verifications from Thorne and La Rovere (1999), (UNEP 2005) and (UNFCCC 2011):

- CDM project design

- National approval

- Validation \& registration

- Project financing

- Implementation and monitoring

- Verification and issue of CER units

\subsubsection{CDM project design}

The mechanism commences with a specific project blueprint that would set the base of the project. This design should be both ambitious and conceivable. Since the present work deals with CCS, the CDM project design in this scenario should set forth baseline emission data according to which the designated project would proceed. This baseline emission date will be extracted depending on the actual emission of the source, technological advancement and human resource potential.

In the Indian context, the project design and development include several other factors. Carbon capture and storage procedures require understanding and preparation for all possible outcomes. Since the storage of $\mathrm{CO}_{2}$ in geological repositories at $>800 \mathrm{~m}$ depths (Riley 2010) is of primary concern here, accidental leakages needs be accounted for. A subsidiary plan accounting for the 
accidental or unfortunate leakages needs to be worked on. The financial fluctuation between the buyers and sellers are also to be looked after in the plan itself. This is because the prices of the CER units are subject to volatility and thus the buyer and the seller needs to negotiate and agree on all the common acceptable terms to both parties.

\subsubsection{National approval}

After agreement on the negotiated terms by both parties, the CDM project design requires the approval of the national authority. All the countries involved in the project must designate an authoritative body to preside over the viability of the project, its impact and outcomes across all levels. This authoritative body becomes the point of contact between the countries involved. The body must ensure that the project design is congruent with the international laws and conventions. These are:

- The UNCLOS agreement (1982)

- The London convention (1972) on the prevention of marine pollution due to dumping of wastes and other matter

- The OSPAR convention (1992) for the Protection of Marine Environment of The North Atlantic.

- The Kyoto protocol (1992) 


\subsubsection{Validation \& registration}

The national approval of the project is followed by the preparation of an official project document that contains detailed information on the following points.

- General description

- Baseline analysis

- Project timeline and credit period

- Monitoring plan

- Greenhouse gas emission values by sources

- Environmental impact assessment (EIA) reports

- Comment of the involved stakeholders

After the submission of the detailed document, the project is validated by the designated authority. Then the project is passed on to the executive committee that comprises 10 members as per the UNO's regulations, for the project registration.

\subsubsection{Project financing:}

The next step is to secure adequate funding for the CDM project, however, in any circumstances public funding meant for the development expenditure and in no way the CDM project finances should impede any ongoing development process.

\subsubsection{Implementation and monitoring:}

After the financing is procured, the project is set forth for implementation. A CCS-CDM project takes a comparatively longer implementation period due to the scale of the projects. 


\subsubsection{Verification and issue of CER units:}

The designated body would then verify the results of CDM projects. The body needs to ensure that the project has been executed without deviating from the issue's guidelines and regulations. After the designated body is thoroughly convinced of the results of CDM projects, they will proceed with the issuance of CER units.

The CER certification would recognise the success of the CDM project. This CER unit can be used by developed countries to lower their $\mathrm{CO}_{2}$ reduction targets.

\subsection{CCS-CDM in India}

Currently, there are no CCS-CDM projects operational in India. India has the status of a developing economy. Meeting the power needs and alleviating the widespread poverty is the major concern for the Government. Tackling the energy crisis economically seems to be the top priority of the Government at this moment and deploying the CCS project would only thwart the economic aspect of tackling the energy crisis. In 2006, two CCS-CDM proposals were submitted to the Government in India, however, none of them materialised. The GOI recognises CCS as a technology of the future in the Indian context. The year 2030 can be envisaged as the year when the CCS projects might begin taking effect. Until then R\&D is the only thing that the Government is presumably concerned. However, the Government still is lenient upon CCS-CDM projects if the interested international party is willing to cover all costs (Shackley and Verma 2008; Viebahn et al. 2014). 


\subsection{Other methods and existing schemes:}

Besides global methods such as CCS-CDM, an explicit method such as carbon pricing or carbon tax, where a tax is imposed on the amount of emissions, can prove beneficial. Currently, according to IMF, this tax should be close to USD 75 per tonne by 2030 to achieve the Paris goals. However, no such explicit mechanism exists in India. Certain implicit methods seek to serve the same purpose (Chandra 2021).

- Coal cess - This was implemented in 2010. It introduced excise duty on coal. Its pricing reached INR 400 per tonne in 2016. The excise collected from it was allotted to the National Clean Energy Fund (NCEF) that finances clean energy research and initiatives. This scheme was, however, not implemented properly. Between 2010-11 and 2017-18, only $34 \%$ of the collected duty was allotted to NCEF, further out of which only $50 \%$ was utilised. In 2017, however, this scheme was abolished (Shakti and EY 2018; Chandra 2021).

- Perform, achieve or Trade Scheme (PAT) - The first cycle of PAT scheme was launched in 2012-17, coordinated by Indian Energy Exchange (IEE). Its sets energy reduction targets (ERTs) for high emission industrial sources. The ERTs achievement is acknowledged with Energy Saving Certificates (ESCs). The ESC is equal to 1 tonne of oil. Inability to achieve the ERTs requires the companies to buy ESCs. The combined reduction from the first and second cycles $(2016-17,2018-19)$ was 92 tonnes of $\mathrm{CO}_{2}$. The fourth PAT cycle commenced in 2020 (Shrimali 2018; Chandra 2021).

- Renewable Purchase Obligation (RPOs): Similar to PAT, RPOs set a target for Indian states to produce a certain amount of energy from renewable sources to meet their 
requirements. The states that do achieve the target are awarded Renewable energy certificates (RECs). The RPOs are tradable at energy exchanges. Although ambitious, this scheme like the coal cess has not achieved much. In 2019-20, only four states met their RPOs (Mishra 2020; Chandra 2021).

- Internal Carbon Pricing (ICP): ICP is a voluntary scheme where private organisations set a price on their carbon emissions and use the fund to transition to low emissions technologies. This is done in three ways:

i) Internal or private carbon fee where the revenue generated is funnelled towards low emission alternatives

ii) Implicit price where company measures the amount to meet government emission reduction targets. This enables them to track the revenue, invest in their low emission targets and minimize their carbon footprint

iii) The Shadow price is where a company sets a theoretical carbon price and use that as an index to fund their low emission incentives.

As of 2019, 22 companies have implemented ICP, out of which four companies have to implement implicit price, three have implemented private or internal price, nine have implemented shadow price, 1 has a carbon offset (where emission made from one source is offset by reducing from another source) price, three have a combination of implicit and shadow and one has a combination of implicit and private or internal. This initiative has been gaining traction in the private sector (Chandra 2021; CCES 2021). 
Bhat and Mishra (2020)'s analyses show that such taxes have been quite effective in increasing the $R \& D$ in the clean energy sector. This, however, is still very ineffective in increasing the share of cleaner energy sources in the Indian energy mix, which is still dominated by fossil fuel (primarily coal). A pronounced shift in the energy production source is needed to move towards a cleaner energy mix. Increase in public-private partnership investment in renewable energy also has the ability to decrease carbon emissions in India (Kirikkaleli and Adebayo 2020).

\subsection{Latest initiatives: Accelerating CCUS technologies (ACT) (DST 2020b; GCCSI 2020)}

The most recent initiative of the Indian Government has been the ACT. ACT is an international consortium to fund and accelerate the development of CCUS technology. India has recently become a member of the ACT and joined hands with Netherlands, Denmark, Alberta province in Canada, the Nordic Region, France, Greece, Germany, Italy, Norway, Romania, Turkey, Spain, Switzerland, UK and the USA. Under this initiative, India has pledged a million Euros ( $~ 88$ million INR) to support the Indian projects.

Under the ACT, DST has invited proposals ranging from small-scale research projects to pilot sites. This proposal should be in collaboration with at least three ACT countries. Any such project should be industrially scalable.

The ACT proposal call is a two-step process:

- Call for pre-proposal (stage 1) - This was remain open up to 10-Nov-2020.

- Call for full-proposal (Stage 2) - Participants selected in stage 1 move to stage 2. This was open till 15-March-2021. 
The selected projects would start from September 2021.

\section{Conclusions}

The article extensively reviewed the current scenario and prospects of CCS in India. Such a review was much needed as we enter a new decade where climate-related action will be at the forefront. CCS will play a major role in it. Given the vastness of the topic, this article does not delve deeper into individual technologies and other subtopics.

The article provides an overarching view of CCS in the Indian context and presents a coherent picture of the current situation. Each section can be further studied for a more detailed analysis of its full potential and limitations. Several initiatives are in the R\&D stage (Section 4.1). India also possesses substantial geological repositories (Section 4.3.2) and biotic sequestration capabilities (Section 4.4). Some simulation and feasibility studies have already been carried out (Section 5) and some are underway (Section 4.1). All the case studies discussed (Section 5) are highly promising and scalable. Both the biotic and abiotic options need to be at the forefront for a holistic approach to CCS. The sequestration options in the saline aquifers and depleted hydrocarbon reserves hold more potential given that there are several operational sites in the world including India. All the projects discussed under R\&D (Section 4.1) hold significant promise, although some are still in the experimentation stage. These projects can complement each other to tackle the issue of CCS in India. 
Public-private partnership framework has the ability to play a major role in this regard. These options need to be complemented with suitable, adaptable, and scalable policy measures targeted at carbon sequestration in India. All of these need to work towards decreasing the per unit cost of carbon capture as that still accounts for the major expenditure in sequestration. Continued R\&D and focused policies are the key things to achieve this goal.

The next 10-15-year period is crucial for the development of CCS technologies in India. India would look to cover the technological gap in its power production and distribution sector, thus also enhancing the chances of successful deployment of CCS technologies to the power plants post-2030. This step would ensure India's position on global energy as well as in the carbon reduction map. 
Acknowledgements: RS worked as a self-financed summer intern with SM in 2018. SM was supported by the CPDA grant of IIT Bombay. Mohit Kumar Puniya (Survey of India, Dehradun, India) computerized several figures. RS: preparing and finalizing the ms. SM: supervision and finalizing the ms. Chief Editor Dr. Chunfei Wu and anonymous reviewers are thanked for providing several crucial comments in two rounds.

\begin{tabular}{ll} 
ABBREVIATIONS & \\
AGR & Acid Gas Removal \\
ASU & Air separation unit \\
BT & Billion Tonnes \\
C & Carbon \\
CBMR & Coal Bed Methane Recovery \\
CCS & Carbon Capture and Storage \\
CCUS & Carbon Capture, Utilisation and Storage \\
CDM & Clean Development Mechanism \\
CER & Methane \\
\hline & Carbon Emission Reduction \\
&
\end{tabular}




\begin{tabular}{|c|c|}
\hline $\mathrm{CO}$ & Carbon monoxide \\
\hline $\mathrm{CO}_{2}$ & Carbon di-oxide \\
\hline CSMCRI & Central Salt \& Marine Chemicals Research Institute \\
\hline DGH & Directorate General of Hydrocarbons \\
\hline DGMS & Directorate General of Mines Safety \\
\hline DST & Department of Science \& Technology \\
\hline ECBMR & Enhanced Coal Bed Methane Recovery \\
\hline EGR & Enhances Gas Recovery \\
\hline EOL & Essar Oil Limited \\
\hline EOR & Enhanced oil recovery \\
\hline $\mathrm{Ft}$ & feet \\
\hline GEECL & Great Eastern Energy Corporation Limited \\
\hline GOI & Government of India \\
\hline GHG & Greenhouse Gas \\
\hline $\mathrm{h}$ & hectare \\
\hline HRSG & Heat-Recovery Stream Generator \\
\hline ICTS & Indo-Can Technology Solutions \\
\hline IGCC & Integrated Gasification Combined Cycle \\
\hline
\end{tabular}




$\begin{array}{ll}\text { IIT-B } & \text { Indian Institute of Technology-Bombay } \\ \text { IIT-KGP } & \text { Indian Institute of Technology- Kharagpur } \\ \text { INDC } & \text { Intended Nationally Determined Contribution } \\ \text { IRCC } & \text { Integrated Reformed Combined Cycle } \\ \text { JNCASR } & \text { Jawaharlal Nehru Centre for Advanced Scientific Research } \\ \text { Km } & \text { Kilometre } \\ \text { M } & \text { Metre } \\ \text { MEA } & \text { Monoethanaloamine } \\ \text { Mt } & \text { metric tonne } \\ \text { NTPC } & \text { Nillion Tonnes } \\ \text { MT } & \text { National Thermal Power Corporation } \\ \text { NGRI } & \text { Million years } \\ \text { Mya } & \text { National Aluminium Corporation } \\ \text { NALCO } & \text { National Environmental Engineering Institute } \\ \text { NEER } & \\ \text { National Geophysical Research Institute }\end{array}$




$\begin{array}{ll}\text { PCC } & \text { Post combustion capture } \\ \text { Pg } & \text { Petagram }\left(1 \mathrm{Pg}=10^{15} \mathrm{~g}\right) \\ \text { PTFE } & \text { parts per million } \\ \text { SOM } & \text { Polytetrafluorethylene } \\ \text { ICOSAR } & \text { Soil Organic Matter } \\ \text { t }- \text { tonne } & \text { Indian } \mathrm{CO}_{2} \text { Sequestration Applied Research } \\ \text { UNCLOS } & \text { United Nations Convention on the Law of the Sea } \\ \text { UNFCCC } & \text { United Nations Framework Convention on Climate Change } \\ \text { WGS } & \text { Water Gas Shift } \\ \text { yr } & \text { Year }\end{array}$




\section{References}

Abbas F, Hammad HM, Fahad S, Cerdà A, Rizwan M, Farhad W, Ehsan S, Bakhat HF (2017). Agroforestry: a sustainable environmental practice for carbon sequestration under the climate change scenarios—a review. Environ Sci Pollut Res 24: 11177-11191.

https://doi.org/10.1007/s11356-017-8687-0

Anandarajah G, Gambhir A (2014) India's CO2 emission pathways to 2050: what role can renewables play? Applied energy131: 79-86. Doi: $\underline{\text { 10.1016/j.apenergy.2014.06.026 }}$

AON (2019) Weather, Climate \& Catastrophe Insight. AON

Ashour (2018) How a coke plant works. Clean air journal. https://gaspgroup.org/how-a-cokeplant

works/\#: :text=Coal\%20is\%20converted $\% 20$ into $\% 20$ coke,fuel $\% 20 \mathrm{in} \% 20 \mathrm{a} \% 20 \mathrm{blast} \% 20$ furnace .$\&$ text $=$ This $\% 20$ process $\% 20$ is $\% 20$ referred $\% 20$ to,into $\% 2025 \% 20$ tons $\% 20$ of $\% 20$ coke Accessed 05 September 2021

Arehart J H, Hart J, Pomponi F, D'Amico B (2021) Carbon sequestration and storage in the built environment. Sustainable Production and Consumption 27: 1047- 1063. https://doi.org/10.1016/j.spc.2021.02.028

Azar C\& Rodhe H (1997) Targets for stabilization of atmospheric $\mathrm{CO}_{2}$. Science 276:1818-1819. 
Bachu S (2015) Review of $\mathrm{CO}_{2}$ storage efficiency in deep saline aquifers. International Journal of Greenhouse Gas Control 40: 188-202.

Bagchi A K (2020) Some Public Health Issues in India. In: Saleth R M, Galab S, Revathi E (Eds.) Issues and Challenges of Inclusive Development. Springer, Singapore, pp 175-183.ISBN 978-981-15-2228-4.

Benson S, Orr F (2008) Carbon Dioxide Capture and Storage. MRS Bulletin33(4): 303-305. doi: $10.1557 / \mathrm{mrs} 2008.63$

Bergstorm J C, Ty D (2017) Economics of Carbon capture and storage. In Yun Y (Ed) Recent advances in Carbon Capture and Storage. InTech, Croatia, pp 241 - 253. ISBN 978-953-51$6697-9$

Bhandari A, Sarin N, Chadha DK. (2008). Saline aquifers: Attractive and viable options for carbon dioxide storage- Indian perspective. In: Goel M, Kuma, Charan SN (Eds) Carbon Capture and Storage: R\&D Technologies for Sustainable Energy Future. Narosa Publishing House. New Delhi. ISBN: 978-81-7319-944-8. pp. 105-110.

Bhandari A K (2014) Geological Sequestration of CO2 in Saline Aquifers-an Indian Perspective. In: Goes M, Sudhakar M, Shahi RV (Eds) Carbon Capture, Storage and, Utilization: A possible climate change solution for energy industry. TERI Press. Delhi. pp. 107122. ISBN 780367179083. 
Bhat A A, Mishra P P (2020) Evaluating the performance of carbon tax on green technology: evidence from India. Environmental Science and Pollution Research 27, 2226-2237.

Bhatt J R, \& Kathiresan K (2012). Valuation, carbon sequestration potential and restoration of mangrove ecosystems in India. Sharing Lessons on Mangrove Restoration 19.

Bhattacharyya P S (2018) Sustainability of Coal as a Source of Energy in India. In: Dey S, Assadi M, Bandyopadhyay S, Mukherjee DA (Eds) Sustainable Energy Technology and Policies: A Transformational Journey Volume 1. pp. 255-264. Springer, Singapore. ISBN 978981-10-7188-1.

Bhattacharyya R, Ghosh BN, Mishra PK, Mandal B, Rao CS, Sarkar D, Das K, Anil KS, Lalitha M, Hati KM, Franzluebbers AJ. (2015) Soil degradation in India: Challenges and potential solutions. Sustainability 7(4): 3528-3570.

Bhandari D, Shrimali G (2018) The perform, achieve and trade scheme in India: An effectiveness analysis. Renewable and Sustainable Energy Reviews 81(1) :1286-1295. https://doi.org/10.1016/j.rser.2017.05.074

Bhui UK (2021). Hydrocarbon Cycle for Sustainable Future: Clean Energy and Green Environment of the Earth. In: Bhui U K (Ed) Macromolecular Characterization of Hydrocarbons for Sustainable Future: Applications to Hydrocarbon Value Chain. Springer, Singapore, pp 3-18. ISBN 978-981-33-6133-1 
Blackburn T J, Olsen P E, Bowring S A et al (2013) Zircon U-Pb geochronology links the endTriassic extinction with the Central Atlantic Magmatic Province. Science 340(6135): 941945.DOI: $10.1126 /$ science. 1234204

Bonto M, Welch MJ, Luthje M, Anderson SI, Veshareh MJ, Amour F, Afrough A, Mokhtari R, Hajiabadi MR, Alizadeh MR, Larsen CN, Nick HM (2021) Challeges and enablers for largescale CO2 storage in chalk formations. Earth-Science Reviews 222: 103826.

Bose H,Satyanarayana T (2021) Mitigating Global Warming Through Carbonic AnhydraseMediated Carbon Sequestration. In: Goel M, Satyanarayana T, Sudhakar M, Agrawal DP. (Eds.) Climate Change and green chemistry of CO2 sequestration. Springer, Singapore, pp 197-229. ISBN: 978-981-16-0028-9.

BP (2020) Statistical Review of World Energy 2020. BP p.l.c

Bradshaw J, Bachu S, Bonijoly D, Burruss R, Holloway S, Christensen N P, \&MathiassenO M (2007) CO2 storage capacity estimation: Issues and development of standards. International Journal of Greenhouse Gas Control 1(1): 62-68. doi:10.1016/s1750-5836(07)00027-8

Brown C J, Poiencot B K, Hudyma N, Albright B, \& Esposito R A (2013) An assessment of geologic sequestration potential in the panhandle of Florida USA. Environmental Earth Sciences 71(2): 793-806. doi:10.1007/s12665-013-2481-1 
Buckingham J, Reina TR, Duyar MS (2022) Recent advances in carbon dioxide capture for process intensification, Carbon Capture Science \& Technology. https://doi.org/10.1016/j.ccst.2022.100031

Budinis S, Krevor S, Dowell N M, Brandon N, \& Hawkes A (2018) An assessment of CCS costs, barriers, and potential. Energy Strategy Reviews 22: 61-81. doi:10.1016/j.esr.2018.08.003

Bui M et al. (2018). Carbon capture and storage (CCS): the way forward. Energy \& Environmental Science 11(5): 1062-1176. Doi 10.1039/c7ee02342a

Carbon capture journal (2012) http://www.carboncapturejournal.com/news/ccs-included-underthe-cdm-at cop17/3063.aspxAccessed 23 October 2020.

Carrera G V, Branco L C, da Ponte M N (2017) Bio-inspired Systems for Carbon Dioxide Capture, Sequestration and Utilization. In: Yun Y (Ed) Recent Advances in Carbon Capture and Storage, InTech Publishers, pp 117-138. ISBN 978-953-51-3006-2.

Celia M, Bachu S (2003). Geological Sequestration of CO2 Is Leakage Unavoidable and Acceptable? Greenhouse Gas Control Technologies - 6th International Conference, 477482. doi:10.1016/b978-008044276-1/50076-3

Central Ground Water Board (2020) ANNUAL REPORT 2018-19. Faridabad: Ministry of Jal Shakti. 
Centre for Climate and Energy solutions (2021) Internal Carbon Pricing. CCES

https://www.c2es.org/content/internal-carbon

pricing/\#: : :text=An\%20internal\%20price\%20places\%20a,to\%20a\%20low\%2Dcarbon\%20econo

my. (Accessed 06-Sept-2021)

Chadha D K (2016) Gangetic Alluvial Plains: Uniqueness of the Aquifer System for Food

Security and for Carbon Dioxide Sequestration. In: Thangarajan M, Singh VP (Eds)

Groundwater Assessment, Modelling, and Management.CRC Press, Boca Raton, pp39-54.ISBN-

13:978-1-4987-4284-9.

Chakroborty A B (2008). Carbon capture and storage: ONGC's perspective and plans. Workshop on CCS.

Chatterjee R, Paul S (2016) Coal bed methane exploration and possibility for CO2 sequestration in Jharia coalfield, India. Journal of Indian Geophysical Union 1: 37-41.

Chen X, Zhang X, Church J A, Watson C S, King M A, Monselesan D, Harig C (2017) The increasing rate of global mean sea-level rise during 1993-2014. Nature Climate Change7(7): $492-495$.

Church J A, White N J (2011) Sea-level rise from the late 19th to the early 21 st century. Surveys in Geophysics 32: 585-602. https://doi.org/10.1007/s10712-011-9119-1 
Cifuentes JM et al. (2015). Guidelines for documenting and reporting tree allometric equations. Annals of Forest Science 72: 763-768. https://doi.org/10.1007/s13595-014-0415-z

Crowley T J, Hyde W T, Peltier R. (2001) $\mathrm{CO}_{2}$ levels required for deglaciation of a “Near-Snowball” Earth. Geophysical Research Letters 28(2): 283-286. DOI:

$\underline{10.1029 / 2000 G L 011836}$

Das I, Ramkumar V， Gardas RL (2021). Thermodynamic Analysis of Ionic Liquids for CO2 Capture, Regeneration and Conversion. In: Goel M, Satyanarayana T, Sudhakar M, Agrawal DP. (Eds.) Climate Change and green chemistry of $\mathrm{CO} 2$ sequestration. Springer, Singapore, pp 123-140. ISBN: 978-981-16-0028-9.

Dayal AM, Patil DJ, Mani D (2008). Monitoring of geologically sequestrated $\mathrm{CO}_{2}$. In: Goel M, Kuma, Charan SN (Eds) Carbon Capture and Storage: R\&D Technologies for Sustainable Energy Future. Narosa Publishing House, New Delhi, pp 195-199. ISBN: 978-81-7319-944-8.

De Coninck H (2008) Trojan horse or horn of plenty? Reflections on allowing CCS in the CDM. Energy Policy 36(3): 929-936.https://doi.org/10.1016/j.enpol.2007.11.013.

Demir H, Aksu G O, Gulbalkan H C, Keskin S (2022) MOF Membranes for CO2 Capture: Past, Present and Future. Carbon Capture Science \& Technology 2: 100026. https://doi.org/10.1016/j.ccst.2021.100026 
De Silva G PD, Ranjith P G, PereraM S A (2015) Geochemical aspects of CO2 sequestration in deep saline aquifers: A review. Fuel 155: 128 143. doi:10.1016/j.fuel.2015.03.045

DebataA,Debata M, Panda D (2018) Population growth and environmental degradation in India. Research \& Reviews: Journal of Ecology 3(2): 14-22.

del Real PG, Vishal V (2016) Mineral Carbonation in Ultramafic and Basaltic Rocks. In Geologic Carbon Sequestration . Springer, Cham, pp 213-229. ISBN 978-3-319-27019-7.

Descamps C,Bouallou C, Kanniche M (2008) Efficiency of an Integrated Gasification Combined Cycle (IGCC) power plant including $\mathrm{CO}_{2}$ removal. Energy 33(6): 874881.https://doi.org/10.1016/j.energy.2007.07.013

Dieng H B, Cazenave A, Meyssignac B, Ablain M (2017) New estimate of the current rate of sea level rise from a sea level budget approach. Geophysical Research Letters 44:3744-3751.

DGMS (1967) The Coal Mines Regulations. Dhanbad, India: Directorate General of Mines Safety.

DGMS (2014). Coal Statistics - 2014. Dhanbad: Directorate General of Mines Safety.

Dhanda R S, Verma R K (2001) Timber volume and weight tables of farm-grown poplar (Populus deltoidesBartr. Ex Marsh.) in Punjab (India). Indian Forester 127(1), 115-130. 
Dhyani S K, Ram A, Newaj R, Handa AK, Dev I (2020). Agroforestry for carbon sequestration in tropical India. In Ghosh P K, Mahanta S K, Mandal D, Mandal B, Ramkrishnan S. (Eds) Carbon management in tropical and sub-tropical terrestrial systems . Springer, Singapore, pp. $313-331$.

Di Lorenzo G, Barbera P, Ruggieri G, Witton J,Pilidis P, Probert D (2013) Pre-combustion carbon-capture technologies for power generation: an engineering-economic assessment. International Journal of Energy Research 37(5): 389-402.DOI: 10.1002/er.3029

Diao Y, Zhang S, Wang Y, Li X, Cao H(2014) Short-term safety risk assessment of $\mathrm{CO}_{2}$ geological storage projects in deep saline aquifers using the Shenhua CCS Demonstration Project as a case study. Environmental Earth Sciences73(11): 7571-7586. doi:10.1007/s12665-014$3928-8$

Drage T C, Smith K M,PevidaC,Arenillas A, Snape C E (2009) Development of adsorbent technologies for post-combustion $\mathrm{CO}_{2}$ capture. Energy Procedia 1(1): 881-884. https://doi.org/10.1016/j.egypro.2009.01.117

DST(2020a). JNCASR signs MoU with incubated company for scaling up technology for reducing CO2 to methanol \& other useful chemicals. Department of Science and Technology. https://dst.gov.in/jncasr-signs-mou-incubated-company-scaling-technology-reducing-co2methanol-other-useful-chemicals(Accessed 23-Oct-2020). 
DST (2020b). DST encourages translational research on Carbon Capture, Utilisation \& Storage. https://dst.gov.in/dst-encourages-translational-research-carbon-capture-utilisation-storage (Accessed 08-July-2021)

Du Can S D L R, Khandekar A, Abhyankar N, Phadke A, Khanna N Z, Fridley D, Zhou N (2019) Modeling India's energy future using a bottom-up approach. Applied Energy238: 11081125.

Eaton BA (1975) The Equation for Geopressure Prediction from Well Logs. Fall Meet. Soc. Pet. Eng. AIME, Texas, U.S.A.

Elmabrouk S K, Bader H E, Mahmud W M (2017) An overview of power plant CCS and $\mathrm{CO}_{2}$ EOR projects. In International Conference on Industrial Engineering and Operations Management.

EmunF,GadallaM,Majozi T, Boer D(2010) Integrated gasification combined cycle (IGCC) process simulation and optimization. Computers \& Chemical Engineering 34(3): 331-338. https://doi.org/10.1016/j.compchemeng.2009.04.007

Ettehadtavakkol A (2016) Storage of $\mathrm{CO}_{2}$ in depleted/producing oil reservoirs. In Vishal V, Singh T N (Eds) Geologic Carbon Sequestration . Springer, Cham, pp185-209. ISBN 978-3$319-27019-7$. 
Europa Publications (2020). Geneva Convention on Long-Range Transboundary Air Pollution. https://publications.europa.eu/resource/cellar/5ab9bbd2-018b-43c1-99d3

3ac8f3b1c00b.0004.03/DOC_1(Accessed on 14-Sept-2021)

Faiz M M, Saghafi A, Barclay S A, Stalker L, Sherwood N R, Whitford D J (2007)Evaluating geological sequestration of $\mathrm{CO} 2$ in bituminous coals: The southern Sydney Basin, Australia as a natural analogue. International Journal of Greenhouse Gas Control 1(2): $223-$ 235. doi:10.1016/s1750-5836(07)00026-6

Farsi M, SoroushE (2020) $\mathrm{CO}_{2}$ absorption by ionic liquids and deep eutectic solvents. In: Mohammad Reza Rahimpour, Mohammad Farsi, Mohammad Amin Makarem (Eds) Advances in Carbon Capture. Woodhead Publishing, Duxford, pp 89 - 105. ISBN 9780128196571

Feron P H M, Hendriks C A(2005) $\mathrm{CO}_{2}$ capture process principles and costs. Oil \& Gas Science and Technology 60(3): 451-459.DOI: 10.2516/ogst:2005027

Figueroa J D,FoutT,PlasynskiS,Mcllvried H, Srivastava R D (2008) Advances in $\mathrm{CO}_{2}$ capture technology — the US Department of Energy's Carbon Sequestration Program. International Journal of Greenhouse Gas Control 2: 9-20. https://doi.org/10.1016/S1750-5836(07)00094-1

Finkelman R B, Wolfe A, Hendryx M S (2021) The future environmental and health impacts of coal. Energy Geoscience 2(2):99-112 
Flannigan M D, Amiro B D, Logan K A, Stocks B J, Wotton B M (2006) Forestfires and climate change in the $21^{\text {st }}$ century. Mitigation and adaptation strategies for global change 11(4): 847-859. https://doi.org/10.1007/s11027-005-9020-7

Frank C (2015) India: Potential for Even Greater Emissions Reductions. The Brookings Institution. https://www.brookings.edu/wp-content/uploads/2016/07/india-frank-1.pdf Accessed $\underline{03 \text { May } 2021}$

Ganguli S S(2017) Integrated Reservoir Studies for CO2-Enhanced Oil Recovery and Sequestration: Application to an Indian Mature Oil Field. Springer, pp 1-134. ISBN: 978-3-31955843-1.

Ganguli S S,Dimri V P,Vedanti N(2016a) Integrated Flow Simulation, Rock Physics \& Geomechanics Identifies $\mathrm{CO}_{2}$-EOR and Storage Potential at Ankleshwar, India. In 78th EAGE Conference and Exhibition.

Ganguli S. S, Vedanti N, Akervoll I, Dimri VP (2016b) Assessing the feasibility of CO2enhanced oil recovery and storage in mature oil field: A case study from Cambay basin. Journal of the Geological Society of India 88(3): 273-280. doi:10.1007/s12594-016-0490-x

Garg A, Shukla PR, Kankal, B. Mahapatra D (2017) $\mathrm{CO}_{2}$ emission in India: trends and management at sectoral, sub-regional and plant levels, Carbon Management. 8(2): 111-123. 
Gera M (2012) Poplar culture for speedy carbon sequestration in India: a case study from Terai region of Uttarakhand. Envis Forestry Bulletin 12: 75-83.

Ghosh S C(2019) Nature of boundary and other faults in Raniganj Gondwana rift basin. In Acharya SK (Ed) Developments in Structural Geology and Tectonics. Elsevier, Amsterdam, pp 33-44. ISBN: 978-0-12-815218-8

Gholami R, Raza A, Iglauer S (2021) Leakage risk assessment of a $\mathrm{CO}_{2}$ storage site: A review. Earth-Science Reviews223: 103849. https://doi.org/10.1016/j.earscirev.2021.103849

Gibbins J, Chalmers H (2008) Carbon capture and storage. Energy Policy 36(12); 4317-4322. https://doi.org/10.1016/j.enpol.2008.09.058

Gleason H A(1920) Some applications of the quadrat method. Bulletin of the Torrey Botanical Club 47(1): 21-33. https://doi.org/10.2307/2480223

Gleick PH (2014)Water, Drought, Climate Change, and Conflict in Syria. Weather, Climate, and Society 6(3); 331-340. doi:10.1175/wcas-d-13-00059.1

Global CCS Institute (2012) Fact Sheet Transporting $\mathrm{CO}_{2}$. Global CCS Institute.

Global CCS Institute (2019) Dalmia Cement (Bharat) Limited and Carbon Clean Solutions team up to build cement industry's largest Carbon Capture plant. Global CCS Institute.

Global CCS Institute (2020) Global Status of CCS 2020. Global CCS Institute. 
Goel M (2008) Carbon Capture and Storage, Energy Future and Sustainable Development: Indian Perspective. 2008. Goel M, Kuma, Charan SN (Eds) Carbon Capture and Storage: R\&D Technologies for Sustainable Energy Future. Narosa Publishing House, New Delhi, pp. 1-14. ISBN: 978-81-7319-944-8.

Goel M, Pal R, Sharma A (2021b) An Assessment of CO 2 Reduction Potential from Carbon Sequestration Versus Renewable Energy Targets in India. In: Goel M, Satyanarayana T, Sudhakar M, Agrawal DP. (Eds.) Climate Change and green chemistry of CO2 sequestration. Springer, Singapore, pp 27-45. ISBN: 978-981-16-0028-9.

Goel M, Satyanarayana T, Sudhakar M, Agarwal DP (2021a). Preface.In: Goel M, Sudhakar SM, Agrawal DP. (Eds.) Climate Change and green chemistry of CO2 sequestration. Springer, pp vii-x. ISBN: 978-981-16-0028-9.

Goff F,Lackner KS(1998)Carbon dioxide sequestering using ultramafic rocks. Environmental Geosciences 5(3): 89-101.

GopanA,Kumfer B M, Phillips J,Thimsen D, Smith R, Axelbaum R L(2014) Process design and performance analysis of a Staged, Pressurized Oxy-Combustion (SPOC) power plant for carbon capture. Applied Energy 125: 179-188. https://doi.org/10.1016/j.apenergy.2014.03.032 
Government of India (2020a). The year at a glance in annual report 2020-21. Ministry of Coal GOI.

Government of India (2020b). Indian Petroleum and Natural Gas statistics 2019-20. Ministry of Petroleum and Natural Gas. GOI.

Govindaraju M, Banu J F, \& Goel M (2021). CO 2 Sequestration Through Phytoremediation Techniques with Special Emphasis on Urban Forestry to Mitigate Climate Change Impact.In: Goel M, Satyanarayana T, Sudhakar M, Agrawal DP. (Eds.) Climate Change and green chemistry of CO2 sequestration. Springer, Singapore, pp 263-271. ISBN: 978-981-16-0028-9.

Gozalpour F, Ren S R, Tohidi B (2005) $\mathrm{CO}_{2}$ Eor and Storage in Oil Reservoir. Oil \& Gas Science and Technology 60(3): 537-546. doi:10.2516/ogst:2005036

Gupta A, Paul A (2019) Carbon capture and sequestration potential in India: a comprehensive review. Energy Procedia,160: 848-855

Gupta R K, Kumar V, Sharma K R, Buttar T S, Singh G, Mir G (2017) Carbon sequestration potential through agroforestry: A review. International Journal of Current Microbiology and Applied Science 6(8), 211-220. Doi:10.20546/ijcmas.2017.608.029 
Gyani, O. N., \& Mitra, S. (2021). Challenges in Mature Field Redevelopment. In: Bhui U K (Ed) Macromolecular Characterization of Hydrocarbons for Sustainable Future: Applications to Hydrocarbon Value Chain. Springer, Singapore, pp 35 -42. ISBN 978-981-33-6133-1

Hansen J, Sato M, Kharecha P, Beerling D, Berner R, Masson-Delmotte V, Zachos J C (2008) Target atmospheric CO2: Where should humanity aim? arXiv preprint arXiv:0804.1126. Doi: $\underline{10.2174 / 1874282300802010217}$

Harde H(2017). Scrutinizing the carbon cycle and CO 2 residence time in the atmosphere. Global and Planetary Change 152: 19-26. doi: 10.1016/j.gloplacha.2017.02.009

Hardisty P E, Sivapalan M, Brooks P (2011) The environmental and economic sustainability of carbon capture and storage. International Journal of Environmental Research and Public Health 8(5): 1460-1477. https://doi.org/10.3390/ijerph8051460

Hargis C W, Chen I A, Devenney M, Fernandez M J, Gilliam R J, Thatcher R P (2021) Calcium Carbonate Cement: A Carbon Capture, Utilization, and Storage (CCUS) Technique. Materials 14(11): 2709.

Haszeldine R S(2009) Carbon capture and storage: how green can black be? Science 325 (5948): 1647-1652. 
HendriksC A, Blok K(1995)Underground storage of carbon dioxide. Energy Conversion and Management 36(6-9): 539-542. doi:10.1016/0196-8904(95)00062-i

HerzogH(2009)Carbon dioxide capture and storage, chapter 13. In: Helm D, Hepburn C (eds) Economics and politics of climate change. Oxford University Press, Oxford, pp 263-283. ISBN 9780199573288

Herzog H, Caldeira K, AdamsE(2001) Carbon sequestration via directinjection. Encyclopedia of Ocean Sciences 1: 408-414.

Herzog H, Eliasson B, Kaarstad O(2002) Capturing greenhouse gases. Sci. Am. 282: 72 80. DOI: $10.1038 /$ scientificamerican0200-72

Holloway S, Garg A, Singh AK, Mahmood MA, Khan SR, Kirk KL, Vincent CJ, Williams J, Gale J(2008) GIS as a tool for mapping $\mathrm{CO}_{2}$ source and storage sites. In: Goel M, Kuma, Charan SN (Eds) Carbon Capture and Storage: R\&D Technologies for Sustainable Energy Future. Narosa Publishing House, New Delhi,pp. 97-101. ISBN: 978-81-7319-944-8.

HollowayS, Garg A, Kapshe M, Deshpande A, Pracha AS, Khan S R, Gale J (2009) An assessment of the $\mathrm{CO}_{2}$ storage potential of the Indian subcontinent. Energy Procedia 1:26072613. 
Huijts N M, Molin E J, Steg L (2012) Psychological factors influencing sustainable energy technology acceptance: A review-based comprehensive framework. Renewable and sustainable energy reviews 16(1): 525-531. https://doi.org/10.1016/j.rser.2011.08.018

HydeWT, Crowley T J, Baum SK, PeltierW R (2000) Neoproterozoic 'snowball Earth' simulations with a coupled climate/ice-sheet model. Nature 405 (6785): 425-429.

IEA Greenhouse Gas R \& D program (2008). “A regional assessment of the potential for CO2 storage in the Indian subcontinent”. International energy agency.

IEA (2019) The Role of CO2 Storage. IEA Paris. https://www.iea.org/reports/the-role-of-co2storage. (Accessed 05-Sept-2021)

Intergovernmental Panel on Climate Change (2018). Global warming of $1.5^{\circ} \mathrm{C}$. An IPCC Special Report on the impacts of global warming of $1.5^{\circ} \mathrm{C}$ above pre-industrial levels and related global greenhouse gas emission pathways, in the context of strengthening the global response to the threat of climate change. IPCC. https://www.ipcc.ch/sr15/

International Energy Agency (2020a). India 2020: Energy Policy Review. IEA Publications.

International Energy Agency (2020b). Energy Technology Perspectives. IEA Publications. 
International Energy Agency (2021). India Energy Outlook 2021. IEA Publications.

IEAGHG (2013). A Brief History of CCS and Current Status. In: Information sheets for CCS. IEAGHG. pp. 4.

Internet reference: https://www.climatewatchdata.org/ (Accessed 30-Oct-2020)

Harrabin R (2017)Indian firm makes carbon capture breakthrough. The guardian https://irade.org/ccs/session\%207B/11.\%20Mr\%20A\%20B\%20Chakraborty.ppt (Accessed 22October 2020) https://www.theguardian.com/environment/2017/jan/03/indian-firm-carboncapture-breakthrough-carboncleanAccessed 21 June 2018

Helwani Z, WiheebAD, Kim J, Othman M R (2016) In-situ mineralization of carbon dioxide in a coal-fired power plant. Energy Sources, Part A: Recovery, Utilization, and Environmental Effects 38(4): 606-611.https://doi.org/10.1080/15567036.2013.813991

Henry M, Bombelli A, Trotta C, Alessandrini A, Birigazzi L, Sola G, Vieilledent G, Santenoise P, Longuetaud F, Valentini R, Picard N, Saint-André L (2013)GlobAllomeTree: international platform for tree allometric equations to support volume, biomass and carbon assessment. iForest - Biogeowcience and Forestry 6: 326-330. doi: 10.3832/ifor0901-006 
Gu H, Shen L, Niu ZZX, Liu W, Ge H, Jiang S, Wang L. (2015) Cement/CaO-modified iron ore as oxygen carrier for chemical looping combustion of coal. Applied Energy 157: 314-322. https://doi.org/10.1016/j.apenergy.2015.06.023

Gupta U (2021)Indian Oil selects American firm Dastur for India's largest industrial carbon capture and utilization project. https://www.pv-magazine-india.com/2021/02/17/indianoilselects-american-firm-dastur-for-indias-largest-industrial-carbon-capture-and-utilization-project/ (Accessed 03 July 2021)

IPCC (Intergovernmental Panel on Climate Change) 2003. Good practice guidance for land use, land-use change and forestry. Japan, Institute for Global Environment Strategies.

Javid M, Khan M (2020). Energy efficiency and underlying carbon emissiontrends. Environmental Science and Pollution Research27(3): 3224-3236.

J.M.K.C. Donev et al. (2018). Energy Education - Supercritical coal plant.https://energyeducation.ca/encyclopedia/Supercritical coal plantAccessed 06 June 2021.

Jain N, Srivastava A, Singh T N (2016) Carbon Capture, Transport and Geologic Storage: A Brief Introduction. In: (Eds) Geologic Carbon Sequestration: Understanding Reservoir Behaviour. Springer, Cham, pp. 3-18. ISBN 978-3-319-27019-7. 
Jia X, Luo M, Pu H (2020) Numerical simulation of $\mathrm{CO}_{2}$ huff-and-puff process in a hydraulically fractured horizontal well in a tight oil reservoir. The Leading Edge 39(1): 1621. doi:10.1190/tle39010016.1

Kambale JB, Tripathi V K (2010) Biotic and abiotic processes as a carbon sequestration strategy. J. Environ. Res. Develop 5(1): 240-251.

Kanjilal B, Nabavinia M, Masoumi A, Savelski M, \&Noshadi I (2020). Challenges on CO2 capture, utilization, and conversion. In: Mohammad Reza Rahimpour, Mohammad Farsi, Mohammad Amin Makarem (Eds) Advances in Carbon Capture. Woodhead Publishing, Duxford, pp 29-48. ISBN 9780128196571

Kanniche M, Bouallou C(2007) CO2 capture study in advanced integrated gasification combined cycle. Applied Thermal Engineering 27(16): 2693-2702.

Karmakar G P (2016) Carbon Dioxide sequestration during enhanced oil recovery: Operational and economical aspects. J. Indian Geophys Union 1: 5-12.

Khadka NS (2015) India 'will not announce' carbon emissions peak year. BBC.

https://www.bbc.com/news/world-asia-india-33353181. Accessed 02 September 2021 
Kirikkaleli D, Adebayo, T.S (2021) Do public-private partnerships in energy and renewable energy consumption matter for consumption-based carbon dioxide emissions in India?. Environ Sci Pollut Res 28: 30139-30152 . https://doi.org/10.1007/s11356-021-12692-5

Knutson T R, McBride JL, Chan J, Emanuel K, Holland G et al (2010) Tropical cyclones and climate change. Nature Geoscience 3(3): 157-163. https://doi.org/10.1038/ngeo779

Koide H, Tazaki Y, Noguchi Y, Nakayama S, Iijima M, Ito K, Shindo Y (1992) Subterranean containment and long-term storage of carbon dioxide in unused aquifers and in depleted natural gas reservoirs. Energy Conversion and Management 33(5-8): 619-626. doi:10.1016/01968904(92)90064-4

Krawczyk C M, Tanner D C, Henk A, Trappe H, Ziesch J, Beilecke T, Aruffo CM, Weber B, Lippmann A, Görke U-J, Bilke L, Kolditz O. (2015) Seismic and sub-seismic deformation prediction in the context of geological carbon trapping and storage. In: Liebscher A, Munch U (Eds) Geological Storage of $\mathrm{CO}_{2}$-Long Term Security Aspects. Springer, pp. 97-113. ISBN 9783-319-13930-2.

Krunal Kalbende (2015). Carbon Capture and Storage in Geological Formation; Its Legal, Regulatory Imperatives and Opportunities in India. International Journal of Environmental Monitoring and Analysis 3: 198-204. 
Kumar A, Pal S, Srivastava JP (2020) Contemporary researches and issues related to the Deccan volcanism. Proc Indian Natn Sci Acad86: 245-261. Doi: 10.16943/ptinsa/2020/49791

Kumar B, Charan SN, Menon R, Pamicker SK. (2008). Geological $\mathrm{CO}_{2}$ sequestration in the basalt formation of western India: A feasibility study. In: Goel M, Kuma, Charan SN (Eds) Carbon Capture and Storage: R\&D Technologies for Sustainable Energy Future. Narosa Publishing House, New Delhi, pp. 105-110. ISBN: 978-81-7319-944-8.

Kumar B (2015) Options for $\mathrm{CO}_{2}$ Storage and its Role in Reducing $\mathrm{CO}_{2}$ Emissions. In: Goel M, Sudhakar M, Shahi RV (Eds) Carbon Capture, Storage and, Utilization: A possible climate change solution for energy industry. New Delhi, TERI. pp 123-131. ISBN 978-81-7993-568-2.

Kumar P, Parwani A K(2021) CFD Analysis of Chemical Looping Combustion with Special Emphasis on Indian Coal: A Review. In: Goel M, Satyanarayana T, Sudhakar M, Agrawal DP. (Eds.) Climate Change and green chemistry of $\mathrm{CO}_{2}$ sequestration. Springer, Singapore, pp 57-68. ISBN: 978-981-16-0028-9.

Kumar P, Kumar P, Sharma M, Butail N P, Shukla A K (2021) Quantification of the Soil Organic Carbon and Major Nutrients Using Geostatistical Approach for Lahaul Valley, Cold Arid Region of Trans-Himalaya. In: Pant D, Nadda A K, Pant K K, Agarwal A K (Eds) Advances in Carbon Capture and Utilisation. Springer, Singapore, pp. 235 - 247. ISBN: 978981-16-0638-0 
Kumar R, Jilte R, Nikam K C, Ahmadi M H (2018) Status of carbon capture and storage in India's coal fired power plants: A critical review. Environmental Technology \& Innovation. doi:10.1016/j.eti.2018.10.013

Kurinjimalar R, Prasanna N (2017) Impact of MGNREGP on poverty alleviation in Rural India: A Case study of two Districts in Tamil Nadu. Journal of Academia and Industrial Research (JAIR) 5(9): 139.

Lal R(2004) Soil carbon sequestration in India. Climatic Change 65(3): 277-296.

LalR(2008)Carbon sequestration. Philosophical Transactions of the Royal Society B: Biological Sciences 363: 815-830.

Lal R(2010) Terrestrial sequestration of carbon dioxide $\left(\mathrm{CO}_{2}\right)$. In: Maroto-Valer MM (Ed) Developments and Innovation in Carbon Dioxide $\left(\mathrm{CO}_{2}\right)$ Capture and Storage Technology. Woodhead Publishing, pp. 271-303.

Lau H C, Ramakrishna S, Zhang K, Radhamani A V (2021). The Role of Carbon Capture and Storage in the Energy Transition. Energy Fuels 202135 (9):7364-7386.

https://doi.org/10.1021/acs.energyfuels.1c00032 
Le Quéré et al (2020) Temporary reduction in daily global $\mathrm{CO}_{2}$ emissions during the COVID-19 forced confinement. Nature Climate Change 10: 647-653. https://doi.org/10.1038/s41558-0200797-x

Leeson D, Mac Dowell N, Shah N, Petit C, Fennell P S (2017) A Techno-economic analysis and systematic review of carbon capture and storage (CCS) applied to the iron and steel, cement, oil refining and pulp and paper industries, as well as other high purity sources. International Journal of Greenhouse Gas Control, 61, 71-84. https://doi.org/10.1016/j.ijggc.2017.03.020

Lema A, Lema R(2013) Technology transfer in the clean development mechanism: Insights from wind power. Global Environmental Change 23(1): 301-313.

Leung D Y, Caramanna G, Maroto-Valer M M (2014) An overview of current status of carbon dioxide capture and storage technologies. Renewable and Sustainable Energy Reviews39: 426443. https://doi.org/10.1016/j.rser.2014.07.093

Li Z, Dong M, LiS, Huang S(2006) $\mathrm{CO}_{2}$ sequestration in depleted oil and gas reservoirs-cap rock characterization and storage capacity. Energy Conversion and Management 47: 1372-1382. https://doi.org/10.1016/j.enconman.2005.08.023 
Liang $\mathrm{Z}$ et al (2015) Recent progress and new developments in post-combustion carbon-capture technology with amine based solvents. Int. J. Greenhouse Gas Control 40: 26-54.

https://doi.org/10.1016/j.ijggc.2015.06.017

Lisbona P, Bailera M, Peña B, Romeo LM (2020) Integration of CO2 capture and conversion. In: Mohammad Reza Rahimpour, Mohammad Farsi, Mohammad Amin Makarem (Eds) Advances in Carbon Capture. Woodhead Publishing, Duxford, pp 503-522. ISBN: 9780128196571

Liu B, Zhang M, Wang T, Jia W(2019) Process simulation of CO 2 capture from CO 2-EOR associated petroleum gas with aqueous MEA and MDEA solvents. Energy Science \& Engineering 7(3): 663-675.https://doi.org/10.1002/ese3.308

Liu P, Zhang T, Sun S(2019) A tutorial review of reactive transport modeling and risk assessment for geologic $\mathrm{CO}_{2}$ sequestration. Computers \& Geosciences127: 1-11. doi: $\underline{10.1016 / j . c a g e o .2019 .02 .007}$

Liu Z et al (2020) Near-real-time monitoring of global CO 2 emissions reveals the effects of the COVID-19 pandemic. Nature Communications 11(1): 1-12.

Liu Z, Deng Z, Ciais P, Lei R, Feng S, Davis S J, Cai Z (2020). Decreases in global $\mathrm{CO}_{2}$ emissions due to COVID-19 pandemic. arXiv preprint arXiv:2004:13614. 
Lorenz K, Lal R(2010) Carbon sequestration in Forest ecosystem. Springer Science \& Business Media. Springer. pp. 23-26. ISBN 978-90-481-3266-9.

Lu H, Ma X, Huang K, Fu L, Azimi M(2020) Carbon dioxide transport via pipelines: A systematic review. Journal of Cleaner Production266: 121994

https://doi.org/10.1016/j.jclepro.2020.121994

Maalim A A, Mahmud H B, Seyyedi M (2021). Assessing roles of geochemical reactions on CO2 plume, injectivity and residual trapping. Energy Geoscience2(4): 327-336.

Mahajan M S, Rasheed M A, Rao P L S, Bhutiya P, HasanS Z, \& Shah S (2021). CO 2 Biosequestration Studies on Microalgae-An Approach ThroughSustainable Biofuel Production. In: Bhui U K (Ed) Macromolecular Characterization of Hydrocarbons for Sustainable Future: Applications to Hydrocarbon Value Chain. Springer, Singapore, pp 275 - 286. ISBN 978-98133-6133-1

Maji P (2019) Access to modern energy, air pollution and greenhouse gas mitigation: Interlinking three major energy challenges facing India today. Dissertation. University of British Columbia. Pp1-249.

Malhotra S K (2017) Horticultural crops and climate change: A review. Indian Journal of Agricultural Sciences 87(1): 12-22. 
Mani D,Charan S N, Kumar B(2008) Assessment of carbon dioxide sequestration potential of ultramafic rocks in the greenstone belts of southern India. Current Science 94(1): 53-60.

MariyammaP N, Yan S, Tyagi R D, Surampalli R Y, Zhang T C (2015) CO2 sequestration and leakage. In Surampalli R Y, Zhnag T C, Tyagi R D, Naidu R, Gurjar B R, Ojha C S P, Yan S, Brar S K, Ramakrishnan A, Kao C M. (Eds.) Carbon Capture and Storage: Physical, Chemical, and Biological Methods. American Society of Civil Engineers, Virginia, pp 113-157. ISBN 978$0-7844-7891-2$

Martens S et al (2015) Joint research project CO 2 MAN (CO 2 MAN reservoir management): continuation of research and development work for CO 2 storage at the Ketzin pilot site. In: Liebscher A, Munch U (Eds) Geological Storage of $\mathrm{CO}_{2}$-Long Term Security Aspects. Springer, pp 1 -32 ISBN 978-3-319-13930-2

Mathews WR, Kelly J (1967) How to Predict Formation Pressures and Fracture Gradient from electric and Sonic Logs. Oil and Gas Journal 65: 92-106.

McGrail BP, Schaef HT, Spane FA (2008). New findings regarding carbon dioxide sequestration in flood basalts. In: Goel M, Kuma, Charan SN (Eds) Carbon Capture and Storage: R\&D Technologies for Sustainable Energy Future. Narosa Publishing House, New Delhi, pp. 15-21. ISBN: 978-81-7319-944-8. 
McGrail BP, Schaef HT, Spane FA. (2008). New findings regarding carbon dioxide sequestration in flood basalts. In: Goel M, Kuma, Charan SN (Eds) Carbon Capture and Storage: R\&D Technologies for Sustainable Energy Future. Narosa Publishing House, New Delhi, pp 1521. ISBN: 978-81-7319-944-8.

McGrail BP, Schaef H T, Ho A M,Chien Y J, Dooley J J, Davidson C L (2006) Potential for carbon dioxide sequestration in flood basalts. Journal of Geophysical Research: Solid Earth 111 (B12201).

Meinshausen M, Dooley K (2019) Mitigation Scenarios for Non-energy GHG. In: Teske S. (eds) Achieving the Paris Climate Agreement Goals. Springer, Cham, pp 79-91. ISBN 978-3$030-05843-2$

Merkel T C, Lin H, Wei X, Baker R (2010) Power plant post-combustion carbon dioxide capture: An opportunity for membranes. Journal of Membrane Science 359(1-2): 126-139. Ministry of Power, Government of India (2021). Power sector at a glance. https://powermin.gov.in/en/content/power-sector-glance-all-india (Accessed on 03 July 2021)

Ministry of Science and Technology, Government of India (2018) Funding Opportunity Announcement (FOA) in Carbon Capture Innovation Challenge (IC\#3) jointly by Department of Biotechnology \& Department of Science and Technology. http://dst.gov.in/sites/default/files/FOA-IC3.pdf Accessed 19 September 2021 
Mishra, G. K., Meena, R. K., Mitra, S., Saha, K., Dhakate, V. P., Prakash, O., \& Singh, R. K. (2019). Planning India's First CO-EOR Project as Carbon Capture Utilization \& Storage: A Step Towards Sustainable Growth. SPE Oil and Gas India Conference and Exhibition. doi:10.2118/194629-ms

Misra A A, Mukherjee S(2015). Dyke-brittle shear relation in the western Deccan Traps near Mumbai, India. In Tectonic Studies Group Annual Meeting (pp. 6-8).

Mohan RR, Dharmala N, Ananthakumar M R, Kumar P, Bose A (2019) Greenhouse Gas Emission Estimates from the Energy Sector in India at the Subnational Level (Version/edition 2.0). New Delhi. GHG Platform India Report - CSTEP. http://www.ghgplatformindia.org/methodology-electricityenergysector (Accessed on 31-May-2021).

Moharana P C, Jena R K, Kumar N, Singh R S, Rao S S (2021) Assessment of soil organic and inorganic carbon stock at different soil depths after conversion of desert into arable land in the hot arid regions of India. Carbon Management 12(2): 153-165. https://doi.org/10.1080/17583004.2021.1893128

Mir A H, Chaudhury G, Barbhuyan H S A, Sarma K, Upadhaya K (2021) Impact of disturbance on community structure, biomass and carbon stock in montane evergreen forests of Meghalaya, 
northeast

India. Carbon

Management12(2):

215-233.

https://doi.org/10.1080/17583004.2021.1899752

Mokhatab S, Poe W A, Speight J G (2012) Chapter 10-Natural gas liquids recovery. In:

Mokhatab S, Poe WA. (Ed) Handbook of Natural Gas Transmission and Processing 2: 353-391.

Mokhtar M, AliMT, Khalilpour R, Abbas A, Shah N, Al HajajA, Sgouridis, S. (2012) Solarassisted post-combustion carbon capture feasibility study. Applied Energy 92: 668-676. https://doi.org/10.1016/j.apenergy.2011.07.032

Mondal M, Goswami S, Ghosh A,Oinam G, TiwariO N, Das P,Gayen K, Mandal MK, Halder G N (2017) Production of biodiesel from microalgae through biological carbon capture: a review. 3 Biotech 7(2), 99. https://doi.org/10.1007/s13205-017-0727-4

Mukherjee S, Dole G, Yatheesh V, Kale V (2020) Tectonics of the Deccan trap: Focus on Indian Geoscientists' Contribution in the Last Four Years. Proceedings of the Indian National Science Academy 86: 237-244.

Mukherjee S, Misra AA, Calvès G, Nemčok M (2017) Tectonics of the Deccan Large Igneous Province: an introduction. In: Mukherjee S, Misra AA, Calvès G, Nemčok M. (Eds) Tectonics of the Deccan Large Igneous Province. Geological Society, London, Special Publications 445: 1-9. 
Mukherjee A, Bose A, Kumar A (2014) TERI's Scoping Study on Carbon Capture and Storage in the Indian Context. In: Goel M, Sudhakar M, Shahi RV (Eds) Carbon Capture, Storage and, Utilization: A possible climate change solution for energy industry. CRC press, London, pp5768. ISBN 9780367179083.

Mukhopadhyay A(2019) Jharia Basin Structure and Tectonics. In Acharya SK (Ed) Developments in Structural Geology and Tectonics. Elsevier, Amsterdam, pp 45-54. ISBN: 9780-12-815218-8

Murthy I K, Gupta M, Tomar S, Munsi M, Tiwari R, Hegde GT, Ravindranath N H (2013)

Carbon sequestration potential of agroforestry systems in India. J Earth Sci Climate Change 4(1) :1-7. doi: 10.4172/2157-7617.1000131

Nahar D, Verma P (2018) Shaping public behavior and green consciousness in India through the 'Yo!Green'Carbon Footprint Calculator. Carbon $\quad$ Management9(2): 127-144. https://doi.org/10.1080/17583004.2018.1435960

Nahlik A M, Fennessy M S (2016) Carbon storage in US wetlands. Nature Communications 7(1): 1-9.

Nair PK R, Kumar M B, Nair V D (2009). Agroforestry as a strategy for carbon sequestration. Journal of plant nutrition and soil science, 172(1): 10-2310.1002/jpln.200800030 
Nanoni A, Goswami AN (2010). Post combustion capture of $\mathrm{CO}_{2}$. In: Qasim SZ, Goel M. CO2 Sequestration Technologies for Clean Energy: Awareness and Capacity Building. Daya Publishing House, Delhi, pp 41-51. ISBN 81-7035-660-8.

Nazarnia H, Nazarnia M, Sarmasti H, Wills W O (2020) A systematic review of civil and environmental infrastructures for coastal adaptation to sea level rise. Civil Engineering Journal6(7): 1375-1399.DOI: 10.28991/cej-2020-03091555

Newaj R, Rizvi RH, Chaturvedi OP, Alam B, Prasad R, Kumar D, Handa AK (2017) A country level assessment of area under agroforestry and its carbon sequestration potential. Technical bulletin 2/2017, ICAR- Central Agroforestry Research Institute, Jhansi: 1-48

Niharika, Chaudhary Y S, Basu S (2021) $\mathrm{CO}_{2}$ Conversion into Chemicals and Fuel: India's Perspective.In: Goel M, Satyanarayana T, Sudhakar M, Agrawal DP. (Eds.) Climate Change and green chemistry of CO2 sequestration. Springer, Singapore, pp 105-122. ISBN: 978-981-16$0028-9$.

Noble R R, Stalker L, Wakelin S A, Pejcic B, Leybourne M I, Hortle A L, Michael K (2012) Biological monitoring for carbon capture and storage-a review and potential future developments. International Journal of Greenhouse Gas Control10: 520-535. https://doi.org/10.1016/j.ijggc.2012.07.022 
Nord L O,Anantharaman R, Rausand M, Bolland O(2009) A qualitative reliability and operability analysis of an integrated reforming combined cycle plant with $\mathrm{CO}_{2}$ capture. International Journal of Greenhouse Gas Control 3(4): 411-421. DOI: https://doi.org/10.1016/j.ijggc.2009.02.004

Onishi T, Nguyen M C, Carey J W, Will B, Zaluski W, Bowen D W, Stauffer PH (2019). Potential $\mathrm{CO}_{2}$ and brine leakage through wellbore pathways for geologic $\mathrm{CO}_{2}$ sequestration using the National Risk Assessment Partnership tools: Application to the Big Sky Regional Partnership. International Journal of Greenhouse Gas Control 81: 44-65. doi:10.1016/j.ijggc.2018.12.002

Onyeaka H, Miri T, Obileke K, Hart A, Anumudu C, Al-Sharify Z T (2021) Minimizing carbon footprint via microalgae as a biological capture. Carbon Capture Science \& Technology 1: 100007. https://doi.org/10.1016/j.ccst.2021.100007

Osman A I, Hefny M, Abdel Maksoud M I A, Elgarahy A M, Rooney D W (2020). Recent advances in carbon capture storage and utilisation technologies: a review. Environmental Chemistry Letters 19(2): 797-849. https://doi.org/10.1007/s10311-020-01133-3

Padurean A, Cormos C C, Agachi P S (2012) Pre-combustion carbon dioxide capture by gasliquid absorption for Integrated Gasification Combined Cycle power plants. International Journal of Greenhouse Gas Control 7: 1-11. https://doi.org/10.1016/j.ijggc.2011.12.007 
Pal D K, Wani S P, Sahrawat K L (2015) Carbon sequestration in Indian soils: present status and the potential. Proceedings of the National Academy of Sciences, India Section B: Biological Sciences85(2) :337-358.

PalD K, Wani S P, Sahrawat K L (2015) Carbon sequestration in Indian soils: Present status and the potential. Proceedings of the National Academy of Sciences, India Section B: Biological Sciences 85(2): 337-358. Doi: 10.1007/s40011-014-0351-6

Paltsev S, Morris J, Kheshgi H, Herzog H (2021) Hard-to-Abate Sectors: The role of industrial carbon capture and storage (CCS) in emission mitigation. Applied Energy 300: 117322.

Pandey C N,Pandey R (2013) Carbon sequestration in mangroves of Gujarat, India. International Journal of Botany and Research3(2): 57-70.

PandeyD (2007) Multifunctional agroforestry systems in India. Current Science92(4): 455-463. https://www.jstor.org/stable/24097558

Pant D, Nadda A K, Pant K K, Agarwal A K (2021) Preface. In: Pant D, Nadda A K, Pant K K, Agarwal A K (Eds) Advances in Carbon Capture and Utilisation. Springer, Singapore, pp. v viii. ISBN: 978-981-16-0638-0

Pérez-Fortes M, Moya J A, Vatopoulos K, Tzimas E (2014) CO2 capture and utilization in cement and iron and steel industries. Energy Procedia, 63, 6534-6543.

https://doi.org/10.1016/j.egypro.2014.11.689 
Perumal P J (2021) What is the extent of India's coal crisis?

https://www.thehindu.com/business/Economy/explained-what-is-the-extent-of-indias-coalcrisis/article37032323.ece\#: :text=The\%20current\%20crisis\%20in\%20the, worth\%20of\%20coal \%20in\%202018 Accessed $23^{\text {rd }}$ October 2021

Piessens K (2012) The conceptual model for an abandoned coal mine reservoir. In: He M, Ribeiro e Sousa L, Elsworth D, Vargas Jr E (Eds) $\mathrm{CO}_{2}$ storage in carboniferous formations and abandoned mines. CRC Press, Boca Raton, pp. 179-200. ISBN: 978-0-415-62079-6.

Potdar R S, Vishal V(2016) Trapping Mechanism of CO2 Storage in Deep Saline Aquifers: Brief Review. In: Vishal V, Singh TN (Eds) Geologic Carbon Sequestration: Understanding Reservoir Behaviour. Springer, Cham, pp. 47-58.ISBN 978-3-319-27019-7

Pradhan R R, Pradhan RR, Das S, Dubey B, Dutta A(2017) Bioenergy combined with carbon capture potential by microalgae at flue gas-based carbon sequestration plant of NALCO as accelerated carbon sink. In: Goel M, Sudhakar M (Ed) Carbon Utilization. Springer, Singapore, pp. 231-244. ISBN 978-981-10-3351-3.

Prospero, J. M., \& Lamb, P. J. (2003). African droughts and dust transport to the Caribbean: Climate change implications. Science 302 (5647): 1024-1027. Doi: 10.1126/science.1089915

Punnam P R, Krishnamurthy B, Surasani V K (2021) Investigations of Structural and Residual Trapping Phenomena during CO2 Sequestration in Deccan Volcanic Province of the Saurashtra 
Region, Gujarat. International Journal of Chemical Engineering 2021.

https://doi.org/10.1155/2021/7762127

Qiao Y, Wu C (2022) Nitrogen enriched biochar used as CO2 adsorbents: a brief review. Carbon Capture Science \& Technology 2: 100018.

Radha A V, Navrotsky A (2013) Thermodynamics of carbonates. Reviews in Mineralogy and Geochemistry 77(1): 73-121. https://doi.org/10.2138/rmg.2013.77.3

Radio free Europe radio liberty (2018). At least 23 killed in mine disaster in Pakistan. RFERL https://www.rferl.org/a/pakistan-balochistan-mine-explosion/29210895.html (Accessed 21 June 2018)

Ragula A \& Chandra K K (2020) Tree species suitable for roadside afforestation and carbon sequestration in Bilaspur, India. Carbon Management11(4): 369-380. https://doi.org/10.1080/17583004.2020.1790243।

Rajan A, Ghosh K, Shah A (2020) Carbon footprint of India's groundwater irrigation. Carbon Management 11(3): 265-280. https://doi.org/10.1080/17583004.2020.1750265 
Ranjan et al. (2018) Carbon capture, utilization and storage (CCUS) - a roadmap for India, Technology Information Forecasting and Assessment Council. Ministry of Science and Technology, Government of India.

Raha D, Dar JA, Pandey PK, Lone PA, Verma S, Khare PK, Khan ML (2020) Variation in tree biomass and carbon stocks in three tropical dry deciduous forest types of Madhya Pradesh, India. Carbon Management11(2): 109-120. https://doi.org/10.1080/17583004.2020.1712181

Rani V, Nandan S B,Schwing P T (2021) Carbon source characterisation and historical carbon burial in three mangrove ecosystems on the South-West coast of India. CATENA197 :104980. Doi: $10.1007 / \mathrm{s} 40011-014-0351-6$

Rathnaweera T D, Ranjith P G (2020) Nano-modified CO2 for enhanced deep saline CO2 sequestration: A review and perspective study. Earth-Science Reviews200: 103035. https://doi.org/10.1016/j.earscirev.2019.103035

Ravan S V (2014) Impact of LPG on Indian Economy. Prime International Research Journal 1(4), 21-33.

Ray A(2021) Carbon Capture and Sequestration: Implications and Opportunities for India. In: Goel M, Satyanarayana T, Sudhakar M, Agrawal DP. (Eds.) Climate Change and green chemistry of CO2 sequestration. Springer, Singapore, pp 19-25. ISBN: 978-981-16-0028-9. 
RCN (2018) The Norwegian Programme for Research Cooperation with India - INDNOR. Oslo: Research Council of Norway.

REN21 (2020). Global Overview. In: Renewables 2020 Global Status Report (Paris: REN21 Secretariat). ISBN 978-3-948393-00-7

Ribeiro e Sousa L (2012). Present day conditions in the world of Carbon Capture and Storage (CCS) projects. In: He M, Ribeiro e Sousa L, Elsworth D, Vargas Jr E (Eds) $\mathrm{CO}_{2}$ storage in carboniferous formations and abandoned mines. CRC Press, Boca Raton, pp 1-24. ISBN: 978-0415-62079-6.

Riley N (2010) Geological storage of carbon dioxide. In Hester R, Harrison R (Eds) Carbon Capture: Sequestration and Storage. Royal Society of Chemistry, Great Britain, pp 155 - 178. ISBN 978-1-84755-917-3.

Ringrose $\mathrm{P}(2020)$ How to Store $\mathrm{CO}_{2}$ Underground: Insights from early-mover CCS Projects .Springer, Switzerland. ISBN 978-3-030-33113-9

Robiou du Pont Y, Jeffery M, Gütschow J, Rogeli J, Christoff P, Meinshausen M (2017) Equitable mitigation to achieve the Paris Agreement goals. Nature Climate Change 7: 38-43. https://doi.org/10.1038/nclimate3186 
Rootzén J M,BerndesG,Ravindranath N H,Somashekar H I, Murthy IK, Sudha P, Ostwald M(2010) Carbon sequestration versus bioenergy: A case study from South India exploring the relative land-use efficiency of two options for climate change mitigation. Biomass and Bioenergy 34(1): 116-123. https://doi.org/10.1016/j.biombioe.2009.10.008

Rumayor M, Fernández-González J, Domínguez-Ramos A, Irabien A (2021) Deep Decarbonization of the Cement Sector: A Prospective Environmental Assessment of CO2 Recycling to Methanol. ACS Sustainable Chemistry \& Engineering10(1): 267-278. https://doi.org/10.1021/acssuschemeng.1c06118

Sahajwalla V, Maroufi S, Bell G, Bell P, De Bari I (2019) Alternative sustainable carbon sources as substitutes for metallurgical coal. IEA Bioenergy. ISBN, 978-1-910154-67-0

Sahu S, Kumar M,RavindranathN(2016)Carbon stocks in natural and planted mangrove forests of Mahanadi Mangrove Wetland, East Coast of India. Current Science110(12): 2253-2260. DOI: $\underline{10.18520 / \mathrm{cs} / \mathrm{v} 110 / \mathrm{i} 12 / 2253-2260}$

Saleth RM, Galab S, Revathi E(2020) Issues and Challenges of Inclusive Development: Overview and Synthesis. Issues and Challenges of Inclusive Development: 1-24, ISBN 978-981$15-2228-4$ 
Sankar U(2020) Challenges in Achieving Inclusive and Sustainable Growth in India. In: Saleth RM, Galab S, Revathi E (Eds) Issues and Challenges of Inclusive Development: Essays in Honor of Prof. R. Radhakrishna. Springer, Singapore,pp. 71-89. ISBN 978-981-15-2228-4.

SannaA,UibuM,CaramannaG,Kuusik R, Maroto-Valer M M (2014) A review of mineral carbonation technologies to sequester $\mathrm{CO}_{2}$. Chemical Society Reviews 43(23), 8049-8080. https://doi.org/10.1039/C4CS00035H

Schaller M F, Wright J D, Kent D V (2011) Atmospheric pCO2 perturbations associated with the Central Atlantic magmatic province. Science 331(6023), 1404-1409.

Seetharaman, Krishna Moorthy, Nitin Patwa, Saravanan, Gupta Y (2019). Breaking barriers in deployment of renewable energy. Heliyon 5, e01166.

https://doi.org/10.1016/j.heliyon.2019e01166

Seigo S L O, Dohle S, Siegrist M (2014) Public perception of carbon capture and storage (CCS): A review. Renewable and Sustainable Energy Reviews38:848-863.

https://doi.org/10.1016/j.rser.2014.07.017

Sen G (2017) Carbon Sequestration and Utilization—India's Energy Woes. In: Goel M. Sudhakar M. (Eds) Carbon Utilization: Applications for the Energy Industry (Green Energy and Technology) Springer, Singapore, pp. 169-172. ISBN 978-981-10-3352-0. 
Senthilkumar P (2021). Feasibility Study of CO 2 Control in Automobile Sources.In: Goel M, Satyanarayana T, Sudhakar M, Agrawal DP. (Eds.) Climate Change and green chemistry of CO2 sequestration. Springer, Singapore, pp 69-85. ISBN: 978-981-16-0028-9.

Seshadri S, Sashirekha V (2018). Prospects and Limitations in Establishing Integrated Carbon Capture and Wastewater Treatment Facility using Algal and Bacterial Consortia. Workshop on Awareness and Capacity Building in Carbon Capture and Storage and Utilization, pp. 42 - 44, GOI.

Sethi V K (2017) Low Carbon Technologies (LCT) and Carbon Capture \& Sequestration (CCS)Key to Green Power Mission for Energy Security and Environmental Sustainability. In: Goel M, Sudhakar M. (Ed) Carbon Utilization: Applications for the Energy Industry. pp. 45-57. Springer, Singapore. ISBN 978-981-10-3351-3

Shackley S, Verma $\mathrm{P}$ (2008) Tackling $\mathrm{CO}_{2}$ reduction in India through use of $\mathrm{CO}_{2}$ capture and storage (CCS): Prospects and challenges. Energy Policy 36, 3554-3561.

https://doi.org/10.1016/j.enpol.2008.04.003

Shahbaz M, Hoang T H V, Mahalik M K, RoubaudD(2017). Energy consumption, financial development, and economic growth in India: New evidence from a nonlinear and asymmetric analysis. Energy Economics 63: 199-212. doi:10.1016/j.eneco.2017.01.023 
ShahhosseiniHR,SaeidiS,Najari S, Gallucci F(2017) Comparison of conventional and spherical reactor for the industrial auto-thermal reforming of methane to maximize synthesis gas and minimize $\mathrm{CO}_{2}$. International Journal of Hydrogen Energy 42(31): 19798-19809. DOI: https://doi.org/10.1016/j.ijhydene.2017.06.192

Shakti and EY (2018) Discussion Paper on Carbon Tax Structure for India. Ernst \& Young. https://shaktifoundation.in/wp-content/uploads/2018/07/Discussion-Paper-on-Carbon-Tax-

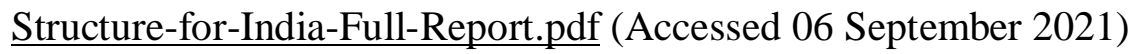

Sharma N (2018) Silver bullet or bitter pill? Reassessing the scope of CO2 capture and storage in India. Carbon Management 9(4): 311-332. https://doi.org/10.1080/17583004.2018.1518108

Sharma R, Pradhan L, Kumari M, Bhattacharya P (2020) Assessment of Carbon Sequestration Potential of Tree Species in Amity University Campus Noida. Environmental Sciences Proceedings 3(1): 52. https://doi.org/10.3390/IECF2020-08075.

Shearer C, Fofrich R, Davis S J (2017) Future CO2 emissions and electricity generation from proposed coal-fired power plants in India. Earth's Future 5(4): 408-416. https://doi.org/10.1002/2017EF000542

Shell Global and TERI (2021). India: Transforming to a net zero emissions energy system. Shell Global and The Energy and resources institute. 
Shirmohammadi R,Aslani A, Ghasempour R(2020) Challenges of carbon capture technologies deployment in developing countries. Sustainable Energy Technologies and Assessments 42: 100837. https://doi.org/10.1016/j.seta.2020.100837

Shukla AK, Ahmad Z, Sharma M, Dwivedi G, Verma T N, Jain S, Verma P, Zare A (2020) Advances of carbon capture and storage in coal-based power generating units in an Indian context. Energies 13(16):4124. Doi: https://doi.org/10.3390/en13164124

Siegelman R L, Kim EJ ,Long J R (2021) Porous materials for carbon dioxide separations. Nat. Mater. 20: 1060-1072 https://doi.org/10.1038/s41563-021-01054-8

Singh AK (2008) R\&D Challenges for $\mathrm{CO}_{2}$ storage in coal seams. In: Goel M, Kuma, Charan SN (Eds) Carbon Capture and Storage: R\&D Technologies for Sustainable Energy Future. Narosa Publishing House, New Delhi, pp. 139-149. ISBN: 978-81-7319-944-8.

Singh A K, Hajra P N (2018) Coalbed Methane in India: Its Relevance and Current Status. In: (Eds) Coalbed Methane in India. Springer, Cham, pp. 1-19. ISBN 978-3-319-66465-1

Singh A K, Mohanty D(2014) $\mathrm{CO}_{2}$ Sequestration Potential of Indian Coalfields. In: Goel M, Sudhakar M, Shahi RV (Eds) Carbon Capture, Storage and, Utilization: A possible climate change solution for energy industry. TERI, New Delhi, pp 133-147. ISBN 780367179083. 
Singh A K, Mendhe VA, Garg A (2006) $\mathrm{CO}_{2}$ storage potential of geologic formations in India. In 8th Greenhouse Gas Technology Conference, Trondheim, Norway.

Singh U, Sharma N, Dunn J B (2021) Revisiting geologic storage potential in unconventional formations is key to proactive decision making on CCS in India. Front. Clim. 3: 708320. 10.3389/fclim.2021.708320

Smit B, Reimer JA, Oldenburg CM, Bourg IC (2014). Introduction to carbon capture and sequestration. Imperial College Press, London, pp 1-580.

Smith L J, Torn MS (2013). Ecological limits to terrestrial biological carbon dioxide removal. Climatic Change, 118, 89-103. https://doi.org/10.1007/s10584-012-0682-3

Smith M R, Myers S S(2018). Impact of anthropogenic CO2 emissions on global human nutrition. Nature Climate Change8: 834-839. https://doi.org/10.1038/s41558-018-0253-3

Snyder B F, Layne M, Dismukes D E (2020) A cash flow model of an integrated industrial CCSEOR project in a petrochemical corridor: A case study in Louisiana. International Journal of Greenhouse Gas Control 93: 102885. https://doi.org/10.1016/j.ijggc.2019.102885 
Sohngen B, Mendelsohn R. (2003) An optimal control model of forest

carbonsequestration. American Journal of Agricultural Economics 85(2): 448-

457.https://www.jstor.org/stable/1245140

Sonde R R. Demonstration of capture, injection, and geological Sequestration (storage) in Flood Basalt Formation of India. NTPC India.

https://www.cslforum.org/cslf/sites/default/files/documents/Basalt_Formation.pdf (Accessed 23Oct-2020)

Srivastava R P, Vedanti N, Akervoll I, Bergmo P, Yerramilli R C, YerramilliS S, Dimri V P (2015). Study of $\mathrm{CO}_{2}$ EOR in a Sector Model from Mature Oil Field, Cambay Basin, India. Petroleum Geosciences: Indian Contexts, 87-98. doi:10.1007/978-3-319-03119-4_3

Street JH, Paytan A (2005) Iron, phytoplankton growth, and the carbon cycle. Met Ions BiolSyst, 43, 153-93.doi: 10.1201/9780824751999.ch7

Subbarao P M V, Kapoor R, Vijay VK (2018). Capture of CO2 from biogas and production of industry worthy $\mathrm{CO} 2$ and compressed biomethane. Workshop on Awareness and Capacity Building in Carbon Capture and Storage and Utilization. GOI. pp. 12-13

Tambaria T N, Sugai Y, Nguele R (2022) Adsorption Factors in Enhanced Coal Bed Methane Recovery: A Review. Gases2(1): 1-21. https://doi.org/10.3390/gases2010001 
Tanushree Chandra (2021) Pricing carbon: Trade-offs and opportunities for India. Observer Research Foundation. https://www.orfonline.org/expert-speak/pricing-carbon-trade-offsopportunities-india/\# edn5 (Accessed 06 September 2021)

TERI (2013). India CCS Scoping Study: Final Report. New Delhi: The Energy and Resources Institute. 42pp. [Project Report No. 2011BE02]

ThibeauS, Mucha V (2011) Have we overestimated saline aquifer $\mathrm{CO}_{2}$ storage capacities? Oil \& Gas Science and Technology-Revue d'IFP Energies nouvelles, 66(1), 81-92. https://doi.org/10.2516/ogst/2011004

Thomas D M, Mechery J, Paulose S V (2016) Carbon dioxide capture strategies from flue gas using microalgae: a review. Environ Sci Pollut Res 23: 16926-16940. https://doi.org/10.1007/s11356-016-7158-3

Thorne S, La Rovere E L (1999) Criteria and indicators for appraising clean development mechanism (CDM) projects. Helio International. http://antigo.centroclima.coppe.ufrj.br/new2/ccpdf/CDM_Appraisal.PDF (Accessed on 14-Sept2021) 
Tiwari A K (2011). Energy consumption, CO2 emissions and economic growth: Evidence from India. Journal of International Business and Economy, 12(1), 85-122.

DOI:10.51240/jibe.2011.1.5

Tong X et al. (2020) Forest management in southern China generates short term extensive carbon sequestration. Nature Communications 11(1), 1-10. https://doi.org/10.1038/s41467-019$\underline{13798-8}$

Tripathi A D, Mishra R, Maurya K K,Singh R B, Wilson D W (2019) Estimates for World Population and Global Food Availability for Global Health. In: Singh RB, Eatson RR, Takahashi T. (Eds) The Role of Functional Food Security in Global Health. . Academic Press, London, pp. 3-24. ISBN: 978-0-12-813148-0.

Tripathi BC (2018). Climate Resilient Agriculture: Adaptation of Rice Plants to Elevated CO2 Grown in Free Air Carbon Dioxide Enrichment (FACE) Facility. Workshop on Awareness and Capacity Building in Carbon Capture and Storage and Utilization, GOI, pp. 30.

Tsang C F, Niemi A(2017) Overview of Processes Occurring During CO 2 Geological Storage and Their Relevance to Key Questions of Performance. In Geological Storage of CO2 in Deep Saline Formations. Springer, Dordrecht, pp. 15-38. ISBN 978-94-024-0996-3 
Turley J, Blackford J, Hardman-Mountford NJ, Litt E, Llewellyn CA, Miller PI, Nightingale PD, Rees AP, Smyth T, Tilstone G, Widdicombe S (2010). Carbon Uptake, Transport and Storage by Oceans and the Consequences of Change. In Hester R, Harrison R (Eds) Carbon Capture: Sequestration and Storage. Royal Society of Chemistry, Great Britain, pp 240-284. ISBN 978-1-84755-917-3.

Mishra T (2020) Renewable purchase obligation compliance remains low in most States. The Hindu Business Line. https://www.thehindubusinessline.com/economy/renewable-purchaseobligation-compliance-remains-low-in-most-states/article32002527.ece (Accessed 06-Sept2021)

UNEP (2005). The Clean Development Mechanism (CDM). Collaborating Centre on Energy and Environment Risø National Laboratory, Roskilde, Denmark.

UNFCCC (2011). Synthesis of views on modalities and procedures for carbon dioxide capture and storage in geological formations as clean development mechanism project activities. Durban: UNFCCC.

United Nations (2019). United Nations world population prospects. United Nations. IRL: https://population.un.org/wpp/ (Accessed on 13-Sept-2021) 
United Nations Environment Programme (2017). The Emissions Gap Report 2017. United

Nations Environment Programme, Nairobi. URL: https://www.unep.org/resources/emissionsgap-report-2017 (Accessed on 13-Sept-2021)

United Nations Environment Programme (2018). The Emissions Gap Report 2018. United Nations Environment Programme, Nairobi. URL: https://www.unep.org/resources/emissionsgap-report-2018 (Accessed on 12-Sept-2021)

United Nations Environment Programme (2019). Emissions Gap Report 2019. United Nations Environment Programme, Nairobi.

United Nations Environment Programme (2020). Emissions Gap Report 2020. United Nations Environment Programme, Nairobi.

UNEPOS (1987) Montreal protocol on substances that deplete the ozone layer. Washington, DC: US Government Printing Office 26:128-136.

UNFCC (2021a). The Doha Amendment. https://unfccc.int/process/the-kyoto-protocol/the-dohaamendment. (Accessed 14-Sept-2021).

UNFCC (2021b). What is the Kyoto Protocol? https://unfccc.int/kyoto_protocol (Accessed on $\underline{14-S e p t-2021}$ 
US Chamber of Commerce. (2012). CO2 Enhanced Oil Recovery. US Chamber of Commerce Vale M A, Ferreira A, Pires J C,Gonçalves A L(2020) CO2 capture using microalgae. In: Mohammad Reza Rahimpour, Mohammad Farsi, Mohammad Amin Makarem (Eds) In Advances in Carbon Capture. Woodhead Publishing, Duxford, pp 381 - 405. ISBN 9780128196571

van der MeerLGH, Yavuz F. (2009) CO2 storage capacity calculations for the Dutch subsurface. Energy Procedia1(1): 2615-2622. doi:10.1016/j.egypro.2009.02.028

Vangkilde-PedersenT, et al (2009)Assessing European capacity for geological storage of carbon dioxide-the EU Geo Capacity project. Energy Procedia 1(1): 2663 2670. doi: 10.1016/j.egypro.2009.02.034

Vasco DW, Dixon T H, Ferretti A, Samsonov S V (2020). Monitoring the fate of injected CO2 using geodetic techniques. The Leading Edge 39(1): 29-37. https://doi.org/10.1190/tle39010029.1

Vedanti N, Sen M K (2009) Seismic inversion tracks in situ combustion: A case study from Balol oil field, India. Geophysics 74(4): B103-B112. doi:10.1190/1.3129262

Verma M, Palacios J, Pélletier F, Godbout S, Brar S K, Tyagi R D, Surampalli R Y (2015). Carbon Capture and Sequestration: Physical/Chemical Technologies. In Surampalli R Y, Zhnag T C, Tyagi R D, Naidu R, Gurjar B R, Ojha C S P, Yan S, Brar S K, Ramakrishnan A, Kao C 
M. (Eds.) Carbon Capture and Storage: Physical, Chemical, and Biological Methods. American Society of Civil Engineers, Viriginia, pp 37-64. ISBN 978-0-7844-7891-2

Verma V S (2021) Challenges for $\mathrm{CO}_{2}$ Management Through Renewable Energy, Conventional Power and System Reliability in Indian Power Sector. In: Goel M, Satyanarayana T, Sudhakar M, Agrawal DP. (Eds.) Climate Change and green chemistry of $\mathrm{CO}_{2}$ sequestration. Springer, Singapore, pp 47-55. ISBN: 978-981-16-0028-9.

Viebahn P, Vallentin D, Höller S (2014) Prospects of carbon capture and storage (CCS) in India's power sector-An integrated assessment. Applied Energy 117: 62-75. https://doi.org/10.1016/j.apenergy.2013.11.054

Vishal V (2017a) In-situ disposal of CO2: Liquid and supercritical $\mathrm{CO}_{2}$ permeability in coal at multiple down-hole stress conditions. Journal of CO2 Utilization17: 235-

242.https://doi.org/10.1016/j.jcou.2016.12.011

Vishal V (2017b) Saturation time dependency of liquid and supercritical $\mathrm{CO}_{2}$ permeability of bituminous coals: Implications for carbon storage. Fuel192: 201-

207.https://doi.org/10.1016/j.fuel.2016.12.017 
Vishal V, Mahanta B, Pradhan S P, Singh T N, Ranjith P G (2018) Simulation of $\mathrm{CO}_{2}$ enhanced coalbed methane recovery in Jharia coalfields, India. Energy 159: 1185-1194.

https://doi.org/10.1016/j.energy.2018.06.104

Vishal V, Singh T N, Ranjith P G (2012) Carbon capture and storage in Indian coal seams.

In Carbon Management Technology Conference. Carbon Management Technology Conference.

Doi: $\underline{10.7122 / 151614-M S}$

Vishal V, Ranjith PG, Singh T N (2013) $\mathrm{CO}_{2}$ permeability of Indian bituminous coals:

Implications for carbon sequestration. International Journal of Coal Geology 105: 3647. doi:10.1016/j.coal.2012.11.003

VishalV, Singh L, Pradhan S P, Singh T N, Ranjith P G(2013)Numerical modelling of Gondwana coal seams in India as coalbed methane reservoirs substituted for carbon dioxide sequestration. Energy 49: 384-394. doi:10.1016/j.energy.2012.09.045

Vishal V, Chandra D, Singh U, Verma Y (2021) Understanding initial opportunities and key challenges for CCUS deployment in India at scale. Resources, Conservation and Recycling 175: 105829. https://doi.org/10.1016/j.resconrec.2021.105829

Vishal V, Verma Y, Chandra D, Ashok D (2021). A systematic capacity assessment and classification of geologic $\mathrm{CO}_{2}$ storage systems in India. International Journal of Greenhouse Gas Control 111:103458. https://doi.org/10.1016/j.ijggc.2021.103458 
Viswanaathan S, Perumal P K, Sundaram S (2022) Integrated Approach for Carbon

Sequestration and Wastewater Treatment Using Algal-Bacterial Consortia: Opportunities and Challenges. Sustainability14(3): 1075. https://doi.org/10.3390/su14031075

Viswanaathan S, Sudhakar M P (2019). Microalgae: potential agents for $\mathrm{CO}_{2}$ mitigation and bioremediation of wastewaters. In Singh J S (Ed) New and Future Developments in Microbial Biotechnology and Bioengineering. Elsevier, 129-148. doi:10.1016/b978-0-12-818258-1.00008$\mathrm{X}$

WaniAA, Joshi P K, Singh O, Pandey R (2012) Carbon Inventory Methods in Indian Forests-A Review. International Journal of Agriculture and Forestry 2(6): 315-323.doi: 10.5923/j.ijaf.20120206.09

WigleyTM L (1983) The pre-industrial carbon dioxide level. Climatic Change 5(4), 315-320. https://doi.org/10.1007/BF02423528

Wood (2020). What the three colours of hydrogen.https://spectra.mhi.com/what-are-the-threecolorsofhydrogen\#: :text=This $\% 20$ video $\% 20$ looks $\% 20$ at $\% 20$ the,the $\% 20$ air $\% 20$ as $\% 20$ they $\% 20$ combu st. (Accessed on 26-June-2021) 
World Bank (2020). India Carbon (CO2) Emissions 1960-2021.

https://www.macrotrends.net/countries/IND/india/carbon-co2-emissions Accessed on 2021-0523.

World Bank (2020). India GDP Growth Rate 1961-2021.

https://www.macrotrends.net/countries/IND/india/gdp-growth-rate Accessed on 2021-05-23.

Xavier C, Oliveira C(2021) Decarbonisation options for the Dutch cement industry. PBL Netherlands Environment Assessment agency, Hague.

Xie X, Economides M J (2009) The Impact of Carbon Geological Sequestration. SPE Americas E \& P Environmental and Safety Conference. Doi:10.2118/120333-ms

Yadav A, Choudhary P, Atri N, Teir S, Mutnuri S (2016) Pilot project at Hazira, India, for capture of carbon dioxide and its biofixation using microalgae. Environ Sci Pollut Res Int. 23, 22284-22291. doi: 10.1007/s11356-016-6479-6.

Yadav S, Mondal S S (2022) A review on the progress and prospects of oxy-fuel carbon capture and sequestration (CCS) technology. Fuel 308: 122057.

https://doi.org/10.1016/j.fuel.2021.122057

Yadava PS (2010) Soil and vegetation carbon pool and sequestration in the forest ecosystems of Manipur, NE India. In: Qasim SZ, Goel M. CO2 Sequestration Technologies for Clean 
Energy:Awareness and Capacity Building. Daya Publishing House, Delhi, pp.163-170 ISBN 817035-660-8.

Yadava PS, Thokchom A(2021)Effect of Anthropogenic Activities on the Rate of Soil CO 2 Flux in the Dipterocarpus Forest Ecosystem of Northeast India.In: Goel M, Satyanarayana T, Sudhakar M, Agrawal DP. (Eds.) Climate Change and green chemistry of $\mathrm{CO} 2$ sequestration. Springer, Singapore, pp 273 - 288. ISBN: 978-981-16-0028-9.

Yoro K O, Daramola M O (2020). $\mathrm{CO}_{2}$ emission sources, greenhouse gases, and the global warming effect. In: Mohammad Reza Rahimpour, Mohammad Farsi, Mohammad Amin Makarem (Eds) Advances in Carbon Capture. Woodhead Publishing, Duxford, pp 3-28. ISBN 9780128196571

Yuen YT, Sharratt PN, Jie B(2016) Carbon dioxide mineralization process design and evaluation: concepts, case studies, and considerations. Environ Sci Pollut Res 23: 22309-22330 (2016). https://doi.org/10.1007/s11356-016-6512-9

Zakharova N V, Goldberg D S, Olsen P E, Collins D, Kent D V(2020). Reservoir and sealing properties of the Newark rift basin formations: Implications for carbon sequestration. The Leading Edge 39(1): 38-46. doi:10.1190/tle39010038.1 
Zdravkov B D, Čermák J J,Šefara M, Janků J (2007) Pore classification in the characterization of porous materials: A perspective. Central European Journal of Chemistry 5:385-395. https://doi.org/10.2478/s11532-007-0017-9

Zeikus J G(1981) Lignin metabolism and the carbon cycle. In: Alexander M (Ed) Advances in Microbial Ecology. Volume 5. pp. 211-243. Springer, Boston. ISBN: 9780306407673.

Zevenhoven R, Fagerlund J(2009) CO2 fixation by mineral matter; the potential of different mineralization routes. IOP Conference Series: Earth and Environmental Science 6(17), 172008. https://doi.org/10.1088/1755-1307/6/17/172008

Zhang T, Zhang W, Yang R, Gao H, Cao D (2022) Analysis of Available Conditions for InSAR Surface Deformation Monitoring in CCS Projects. Energies15(2): 672. https://doi.org/10.3390/en15020672

Zhang T, Zhang W, Yang R, Liu Y, Jafari M (2021) CO2 capture and storage monitoring based on remote sensing techniques: A review. Journal of Cleaner Production281:124409. https://doi.org/10.1016/j.jclepro.2020.124409

Zhao S, Feron P H, Deng L, Favre E, Chabanon E, Yan S, Hou J, Chen V, Qi H (2016) Status and progress of membrane contactors in post-combustion carbon capture: A state-of-the-art review of new developments. Journal of Membrane Science 511: 180-206. https://doi.org/10.1016/j.memsci.2016.03.051 
Zomer R J, Trabucco A, Bossio D A, Verchot L V (2008) Climate change mitigation: A spatial analysis of global land suitability for clean development mechanism afforestation and reforestation. Agriculture, Ecosystems \&Environment 126(1-2): 67-80.

https://doi.org/10.1016/j.agee.2008.01.014 


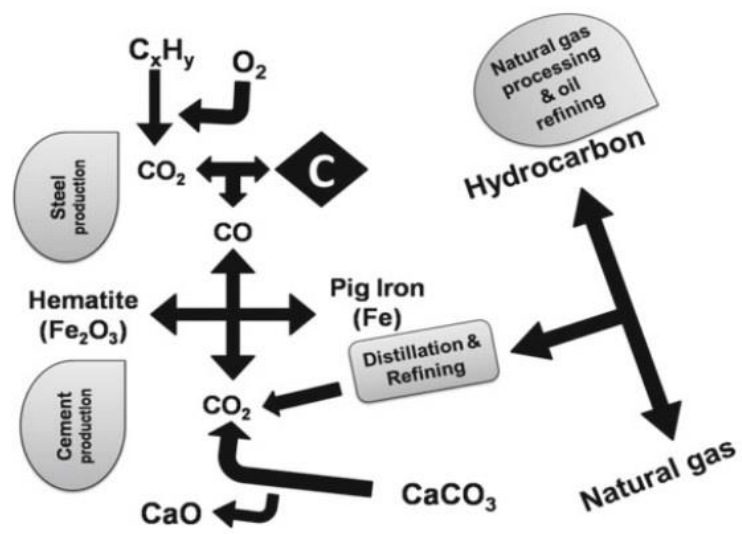

Fig. S1. An interactive diagram showing emission sources of hard-to-abate industries (Reproduced from fig 6.2 of Ahuja 2021)

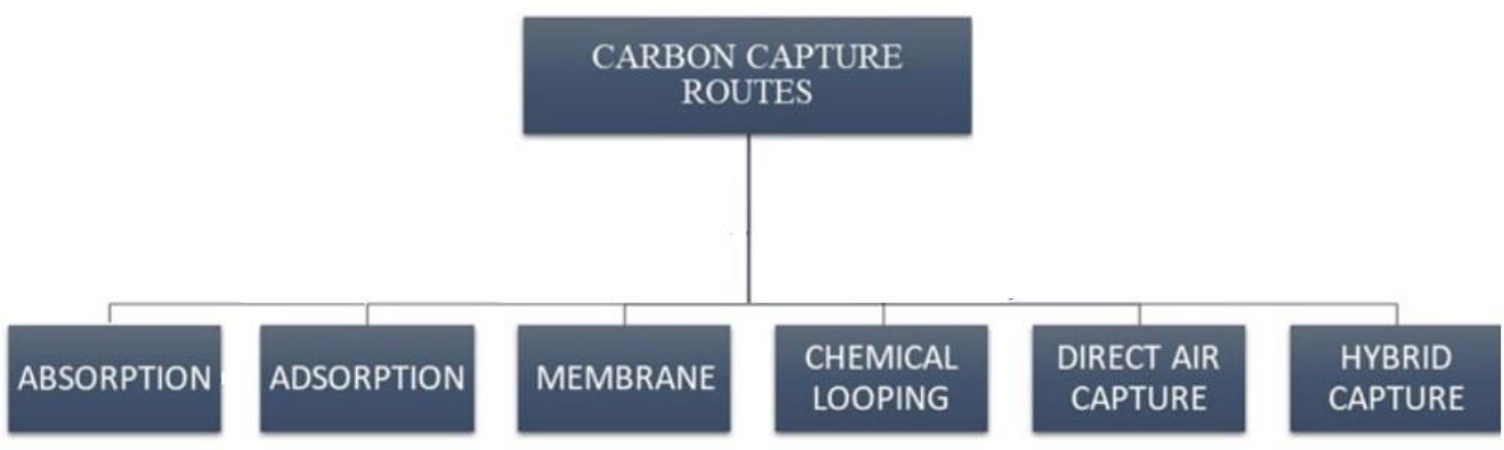

Fig. S2. Different methods of carbon capture (Modified from fig 2.1 of Khurana et al. 2021) 


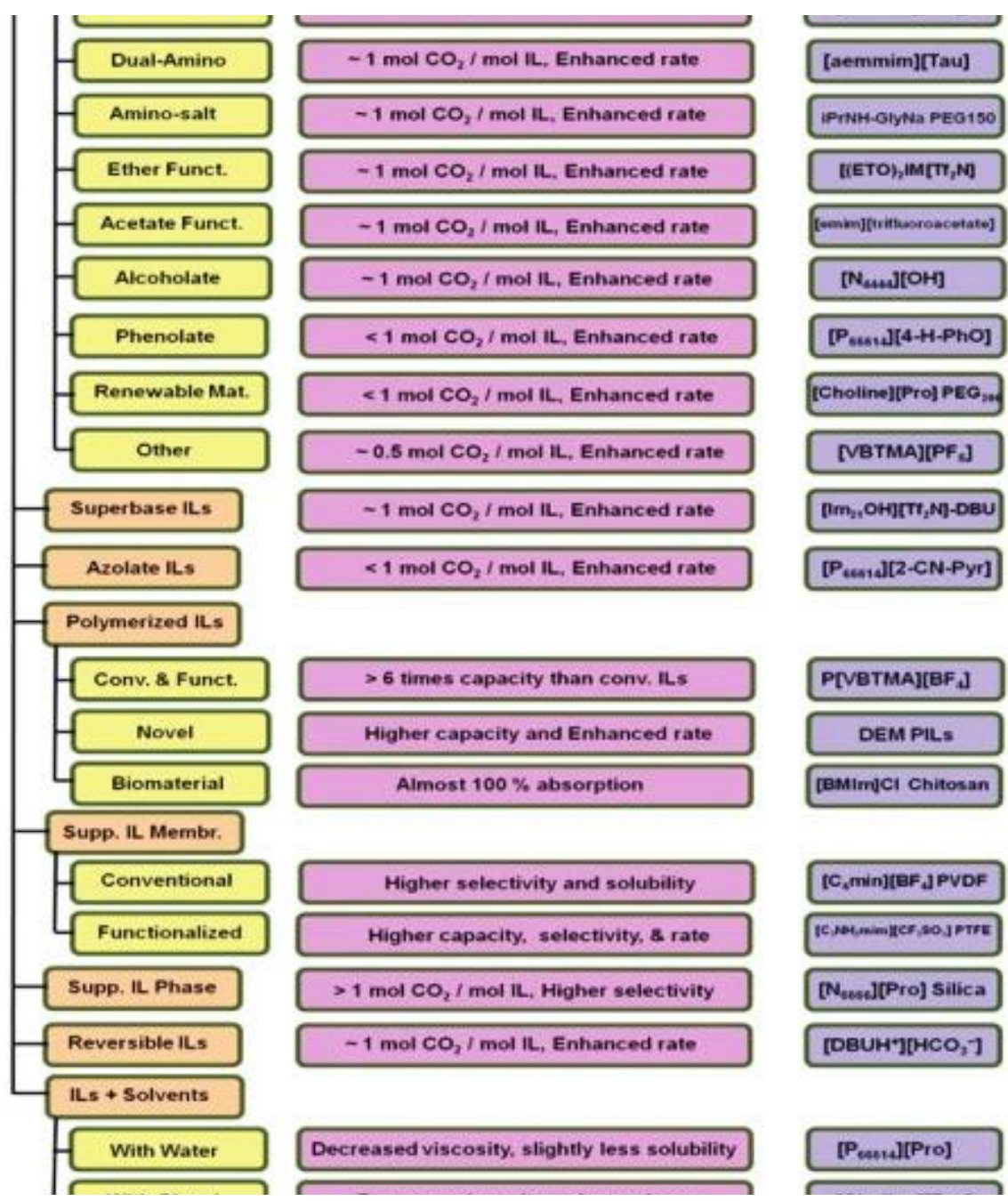

Fig. S3. A comprehensive list of various ionic liquids used in Post combustion capture (reproduced from figure 8.4 of Wasewar 2021). 


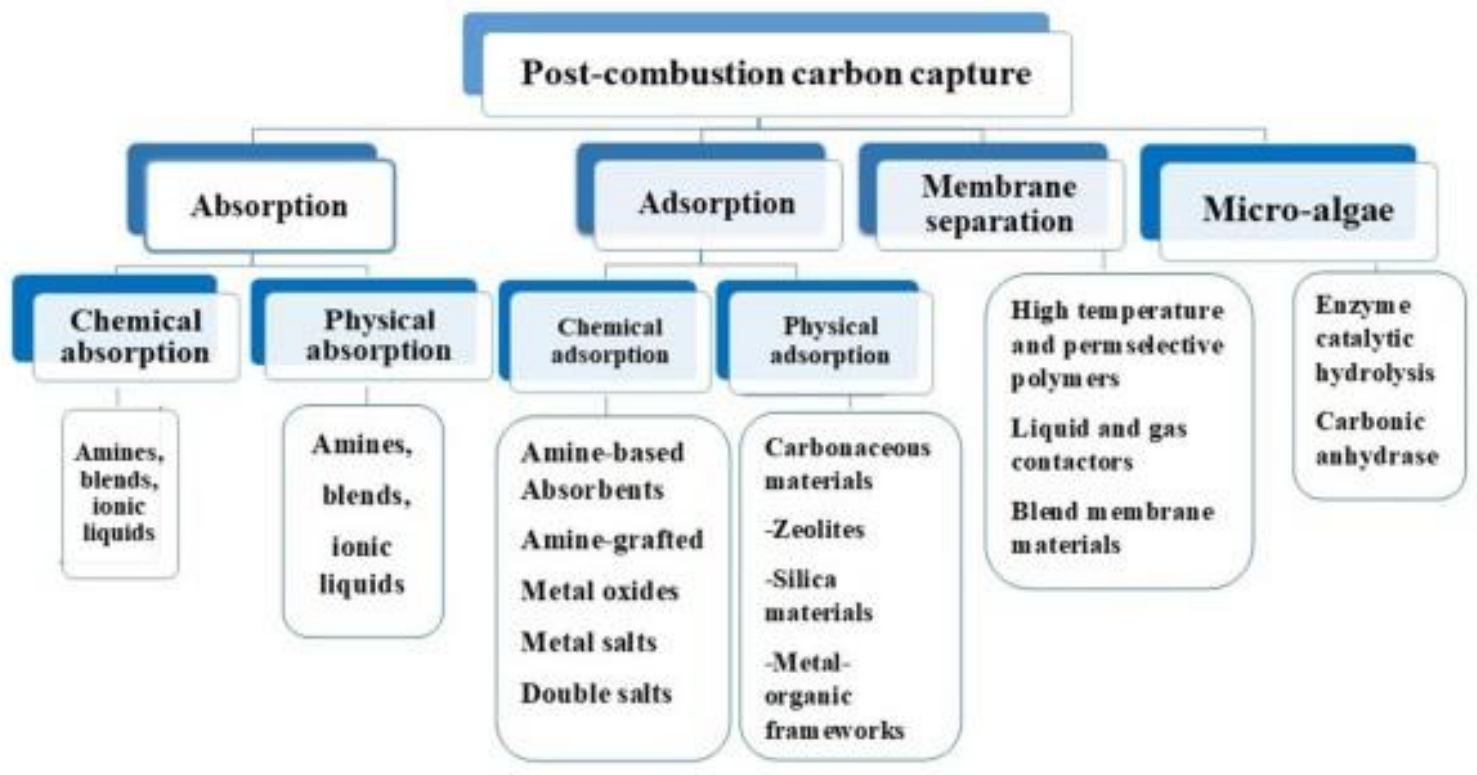

Fig. S4. A flowchart showing various methods of post combustion capture and different techniques under them (Reproduced from fig 4 of Osman et al. 2020)

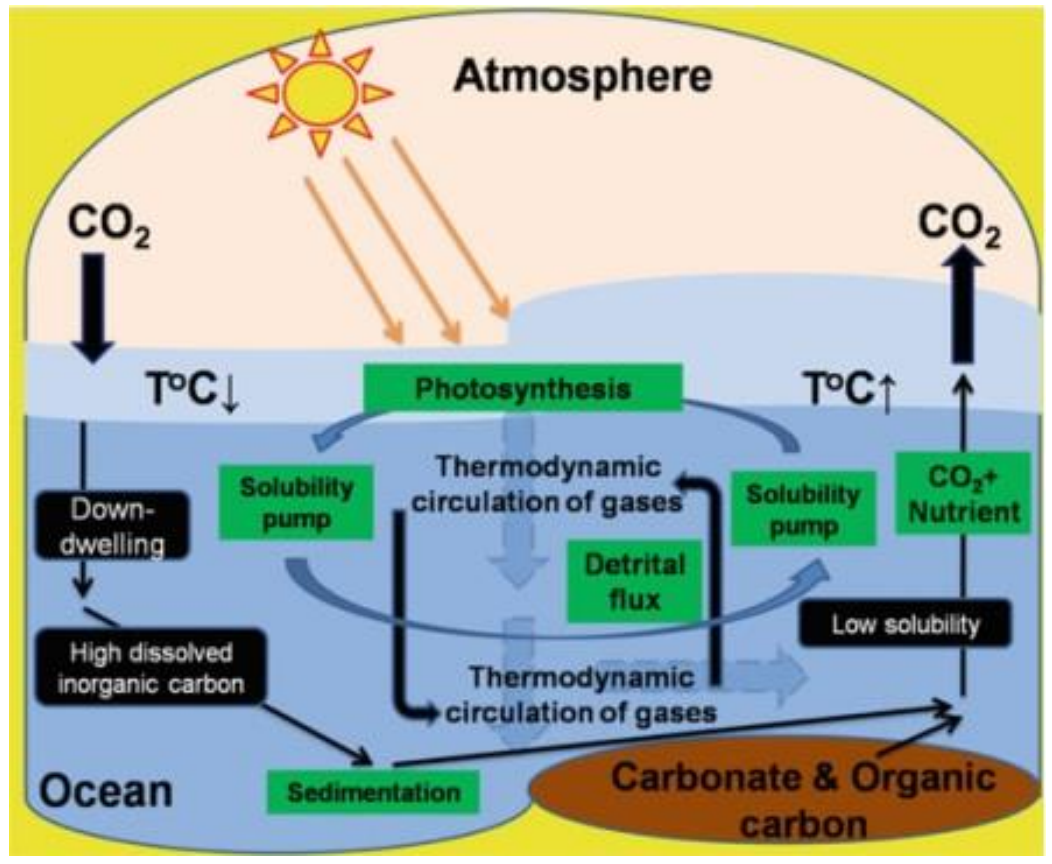

Fig. S5. Different carbon fluxes in an ocean (Reproduced from Ahuja 2021) 


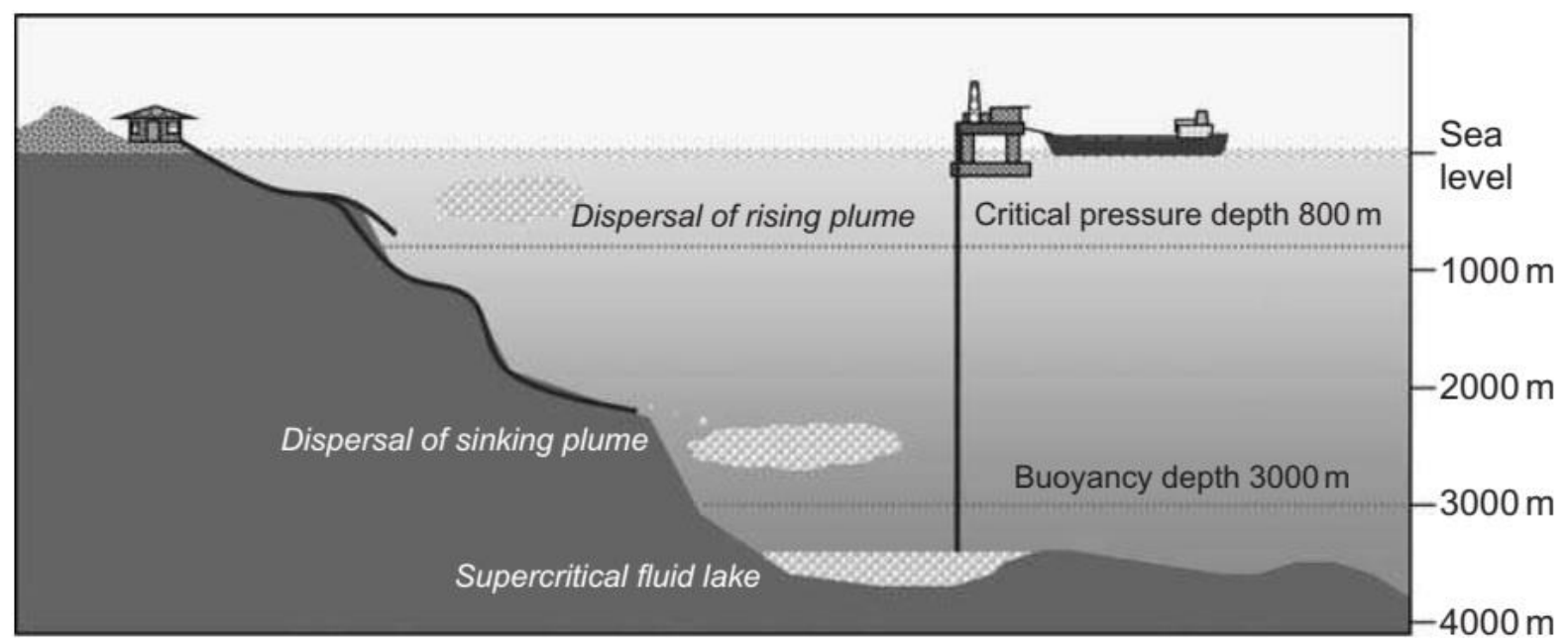

Fig. S6. Diagrammatic representation of oceanic abiotic sequestration at various depths (Reproduced from fig 2.4 of Rackley 2010)

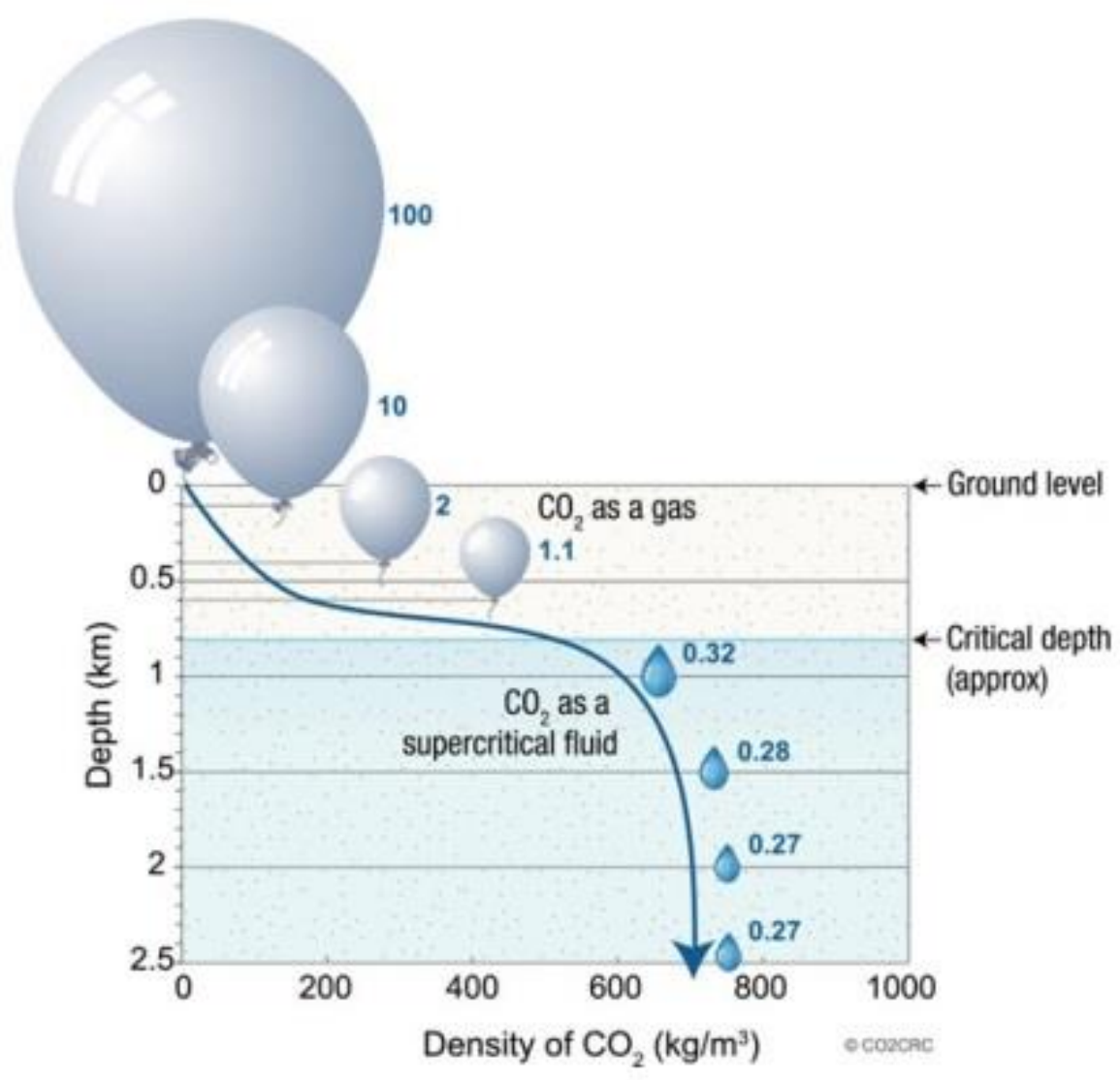

Fig. S7. Depth density diagram of Carbon dioxide (Reproduced from fig 2.1 of Ringrose 2020) 


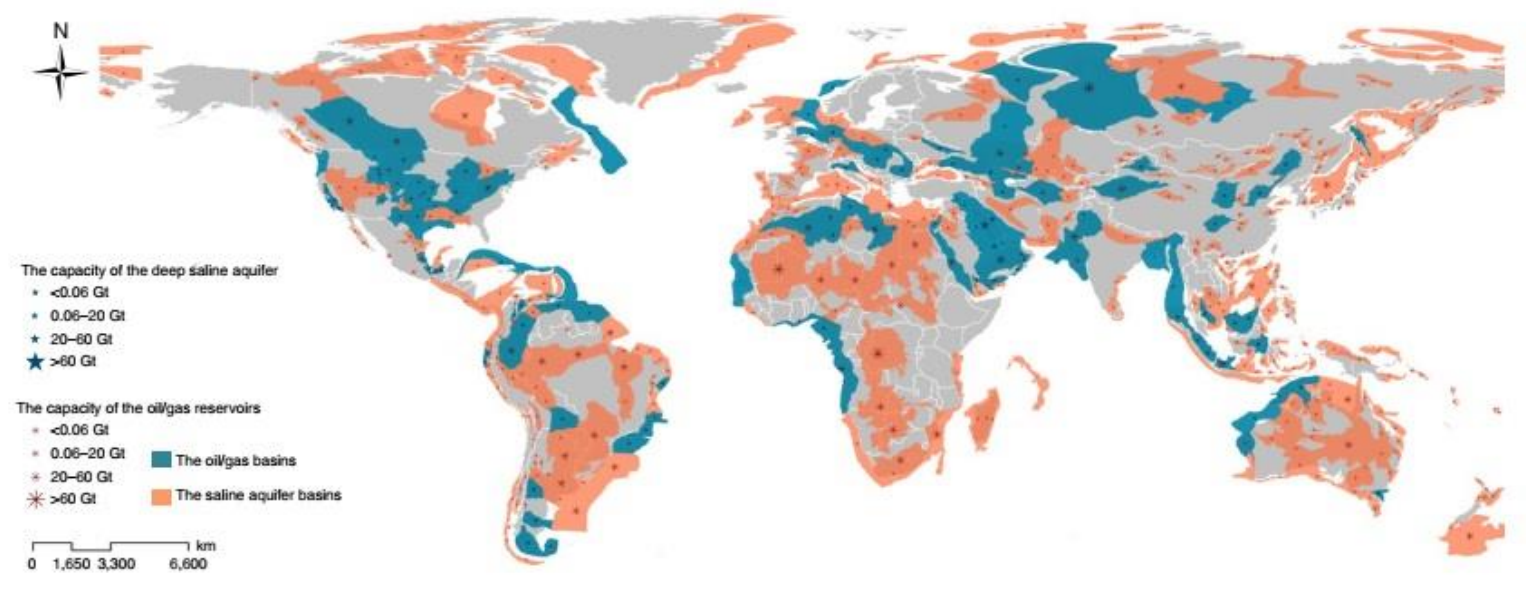

Fig. S8. World map showing sequestration capacity of deep saline aquifers (Reproduced from Fig 2a of Wei et al. 2021)

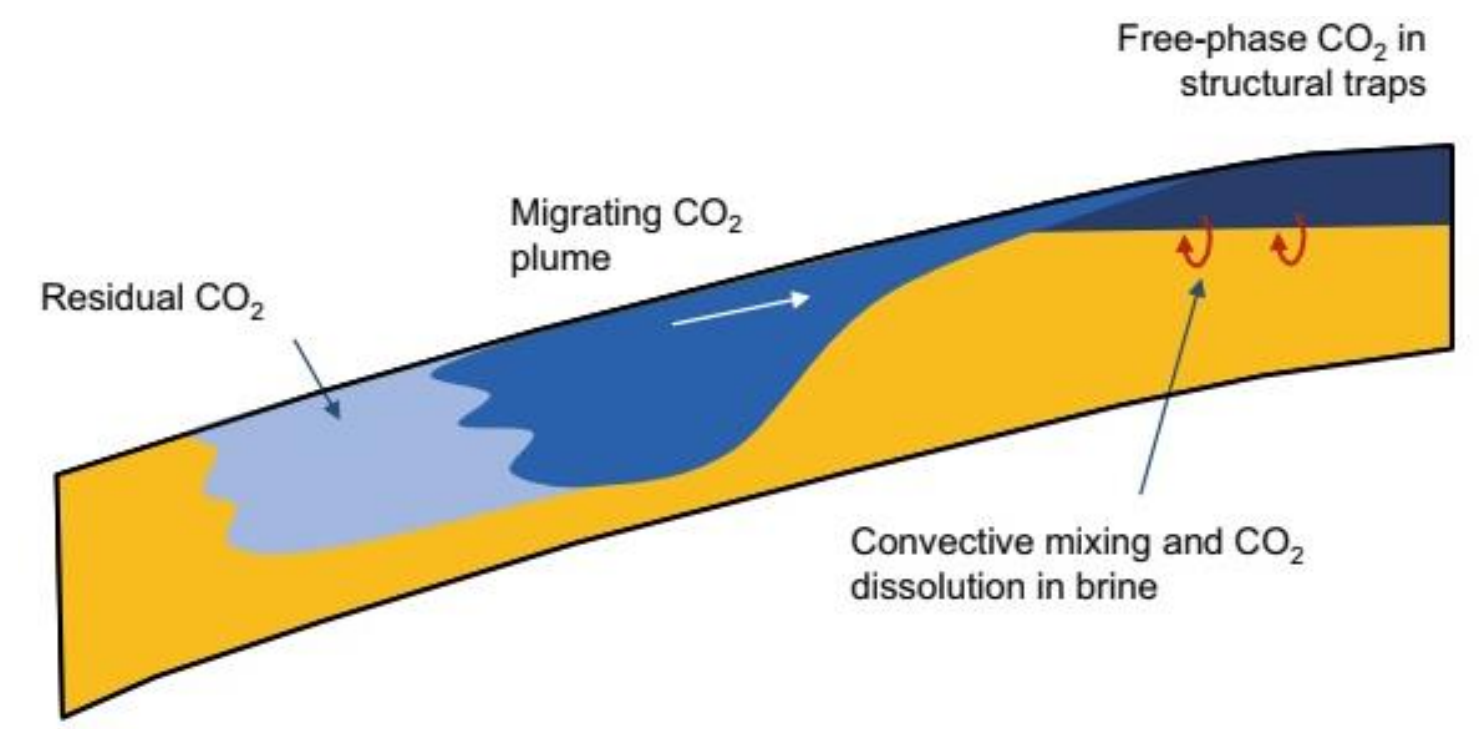

Fig. S9. $\mathrm{CO}_{2}$ storage mechanism is deep saline aquifers (Reproduced from fig 2.8 of Ringrose 2020) 


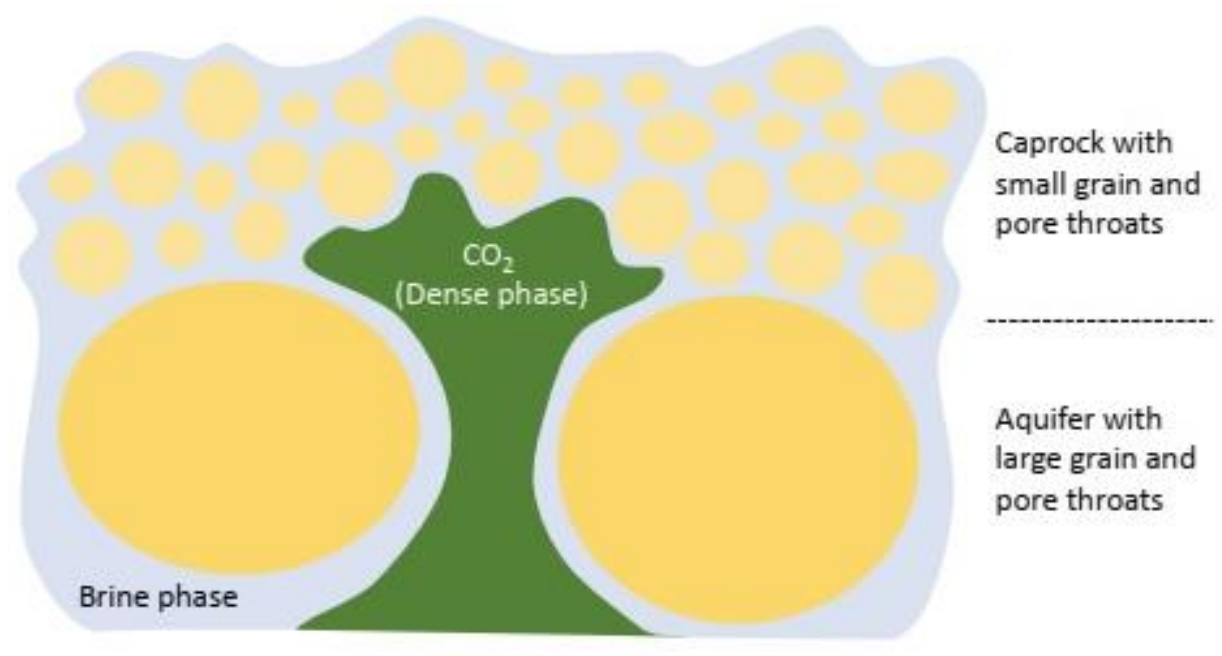

Fig. S10. A diagrammatic representation of capillary trapping mechanism during $C$ sequestration in deep saline aquifers (Reproduced from fig 2.6 of Ringrose 2020).

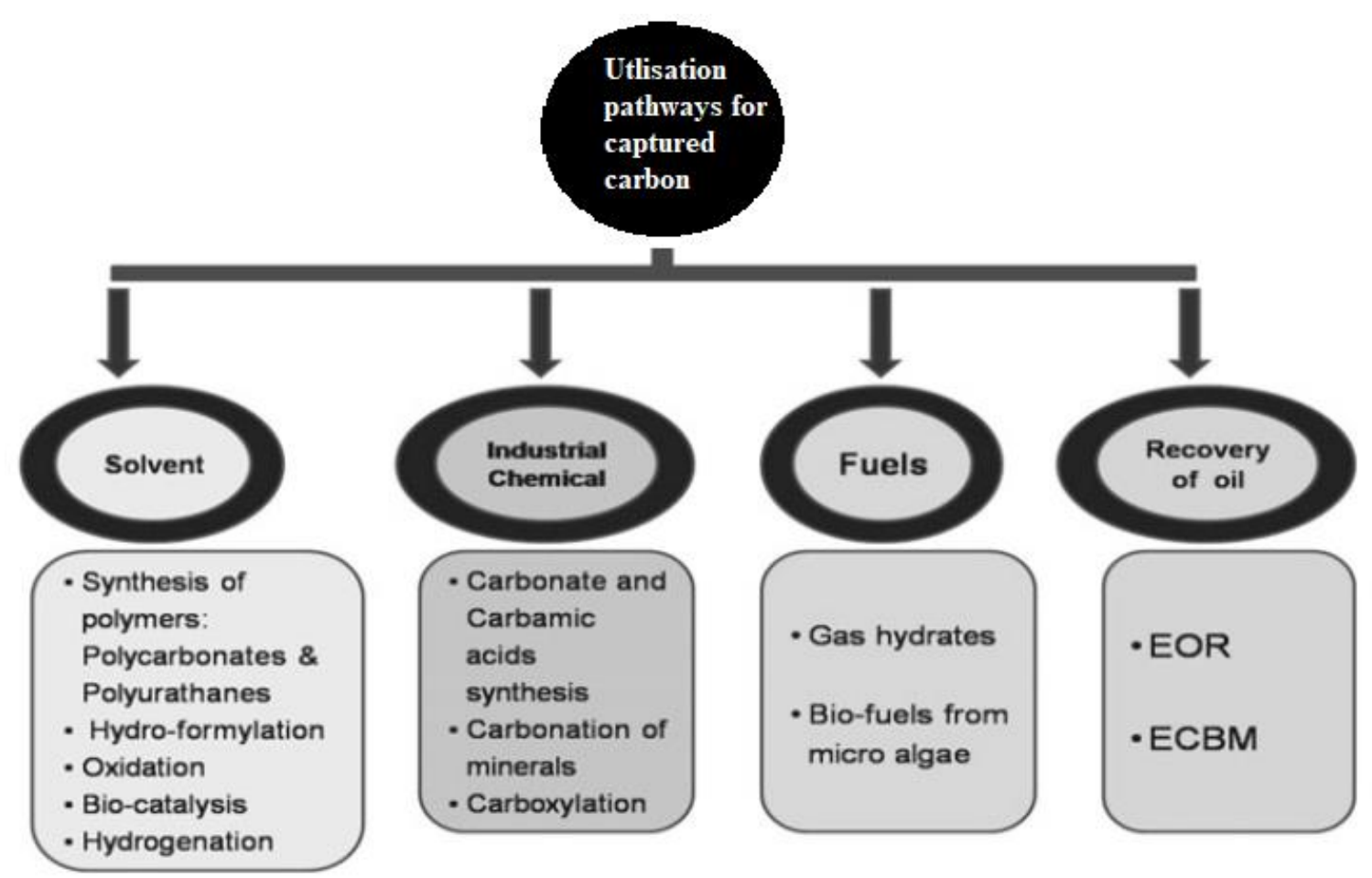

Fig. S11. Utilisation pathways of captured carbon (Modified from fig 6.14 of Ahuja 2021) 


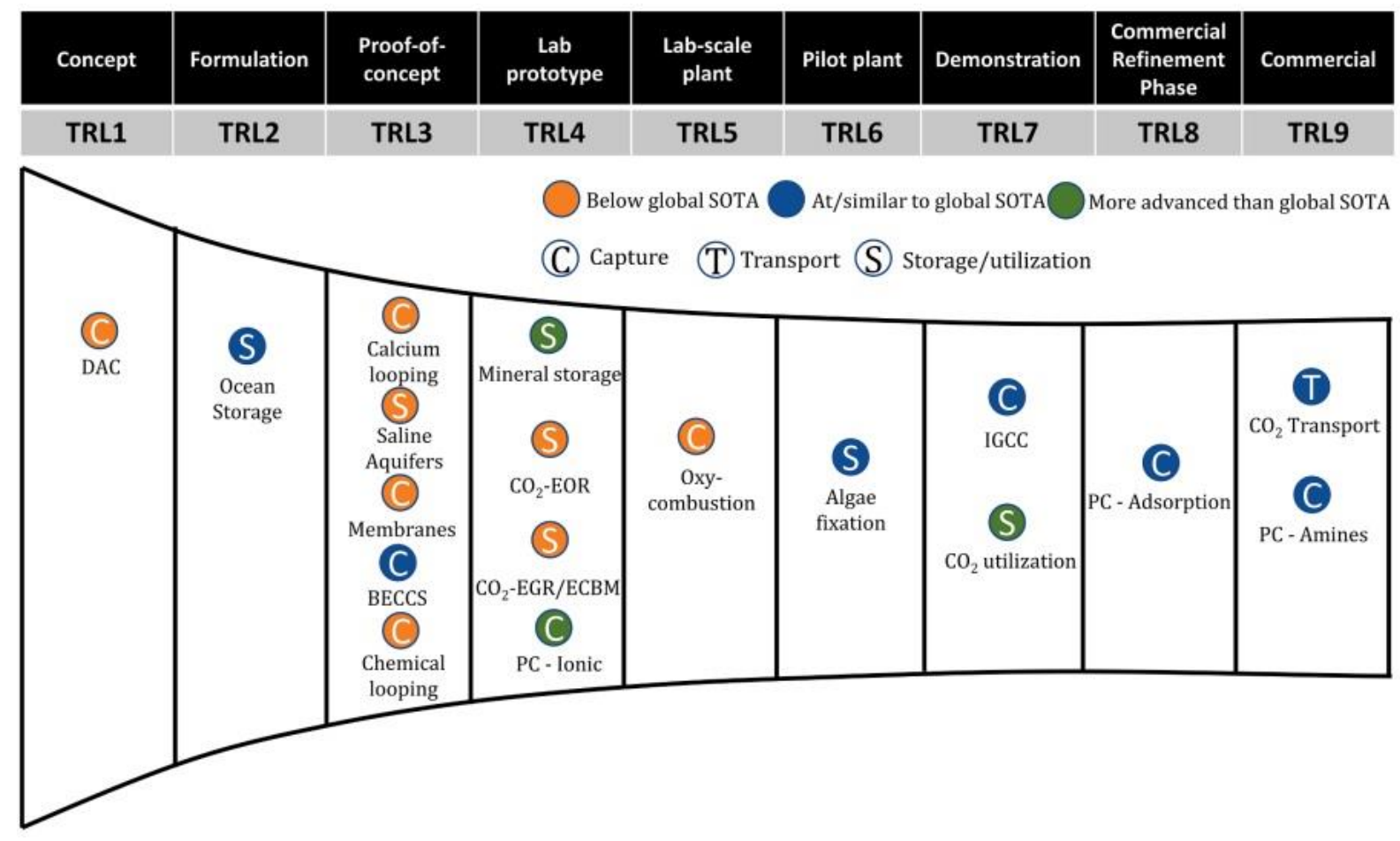

Fig S12. Technology readiness Level (TRLs) of various CCS technologies in India and their status in relation to their global state of the art equivalent (Reproduced from fig 9 of Vishal et al. 2021)

Table S1. Key climate agreements summarised.

\begin{tabular}{cccc}
\hline Name & Year & Key point & References \\
\hline Geneva convention & 1979 & $\begin{array}{c}\text { Creation of a regional framework } \\
\text { for reducing transboundary air } \\
\text { pollution. Contributed to decline in } \\
\end{array}$ & EP (2020) \\
& & air pollution &
\end{tabular}

Montreal protocol $1987 \quad$ Regulated the usage of 100 Ozone

UNEPOS (1987)

Depleting Substances (ODS). This

is the only treat that was ratified

by every country then. 
Kyoto protocol

Doha amendment made the countries commit to take substantial steps to reduce their greenhouse gas emissions.

Established the second commitment period of the Kyoto Protocol and came into effect on 31/12/2020. The participating countries shall decrease their emission level by $18 \%$, according to 1990 levels

Table S2. Advantages and disadvantages of other methods of reducing carbon emissions along with CCS (Modified from Khurana et al. 2021)

\begin{tabular}{|l|l|l|}
\hline Method & Advantages & Disadvantages \\
\hline $\begin{array}{l}\text { Use of cleaner fuels and } \\
\text { renewable energy }\end{array}$ & $\begin{array}{l}\text { Natural gas emits around 40- } \\
50 \% \text { less carbon dioxide and } \\
\text { efficiency isalso higher. } \\
\begin{array}{l}\text { Emissions are zero for } \\
\text { renewable energy. Significant } \\
\text { progress has been made in } \\
\text { Solar PV technologies. }\end{array}\end{array}$ & $\begin{array}{l}\text { High fuel cost and } \\
\text { infrastructural issues } \\
\text { entaining to renewable } \\
\text { energy sources }\end{array}$ \\
\hline Use of clean coal & Relatively Low emissions & Higher costs \\
\hline Nuclear Power & Zero emissions & $\begin{array}{l}\text { The usage is limited. Involves } \\
\text { impeccable maintenance. } \\
\text { Disasters like Fukushima } \\
\text { (Japan, 2011) and Chernobyl } \\
\text { (1986, Erstwhile USSR) tilt } \\
\text { the balance against it favour. }\end{array}$ \\
\hline
\end{tabular}




\begin{tabular}{|l|l|l|}
\hline Reforestation/afforestation & Natural approach. & $\begin{array}{l}\text { Requires land which is } \\
\text { already a strained resource. }\end{array}$ \\
\hline CCS & $\begin{array}{l}\text { Significant reduction in } \\
\text { emission. Considered a major } \\
\text { method in bringing down } \\
\text { emission levels and meeting } \\
\text { climate targets. }\end{array}$ & $\begin{array}{l}\text { Relatively higher cost } \\
\text { involved with research still } \\
\text { underway to establish validity } \\
\text { and feasibility of certain CCS } \\
\text { methods in the world. }\end{array}$ \\
\hline
\end{tabular}

Table S3. Carbon capture methods and their main properties (Modified from fig 6.1 of Ahuja 2021).

\begin{tabular}{|c|c|}
\hline Methods & Main properties \\
\hline \multicolumn{2}{|l|}{ ADSORBTION } \\
\hline Physical & $\begin{array}{l}\text { Occurs due to physical interaction between molecules and the adsorbtion material. The cost } \\
\text { of raw material is low }\end{array}$ \\
\hline Chemical & Similar to physical adsorption, except the adsorbtion material is chemical in nature. \\
\hline \multicolumn{2}{|l|}{ ABSORPTION } \\
\hline Physical & $\begin{array}{l}\text { Instead of chemical reaction with } \mathrm{CO}_{2} \text {, solvents are used to absorb it from the flue gas } \\
\text { stream }\end{array}$ \\
\hline Chemical & $\begin{array}{l}\text { As opposed to physical absorption, chemical solutions are used to absorb the } \mathrm{CO}_{2} \text { from the } \\
\text { flue gas }\end{array}$ \\
\hline \multicolumn{2}{|c|}{ CAPTURE THROUGH MEMBRANE SEPARATION } \\
\hline \multicolumn{2}{|c|}{$\begin{array}{l}\text { Depends on the permeability capacity of the membrane which further decides the cost and efficiency of the } \\
\text { membrane }\end{array}$} \\
\hline \multicolumn{2}{|c|}{ CRYOGENIC CAPTURE } \\
\hline \multicolumn{2}{|c|}{$\begin{array}{l}\text { This is a recent method that need } \sim 1 / 3^{\text {rd }} \text { energy and cost in relation to other capture processes. The basic } \\
\text { principle is that lowering the temperature of } \mathrm{CO}_{2} \text {-laden flue gas stream to }\left(-100 \text { to }-135^{\circ} \mathrm{C}\right) \text { separates the } \\
\text { solidified } \mathrm{CO}_{2} \text { from other gases in the flue gas. It is observed to have high efficiency in removing the pollutants } \\
\text { such as NOx, SOx etc. }\end{array}$} \\
\hline \multicolumn{2}{|c|}{ MINERAL CARBONATION } \\
\hline \multicolumn{2}{|c|}{$\begin{array}{l}\text { It's also mimicked naturally as a form of chemical weathering where } \mathrm{CO}_{2} \text { is locked away naturally in the form } \\
\text { of stable carbonated. The process however is incredibly slow and currently research is underway to recreate } \\
\text { and hasten the process in laboratories. }\end{array}$} \\
\hline
\end{tabular}


Table S4. Various microalgal species and their corresponding bioproducts (Compiled from table 6.2 of Ahuja 2021)

\begin{tabular}{|l|l|}
\hline Microalgal species & Products \\
\hline Chlorella vulgaris & Biodiesel \\
\hline Diplosphaerasp. MM1 & Biogas/Biomethane \\
\hline N. oculataand T. suecica & Bioethanol \\
\hline Haematococcuspluvialis & Astaxanthin \\
\hline Neochloris aquatica CL-M1 & Biobutanol \\
\hline
\end{tabular}

Table S5.Carbon sequestration scenarios of different LULC classes across Western Himalayas (Reproduced from table 12.2 of Rawat et al. 2021)

\begin{tabular}{|c|c|c|c|}
\hline $\begin{array}{l}\text { S. } \\
\text { No. }\end{array}$ & Study area & LULC classes & Findings \\
\hline 1 & $\begin{array}{l}\text { Kullu } \\
\text { (Himachal } \\
\text { Pradesh) }\end{array}$ & $\begin{array}{ll}\text { - } & \text { (agro)horticulture, } \\
\text { - } & \text { Agriculture; and } \\
\text { - } & \text { silvipasture }\end{array}$ & $\begin{array}{l}\text { Biomass accumulation trend } \\
\text { (lowest to highest): agriculture, } \\
\text { horticulture, agrohorticulture, } \\
\text { silvipasture, forest. } \\
\text { Rate of sequestration was highest } \\
\text { in agrohorticulture. }\end{array}$ \\
\hline 2 & $\begin{array}{l}\text { Solan } \\
\text { (Himachal } \\
\text { Pradesh) }\end{array}$ & Plantation & $\begin{array}{l}\text { Total sequestration (lowest to highest): } \\
\text { - } \quad \text { UlnusVillosa } \\
\text { - Albizia procera } \\
\text { - } \text { Quercus } \\
\text { - } \text { Pinus roxburghii } \\
\text { - Alnus nitida } \\
\text { - Acacia catechu } \\
\text { - } \text { Acacia mollissina } \\
\end{array}$ \\
\hline 3 & $\begin{array}{l}\text { Kwalkhad } \\
\text { watershed } \\
\text { (Himachal } \\
\text { Pradesh) }\end{array}$ & $\begin{array}{l}\text { - } \quad \text { Agrihortisilviculture, } \\
\text { - } \quad \text { agrisilvihorticulture, } \\
\text { - } \text { grassland, } \\
\text { - } \text { silvipasture, } \\
\text { - } \text { agrisilviculture, } \\
\text { - } \text { agriculture; and } \\
\text { - } \text { agrihorticulture } \\
\end{array}$ & $\begin{array}{l}\text { Carbon mitigation value (lowest to } \\
\text { highest): } \\
\text { - Agrihortisilviculture } \\
\text { - } \quad \text { Silvipasture } \\
\text { - Agrisilviculture } \\
\text { - } \text { Agrihorticulture }\end{array}$ \\
\hline 4 & $\begin{array}{l}\text { Experimental farm, } \\
\text { Vivekananda } \\
\text { Institute of Hill } \\
\text { Agriculture,Almora } \\
\text { (Uttarakhand) }\end{array}$ & $\begin{array}{ll}\text { - } & \text { Agroforesty } \\
\text { - } & \text { Cropland }\end{array}$ & $\begin{array}{l}\text { Pecan nut with crops stores more } \\
\text { carbon than crops alone. }\end{array}$ \\
\hline
\end{tabular}




\begin{tabular}{|c|c|c|c|}
\hline 5 & $\begin{array}{l}\text { Bilaspur, Kangra, } \\
\text { Una, Hamirpur } \\
\text { Solan ,Sirmaur } \\
\text { (Himachal } \\
\text { Pradesh) }\end{array}$ & $\begin{array}{ll}\text { - } & \text { Agriculture, } \\
\text { - } & \text { horticulture, } \\
\text { - } & \text { agrisilvicultural, } \\
\text { - } & \text { silvopastoral, } \\
\text { - } & \text { agrihorticulture, } \\
\text { - } & \text { agrihortisilviculture, } \\
\text { - } & \text { forest; and } \\
\text { grassland }\end{array}$ & $\begin{array}{l}\text { - Forest exhibited highest carbon } \\
\text { stock. } \\
\text { Agrihortisilviculture exhibited highest } \\
\text { carbon stock. }\end{array}$ \\
\hline 6 & $\begin{array}{l}\text { Garhwal region } \\
\text { (Uttarakhand) }\end{array}$ & $\begin{array}{l}\text { Six different forest types } \\
\text { 1.Abies spectabilis, } \\
\text { 2.Cedrus deodara, } \\
\text { 3.Pinus wallichiana, } \\
\text { 4.Quercus floribunda, } \\
\text { 5.Quercus leucotrichophora; } \\
\text { 6.Quercus semecarpifolia }\end{array}$ & $\begin{array}{l}\text { BGB stock in Abies pindrow } \\
\text { forests exhibited maximum C } \\
\text { assimilation capacity. } \\
\text { Cedrus deodara forests exhibited least } \\
\text { BGB stock }\end{array}$ \\
\hline 7 & $\begin{array}{l}\text { Kumaun region, } \\
\text { (Uttarakhand) }\end{array}$ & $\begin{array}{l}\text { - Quercus leucotrichophora } \\
\text { Forest }\end{array}$ & Banj Oak has maximum C stock \\
\hline 8 & $\begin{array}{l}\text { Kupwara( } \\
\text { Jammu \& } \\
\text { Kashmir) }\end{array}$ & Agroforestry & $\begin{array}{l}\text { It was estimated the agroforestry } \\
\text { systems in Kupwara district } \\
\text { completely offset the GHG emissions } \\
\text { from the agriculture sector. }\end{array}$ \\
\hline 9 & $\begin{array}{l}\text { Nainital } \\
\text { (Uttarakhand) }\end{array}$ & Agrihorticulture (mango-based) & $\begin{array}{l}\text { The combination of mango and wheat } \\
\text { cropping pattern have sequestered } \\
\text { more } \mathrm{C} \text { that mango-black soyabean } \\
\text { combination and single cropping } \\
\text { system }\end{array}$ \\
\hline
\end{tabular}


Table S6. Carbon sequestration scenarios of different soil types across Western Himalayas (Reproduced from table 12.3 of Rawat et al. 2021)

\begin{tabular}{|l|l|l|}
\hline Sr. No. & Study area & Findings \\
\hline 1 & Southern part of J\&K & $\begin{array}{l}\text { SOC's CO2 mitigation density in t ha-1 was } \\
\text { highest in Abies pindrow-Piceasmithiana } \\
\text { occupied soils and lowest in Cedrus deodara } \\
\text { occupied soils. }\end{array}$ \\
\hline 2 & Kullu (Himachal Pradesh) & $\begin{array}{l}\text { Carbon density in 0-100 cm soil layer } \\
\text { highest in agrihorticulture } \\
\text { lowest in the barren land }\end{array}$ \\
\hline 3 & $\begin{array}{l}\text { Pahalgam\& Anantnag (Jammu \& } \\
\text { Kashmir) }\end{array}$ & $\begin{array}{l}\text { Highest SOC stock exhibited by soils occupied } \\
\text { by Pinus wallichiana forest }\end{array}$ \\
\hline 5 & $\begin{array}{l}\text { SOC stocks } \\
\text { found to be higher in soil occupied by forest } \\
\text { and pastures than those occupied by } \\
\text { agriculture. } \\
\text { found highest in temperate forest followed by } \\
\text { lower alpine forest, upper alpine forest and } \\
\text { subtropical. }\end{array}$ \\
\hline 6 & Himalayan foothills of J\&K & $\begin{array}{l}\text { Forest covered lands exhibited 25\% more SOC } \\
\text { than agricultural and degraded land. This } \\
\text { shows that the conversion of land for } \\
\text { agricultural uses is leading to an estimated 12.4 } \\
\text { Mg ha- 1 of SOC losses. }\end{array}$ \\
\hline Carbon management Index (CMI) was highest \\
\hline
\end{tabular}




\begin{tabular}{|l|l|l|}
\hline \multirow{2}{*}{} & & $\begin{array}{l}\text { in soils under forest followed by organic } \\
\text { farming, soya bean, wheat (for fodder) and } \\
\text { barren land. } \\
\text { The labile C value was highest in soils under } \\
\text { forest followed by organic farming, soyabean } \\
\text { (fodder), wheat and barren land. }\end{array}$ \\
\hline 7 & Almora (Uttarakhand) & $\begin{array}{l}\text { Oak forest exhibited greater C stock than pine } \\
\text { forests. }\end{array}$ \\
\hline
\end{tabular}

Table S7. A compilation of various studies estimating sequestration potential of various terrestrial systems.

\begin{tabular}{|c|c|c|c|l|c|}
\hline Serial No. & Study area & Methodology & $\begin{array}{c}\text { Sequestered } \\
\text { potential } \\
\text { (T/ha/year) }\end{array}$ & $\begin{array}{l}\text { Additional } \\
\text { remarks }\end{array}$ & Reference \\
\hline 1 & Mizoram & $\begin{array}{c}\text { tree allometric } \\
\text { equations }\end{array}$ & 21.575 & $\begin{array}{l}\text { The values are } \\
\text { average for two } \\
\text { species on which } \\
\text { the estimates } \\
\text { were made. }\end{array}$ & $\begin{array}{c}\text { Devi and Singh } \\
\text { (2021) }\end{array}$ \\
\hline 2 & Tripura & $\begin{array}{c}\text { tree allometric } \\
\text { equations }\end{array}$ & 24.992 & $\begin{array}{l}\text { The values are } \\
\text { average for eight } \\
\text { species on which } \\
\text { the estimates } \\
\text { were made. }\end{array}$ & $\begin{array}{c}\text { Sarkar et al } \\
(2021)\end{array}$ \\
\hline
\end{tabular}




\begin{tabular}{|c|c|c|c|c|c|}
\hline 3 & Chattisgarh & $\begin{array}{c}\text { tree allometric } \\
\text { equations }\end{array}$ & 3.64 & $\begin{array}{l}\text { The values are } \\
\text { average for two } \\
\text { species on which } \\
\text { the estimates } \\
\text { were made. }\end{array}$ & $\begin{array}{c}\text { Samal et al } \\
(2022)\end{array}$ \\
\hline 4 & Assam & $\begin{array}{c}\text { tree allometric } \\
\text { equations }\end{array}$ & 888 & $\begin{array}{l}\text { The values are } \\
\text { average for } \\
\text { planted forest } \\
\text { and natural } \\
\text { forests. }\end{array}$ & $\begin{array}{c}\text { Gogoi et al } \\
(2021)\end{array}$ \\
\hline 5 & Chattisgarh & $\begin{array}{c}\text { tree allometric } \\
\text { equations }\end{array}$ & $1.5-2.0$ & $\begin{array}{l}\text { Values are for } \\
\text { mixed sal forest. }\end{array}$ & $\begin{array}{c}\text { Raj and Jhariya } \\
(2021)\end{array}$ \\
\hline 6 & Haryana & $\begin{array}{c}\text { tree allometric } \\
\text { equations }\end{array}$ & $3.55-4.35$ & $\begin{array}{c}\text { Yadav et al } \\
(2022)\end{array}$ \\
\hline 7 & Haryana & $\begin{array}{c}\text { tree allometric } \\
\text { equations }\end{array}$ & 4 & $\begin{array}{l}\text { Values } \\
\text { correspond to } \\
\text { only eucalyptus } \\
\text { plantations. }\end{array}$ & $\begin{array}{c}\text { Kumar et al } \\
(2021)\end{array}$ \\
\hline 8 & Chattisgarh & $\begin{array}{c}\text { tree allometric } \\
\text { equations }\end{array}$ & 161.535 & $\begin{array}{l}\text { Values is an } \\
\text { average of two } \\
\text { riparian zones. }\end{array}$ & $\begin{array}{c}\text { Kujur et al } \\
(2021)\end{array}$ \\
\hline
\end{tabular}




\section{References}

Ahuja V (2021) Carbon Bio-capturing System for Environment Conservation In: Pant D, Nadda A K,

Pant K K, Agarwal A K (Eds) Advances in Carbon Capture and Utilisation. Springer, Singapore, pp. 99126. ISBN: 978-981-16-0638-0.

Devi A S, Singh K S(2021) Carbon storage and sequestration potential in aboveground biomass of bamboos in Northeast India. Scientific Reports 11(1): 1-8. https://doi.org/10.1038/s41598-020-80887-w

Gogoi A, Ahirwal J, Sahoo U K (2021) Plant biodiversity and carbon sequestration potential of the planted forest in Brahmaputra flood plains. Journal of Environmental Management 280: 111671. https://doi.org/10.1016/j.jenvman.2020.111671

Khurana N, Goswami N, Sarmah R, Devanshi (2021) Carbon Capture: Innovation for a Green Environment. In: Pant D, Nadda A K, Pant K K, Agarwal A K (Eds) Advances in Carbon Capture and Utilisation. Springer, Singapore, pp. 11 - 31. ISBN: 978-981-16-0638-0

Kujur E, Jhariya M K, Yadav D K, Banerjee A (2021) Biomass, carbon storage and CO2 mitigation potential of two riparian sites of northern Chhattisgarh, India. Environmental Earth Sciences 80(21)1-16. https://doi.org/10.1007/s12665-021-10019-8 
Kumar P et al (2021). Carbon sequestration and soil carbon build-up under eucalyptus plantation in semiarid regions of North-West India. Journal of Sustainable Forestry 40(4): 319-

331.https://doi.org/10.1080/10549811.2020.1749856

Rackley S (2010) Carbon capture and Storage. Elsevier, Oxford. ISBN 978-1-85617-636-1

Raj A, Jhariya M K (2021) Carbon storage, flux and mitigation potential of tropical Sal mixed deciduous forest ecosystem in Chhattisgarh, India. Journal of Environmental Management 293: 112829.

https://doi.org/10.1016/j.jenvman.2021.112829

Raj A, Jhariya M K (2021) Carbon storage, flux and mitigation potential of tropical Sal mixed deciduous forest ecosystem in Chhattisgarh, India. Journal of Environmental Management 293: 112829. https://doi.org/10.1016/j.jenvman.2021.112829

Rawat D, Sati S P, Khanduri V P, Riyal M, Mishra G (2021) Carbon Sequestration Potential of Different Land Use Sectors of Western Himalaya. In: Pant D, Nadda A K, Pant K K, Agarwal A K (Eds) Advances in Carbon Capture and Utilisation. Springer, Singapore, pp. 273-294. ISBN: 978-981-16-0638-0.

Ringrose P (2020) How to Store $\mathrm{CO}_{2}$ Underground: Insights from early-mover CCS Projects .Springer, Switzerland. ISBN 978-3-030-33113-9 
Samal B, Singh L, Jhariya M K (2022) Carbon storage, mitigation and sequestration potential of Haldina cordifolia and Mitragynaparvifolia in tropical dry deciduous environment of Chhattisgarh, India. Ecological Engineering 175: 106490. https://doi.org/10.1016/j.ecoleng.2021.106490

Sarkar P K, Sarkar P, Kumar A, Pala N A, Kumar M (2021). Carbon Storage Potential of a Waterlogged Agroforestry System of Tripura, India. Water, Air, \& Soil Pollution 232(4): 1-13.

https://doi.org/10.1007/s11270-021-05098-z

Vishal, V., Chandra, D., Singh, U., \& Verma, Y. (2021). Understanding initial opportunities and key

challenges for CCUS deployment in India at scale. Resources, Conservation and Recycling, 175, 105829.https://doi.org/10.1016/j.resconrec.2021.105829

Wasewar K (2021) Carbon Dioxide Capture by Ionic Liquids. In: Pant D, Nadda A K, Pant K K, Agarwal A K (Eds) Advances in Carbon Capture and Utilisation. Springer, Singapore, pp. 147 - 194. ISBN: 978981-16-0638-0

Wei Y M et al (2021) A proposed global layout of carbon capture and storage in line with a 2 C climate target. Nature Climate Change 11(2): 112-118. https://doi.org/10.1038/s41558-020-00960-0

Yadav V S, Yadav S S, Gupta S R, Meena R S, Lal R, Sheoran N S, Jhariya M K (2022) Carbon sequestration potential and $\mathrm{CO}_{2}$ fluxes in a tropical forest ecosystem. Ecological Engineering 176: 106541. https://doi.org/10.1016/j.ecoleng.2022.106541 
